INTERNATIONAL MONETARY FUND

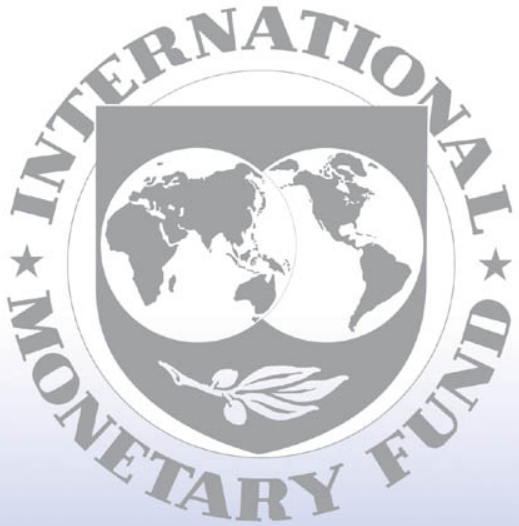

Staff

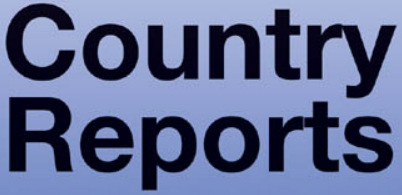




\section{Indonesia: 2009 Article IV Consultation-Staff Report; Staff Statement; Public Information Notice on the Executive Board Discussion; and Statement by the Executive Director for Indonesia}

Under Article IV of the IMF's Articles of Agreement, the IMF holds bilateral discussions with members, usually every year. In the context of the 2009 Article IV consultation with Indonesia, the following documents have been released and are included in this package:

- $\quad$ The staff report for the 2009 Article IV consultation, prepared by a staff team of the IMF, following discussions that ended on June 5, 2009, with the officials of Indonesia on economic developments and policies. Based on information available at the time of these discussions, the staff report was completed on June 30, 2009. The views expressed in the staff report are those of the staff team and do not necessarily reflect the views of the Executive Board of the IMF.

- A staff statement of July 13, 2009, updating information on recent developments.

- $\quad$ A Public Information Notice (PIN) summarizing the views of the Executive Board as expressed during its July 13, 2009 discussion of the staff report that concluded the Article IV consultation.

- $\quad$ A statement by the Executive Director for Indonesia.

The document listed below will be separately released.

\section{Selected Issues Paper}

The policy of publication of staff reports and other documents allows for the deletion of market-sensitive information.

\section{International Monetary Fund Washington, D.C.}


This page intentionally left blank 


\section{INTERNATIONAL MONETARY FUND}

\section{INDONESIA}

\section{Staff Report for the 2009 Article IV Consultation}

Prepared by the Staff Representatives for the 2009 Consultation with Indonesia

Approved by Mahmood Pradhan and Aasim Husain

June 30, 2009

- Consultation and team. The 2009 Article IV consultation discussions with Indonesia were held in Jakarta during May 25-June 5, 2009. The staff team comprised Mr. Rumbaugh (Head), Mmes. Ramakrishnan and Ruiz-Arranz (all APD), Mr. Goyal (SPR), Mr. Baldacci (FAD), and Ms. Gobat (MCM). Mr. Zavadjil (Senior Resident Representative) also participated in the discussions. Mr. Kartikoyono (Advisor, OED) attended the meetings. The team met with Finance Minister Sri Mulyani Indrawati, Bank Indonesia Acting Governor Miranda Goeltom, Minister of Trade Mari Pangestu, Minister of State-owned Enterprises Sofjan Djalil, Minister of Energy and Mineral Resources Purnomo Yusgianotoro, other senior officials, and private sector representatives.

- Context of past surveillance. In recent consultations, the Fund and the authorities have agreed on the broad policy priorities, including improving fiscal space through revenue and expenditure measures, enhancing fiscal management, anchoring inflationary expectations, and maintaining a prudential approach to lending. Constructive dialogue with the authorities is ongoing through technical assistance in fiscal and monetary operations and management. An FSAP is scheduled for later this year, which will inform the 2010 Article IV consultation.

- Exchange rate system. Indonesia has a floating exchange rate regime. Indonesia has also accepted the obligations under Article VIII, Sections 2, 3, and 4, and maintains an exchange system free of restrictions on the making of payments and transfers for current international transactions.

- Economic statistics are broadly adequate for surveillance purposes, although they could be improved in some areas (Annex IV). Indonesia subscribes to the Special Data Dissemination Standard. 
Executive Summary

I. Overview

II. Background

III. Outlook and Risks

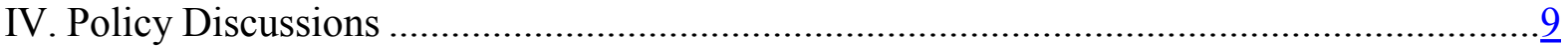

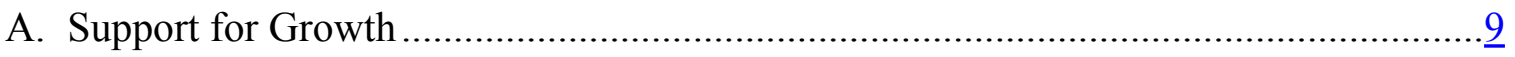

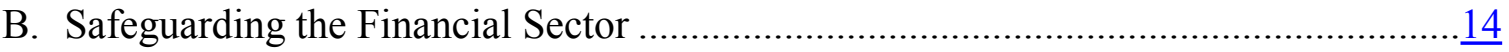

C. Alleviating Balance of Payments Stress …........................................................

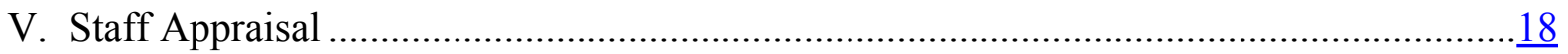

Boxes

1. Comparison of GDP Components with Regional Peers ….......................................... $\underline{8}$

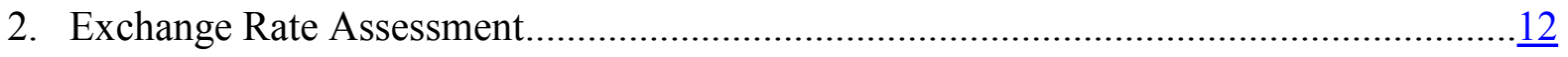

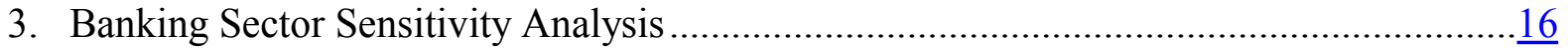

Figures

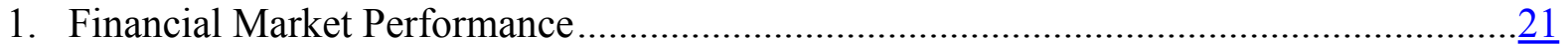

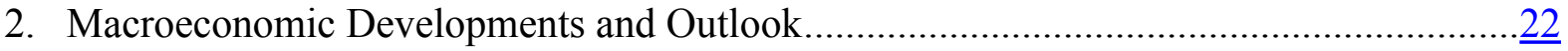

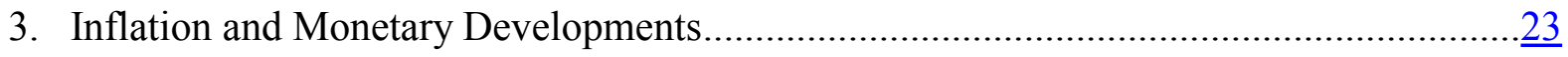

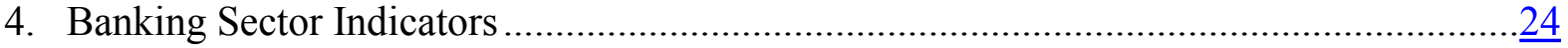

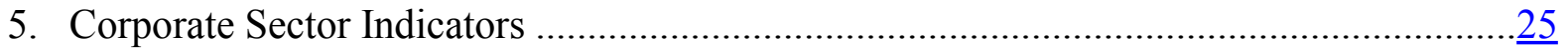

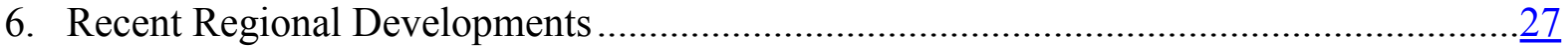

Tables

1. Summary of Financial Sector Interventions ..........................................................

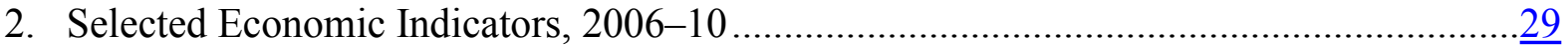

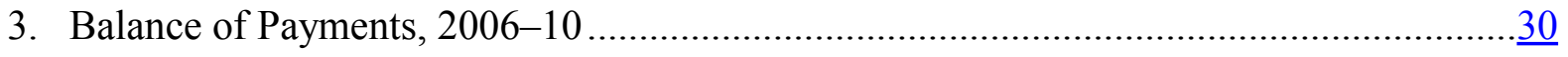

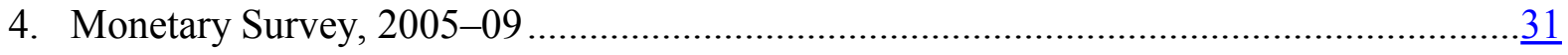

5. Summary of Central Government Operations, 2005-10............................................ 32

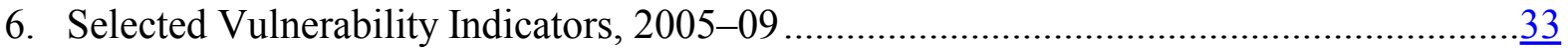

7. Medium-Term Macroeconomic Framework, 2008-14 …...........................................34

Appendices

I. Public and External Debt Sustainability 


\section{EXECUTIVE SUMMARY}

Impact of global financial turmoil: Benefiting from strong initial conditions and timely policy responses, the Indonesian economy has withstood well the recent economic turmoil. Despite the impact on financial markets during the last quarter of 2008, which has mostly been reversed now, the economy has continued to grow albeit at a slower pace. The strength of the economy stems from its greater dependence on domestic consumption rather than exports, unlike many of its regional peers. The economy has also received a big boost in the first quarter from election-related spending which provided strong support for private consumption.

Political background: The Legislative elections were successfully completed in April; the Presidential election is scheduled for July 8, with a run-off on September 8, if needed.

Outlook and risks: Growth in 2009 is expected to decelerate to 3-4 percent, compared with 6 percent in 2008, with growth driven by domestic consumption, although the fiscal stimulus would have to be fully implemented to support demand growth. Weak external conditions and slow credit growth dampened exports and investment in the first half of 2009. However, a return of credit growth and external recovery could support higher investment and exports in the second half of the year. On the downside, if there were another bout of global risk aversion, it could adversely affect external liquidity and growth, potentially leading to reversal of capital inflows, drying up of external credit, and further declines in external and domestic demand.

Monetary and exchange rate policy: The staff and authorities agreed that the monetary easing cycle since December 2008 may soon have run its course with a more cautionary approach appropriate going forward. There is ample stimulus in the pipeline from the interest rate cuts already implemented which, combined with the abundant liquidity in the banking sector, should soon result in higher credit growth. In the medium term, anchoring monetary policy on a well-defined framework would help lower inflation volatility and enhance policy credibility. The exchange rate is broadly in equilibrium and its flexibility has served well as a shock absorber.

Fiscal policy: The growth impact of the 2009 fiscal stimulus depends on the timely execution of the spending measures, especially on infrastructure. For 2010, given the availability of fiscal space and that complete withdrawal of the stimulus could endanger economic recovery, retaining some of the stimulus relative to 2008 would support aggregate demand, with public debt consolidation continuing over the medium term. In this context, the staff advised that there was room for a somewhat higher fiscal deficit for 2010 than currently planned by the authorities.

Banking sector: The banking system has been resilient to the global financial turmoil. Managing credit risk is the key challenge. Smaller banks also remain vulnerable to liquidity risk given their narrow funding options and difficulties with market access during distress. Going forward, improving supervision and encouraging lending consistent with banks' risk management capabilities would help maintain asset quality and enhance public confidence; regulatory forbearance or administrative measures to promote lending should be avoided. The forthcoming FSAP will conduct an in-depth examination of the financial sector and help identify specific areas that need to be strengthened. 


\section{OVERVIEW}

1. The 2009 Article IV consultation occurred against the backdrop of an uncertain global economic climate and an ongoing election cycle.

- Indonesia entered the current global crisis with strong initial conditions. Aided by a generally favorable global economic climate that prevailed prior to the recent crisis, Indonesia's fundamentals were strengthened through sound macroeconomic policy implementation, including prudent debt management and developing a more sound financial sector. Economic growth averaged 6 percent since 2005, fiscal performance was strong, the current account was in surplus, both public and external debt have halved in the last five years to about 30 percent of GDP, and international reserves had risen by $\$ 22$ billion in that period to a comfortable level of more than 150 percent of short-term debt.

- The elections have so far proceeded smoothly. The parliamentary elections held on April 9 were not associated with high market volatility that characterized some previous elections, and market sentiment has subsequently improved. The Presidential election is scheduled for July 8, with a run-off on September 8, if needed.

\section{BACKGROUND}

2. Indonesia's financial markets were adversely impacted by the global financial crisis. As foreshadowed at the time of the last Article IV consultation, Indonesia was especially vulnerable to shifts in investor sentiment. During the last quarter of 2008, various factors affected investor confidence, including falling commodity prices, liquidity problems in some segments of the banking sector, default by a huge conglomerate on its obligations, and general global risk aversion, all of which led to a sharp deterioration in market conditions and a rise in sovereign EMBI spreads to over

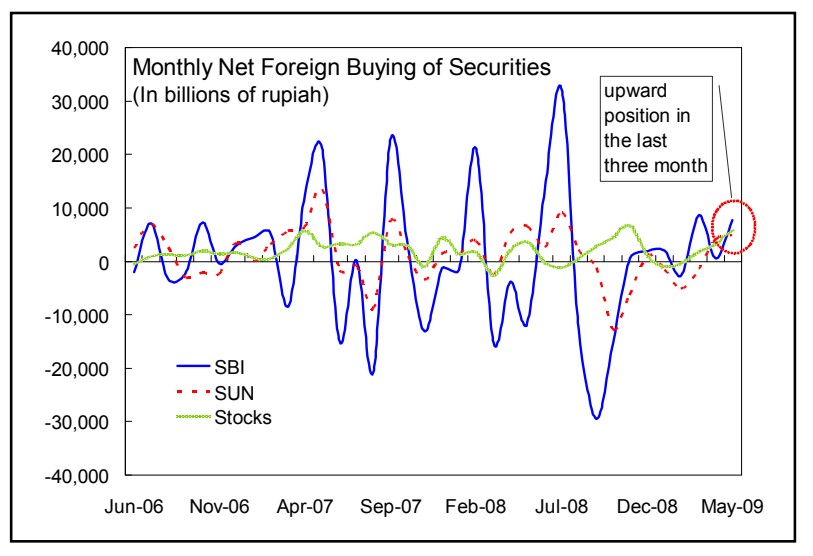
1,200 basis points, much higher than comparable emerging market economies. ${ }^{1}$ Net capital outflows accelerated during September-November, primarily in the form of portfolio outflows as nonresidents reduced their holdings of central bank and government securities by some $\$ 6 \frac{1}{2}$ billion (text chart). The yield on government domestic bonds spiked sharply to as

\footnotetext{
${ }^{1}$ A selected issues paper examines the factors determining Indonesian EMBI spreads.
} 
high as 20 percent in late-October as foreign investors and local commercial banks reduced exposures while market liquidity dried up, resulting in the government cancelling all debt issuances through the end of the year and seeking official external budget contingency financing for $\$ 5 \frac{1}{2}$ billion, as well as temporarily suspending mark-to-market valuation on banks' government bond holdings. The currency depreciated by some 40 percent, and the stock market index declined by a similar amount (Figure 1). These factors contributed to a decline in international reserves by $\$ 10$ billion to $\$ 50$ billion between July and October 2008 .

\section{Despite the initial shock, financial markets have recovered in 2009. Concerns} about corporate rollover risk as well as resident deposit outflows did not materialize. With relatively low vulnerabilities in the corporate and banking sectors arising from their strong balance sheet positions, and high capitalization and profitability of the banking system, the economy was able to absorb the impact of the crisis. Moreover, a series of mitigating measures were taken by the government and Bank Indonesia (BI), including lowering banks' reserve requirements, liquidity injection through repos, expansion of eligible collateral for short-term financing from BI, temporary ban of short-selling, and expansion of deposit insurance coverage. ${ }^{2}$ These factors, combined with the stronger than expected recovery in Q1 of 2009, boosted domestic and foreign investor confidence. Thus, and broadly in line with improvements in other Asian emerging markets, CDS spreads have dropped to around $300 \mathrm{bps}$, the stock market has recovered by 80 percent, and the rupiah has appreciated by about 20 percent as of end-June relative to their lowest points late last year. Capital inflows have also resumed, and reserves have risen to \$58 billion in May 2009.

4. Strong consumption supported the recovery in Q1 of 2009. The Indonesian economy's stronger than expected real GDP growth of 4.4 percent $(y / y)$ made it one of the fastest growing emerging market economies. The recovery was supported by particularly strong private consumption which benefited from a large election-related spending stimulus and, to a lesser extent, tax cuts implemented as part of the fiscal stimulus package; public consumption also grew strongly due to frontloading of one-off salary payments and purchases of goods and services. Investment and exports,

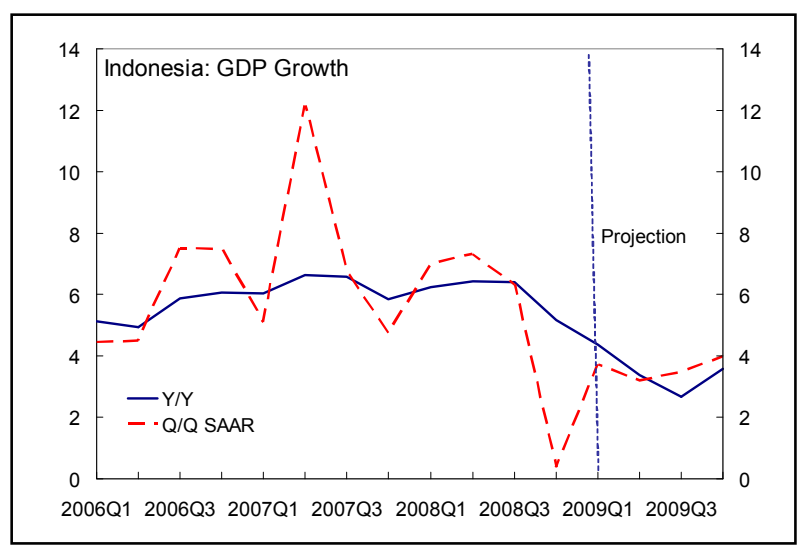
however, declined sharply (q/q, s.a.). The strong recovery in Q1 came at the back of weak

\footnotetext{
${ }^{2}$ Table 1 summarizes the policy measures taken in response to the crisis.
} 
growth in Q4 of 2008 as weak external conditions took their toll and economic activity slowed sharply (Figure 2). This was reflected in both weaker exports and domestic demand. The latest leading indicators - retail sales, motor vehicle sales, and industrial productionsuggest that the economy may have bottomed out on a sequential growth basis. Moreover, consumer confidence is at its highest since January 2005.

\section{External accounts also improved in the first quarter of 2009 after deteriorating} in 2008. The balance of payments surplus in Q1 was $\$ 4$ billion compared with a deficit of $\$ 4.2$ billion in Q4 of 2008. This outcome was supported by a current account surplus of $\$ 1.8$ billion as non-oil imports fell by more than the decline in exports. The decline in non-oil imports reflects a large drop in raw material imports, consistent with the weakness in manufacturing. Commodity exports began to recover as coal prices increased and demand for copper rose. The financial account

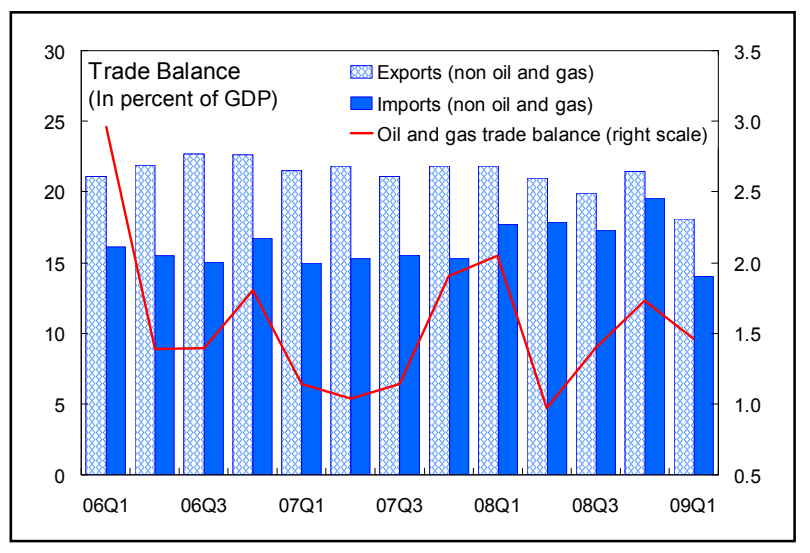
recorded a surplus of $\$ 2.4$ billion largely from demand for sovereign debt securities, after declining by more than $\$ 4$ billion in Q4 of 2008 due to capital outflows from global risk aversion.

\section{The recent monetary stance has kept pace with easing inflationary pressures and} slow domestic demand. BI has been on a monetary-easing cycle since December 2008; the policy rate has been cut by 250 basis points to 7 percent, an historical low. CPI inflation has decelerated rapidly since October 2008: year-to-date inflation through May 2009 is only about 0.1 percent and the annual rate has declined to 6 percent (Figure 3 ). Core inflation, which excludes administered and volatile prices, however, is a bit higher with a year-to-date rate of 1.7 percent. The deceleration follows strong inflationary pressures in 2008 resulting from high commodity prices as well as strong credit growth and domestic demand, which together led to inflation of 11 percent in 2008, well above BI's 4-6 percent target range.

7. Fiscal space for a stimulus package was made possible by solid performance over several years. The government announced a stimulus package for 2009 of about 1 1 $\frac{2}{2}$ percent of GDP to support domestic demand. This deficit expansion follows several years of prudent fiscal management, including primary fiscal surpluses of about 2 percent of GDP per year, that has led to a decline in public debt to 33 percent of GDP. In 2008, the fiscal position was broadly in balance, well above the government's revised budget deficit target of 2 percent of GDP, driven mostly by strong non-oil revenue performance. In Q1 of 2009, a small surplus has been recorded, in line with normal seasonality, but smaller than in 2008 due to tax measures related to the stimulus and some frontloaded spending. 


\section{Banking indicators are generally robust, and the system has proved to be}

resilient. Financial soundness indicators improved in 2008 - profitability rose and the capital base strengthened further as banks retained a larger share of their profits and increased capital (Figure 4). Overall liquidity conditions have improved since end-2008, with overnight interbank market rates, loan-deposit ratios, and banks' overall excess reserve holdings with BI back to pre-crisis levels. Credit growth has slowed on a monthly basis since December 2008, although this is not entirely unexpected after a prolonged period of rapid growth and in light of the more uncertain environment.

\section{The corporate sector has thus far withstood reduced access to foreign funding.} Indonesian companies have over time reduced their vulnerabilities, including lowering leverage ratios, raising profitability margins, and reducing exposure to external liabilities. However, the corporate sector experienced some distress at the height of last year's crisis as indicated by the jump in the estimated corporate default probabilities for listed companies. More recent data indicate declining default probabilities, albeit still higher than the pre-crisis level (Figures 5 and 6).

\section{OUTLOOK AND RISKS}

10. Economic growth is expected to slow considerably in 2009 , although it is likely to remain among the highest in the region. Unlike other export-dependent Asian economies, the strength of private consumption in Indonesia is expected to keep growth positive, with 2009 GDP growth projected to be 3-4 percent (see Box 1 for a comparison with other countries). However, the weak external environment and a cautious sentiment in some sectors of the domestic economy are depressing exports and investment. While there are signs that the export decline may be bottoming out, its sustained recovery depends on whether some of the higher exports (e.g., copper and coal) is temporary due to inventory rebuilding or reflecting a

\begin{tabular}{|c|c|c|c|c|c|c|}
\hline \multicolumn{7}{|c|}{ Indonesia: Medium-Term Macrœeconomic Framework, 2007-14 } \\
\hline & 2007 & 2008 & 2009 & 2010 & 2013 & 2014 \\
\hline & \multicolumn{6}{|c|}{ (Percentage change) } \\
\hline Real GDP growth & 6.3 & 6.1 & 3.5 & 4.5 & 6.0 & 6.3 \\
\hline Domestic demand & 4.1 & 7.7 & 4.9 & 5.5 & 6.2 & 6.5 \\
\hline Net exports $1 /$ & 0.6 & 0.7 & -0.9 & -0.5 & 0.3 & 0.3 \\
\hline CPI inflation (end period) & 5.6 & 11.1 & 5.0 & 5.5 & 3.8 & 3.6 \\
\hline Saving and investment & \multicolumn{6}{|c|}{ (In perœent of GDP) } \\
\hline Gross investment & 25.0 & 27.6 & 26.9 & 27.7 & 29.0 & 29.5 \\
\hline Gross national saving & 27.4 & 27.8 & 27.2 & 27.2 & 28.1 & 28.4 \\
\hline Current account balance & 2.4 & 0.1 & 0.3 & -0.4 & -0.9 & -1.0 \\
\hline Central government balance & -1.2 & -0.2 & -2.6 & -2.0 & -1.6 & -1.5 \\
\hline Central government debt & 35.1 & 32.3 & 31.1 & 31.0 & 29.1 & 28.3 \\
\hline
\end{tabular}
sustained recovery in underlying demand. Headline inflation is likely to drop to 5 percent by end-2009, although core inflation may be higher at about $6 \frac{1}{2}$ percent. The external current and financial accounts are likely to continue to be in slight surplus. Staff's growth outlook 


\section{Box 1. Comparison of GDP Components with Regional Peers}

- Indonesia's dependence on exports is among the lowest relative to its regional peers. Over 2006-08, the average exports of goods and services - at less than 50 percent of GDP — was more closely aligned with India. Indonesia is less vulnerable than most of the other countries to the strong headwinds from slowing external demand, especially when remittance inflows are taken into account. Moreover, Indonesia's export destinations and composition are relatively more diversified; thus, a slump in any single region is unlikely to have a large impact on Indonesia's overall exports.

- Indonesia's domestic demand is one of the highest in the group. Total domestic demand is almost 90 percent of GDP compared to 70-80 percent in some of the other countries. In particular, consumption expenditures (private and public) are about 67 percent, benefiting from the large domestic market base.

- This is not to say that Indonesia will be immune to the weak external demand. Like other countries, Indonesia's exports have been falling in recent months. However, the impact of the external weakness on growth may be less than its more export-dependent peers; like in India, Indonesia's domestic demand growth is expected to buffer the decline and keep GDP growth positive.

\section{Comparison of External and Domestic Factors in GDP}

(Averages 2006-08)
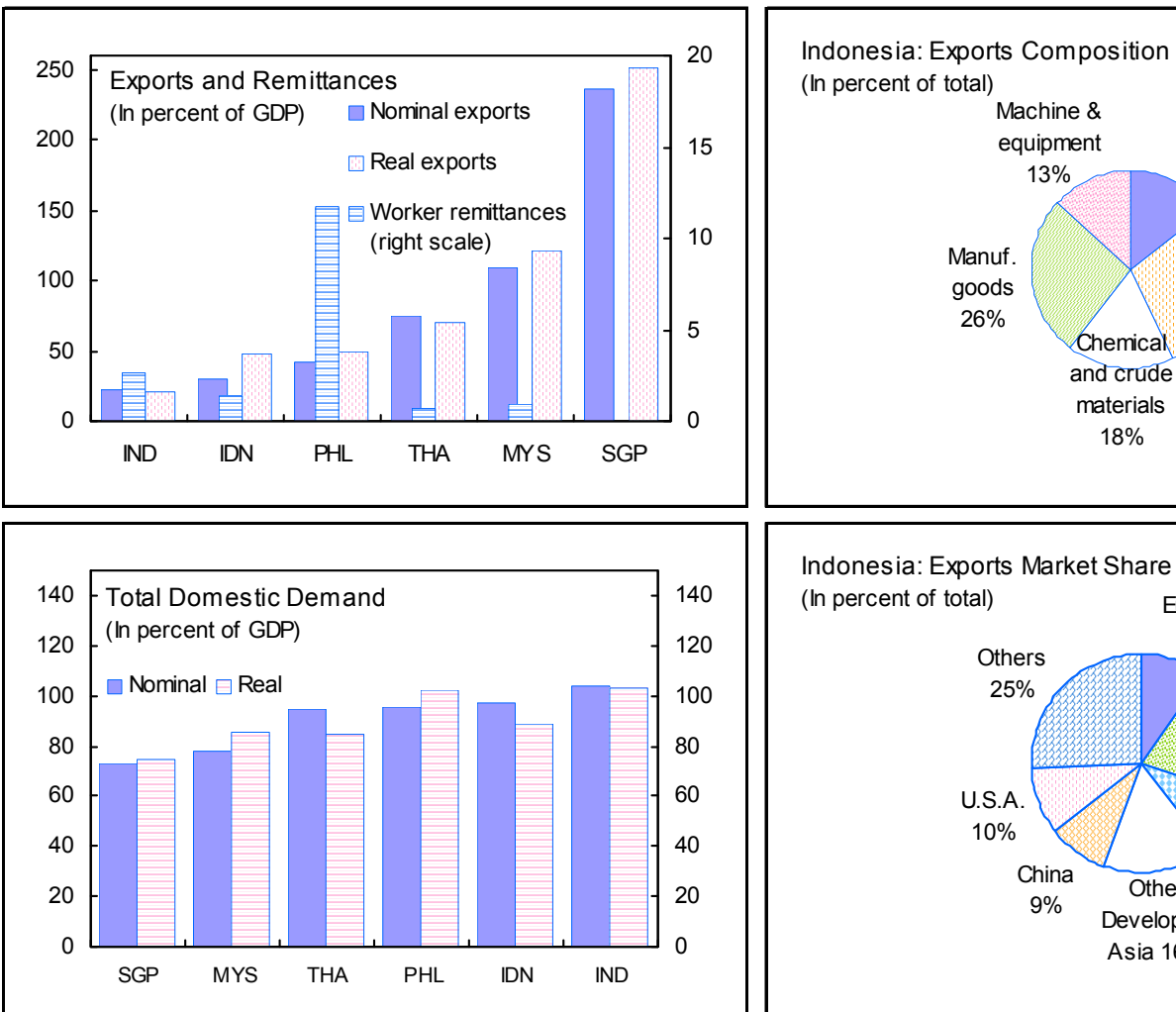

Indonesia: Exports Market Share

(In percent of total)

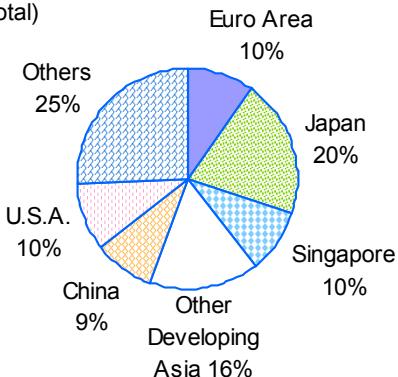

Sources: IMF, World Economic Outlook; IMF, Direction of Trade Statistics; CEIC Data Co., Ltd.; and IMF staff calculations. 
is broadly in line with BI's assessment but lower than the government's projected growth of $4-4 \frac{1}{2}$ percent which stems mostly from an expectation of stronger consumption growth. Despite the relatively positive outlook, the authorities remain concerned about the implications of the uncertain global and regional recovery on Indonesia, and the potential for further volatility in financial markets.

\section{Key near term risks relate to the underlying strength of both domestic and} external demand. In particular, private consumption - which is the largest part of GDPmay need policy support to maintain growth. On the upside, the stimulus effects of the recent monetary easing may be stronger than expected in supporting domestic demand. A stronger than expected external recovery could also provide an added boost. On the downside, however, another bout of global risk aversion or fall in commodity prices could impact external liquidity and growth via reversal in capital inflows, tightening credit markets, and fall in exports as well as domestic demand. An additional risk is that the budgeted spending plans are not executed in time or are insufficient to replace the first quarter's election-related spending stimulus.

12. In the medium term, potential growth is expected to be gradually restored. While GDP growth in 2010 is likely to remain below potential (about 4-5 percent), as the global economy gradually improves, export growth should slowly recover thereafter. Domestic demand should also grow strongly, especially as investment gains momentum, which would lead to higher imports. Higher infrastructure investment over the medium term, would contribute to greater efficiency, increase productivity, promote rural development, and help achieve higher potential growth. Maintaining an open approach to external trade would also support the economy's long-term competitiveness. Reducing inflation to 3-4 percent would enhance overall policy credibility and lower volatility.

\section{Policy Discussions}

13. Discussions focused on three main policy challenges: (i) the policy mix to support growth; (ii) protecting the safety and stability of the financial sector; and (iii) alleviating potential stresses to the balance of payments, particularly if there is a significant worsening in global risk aversion and/or tightening in external liquidity conditions.

\section{A. Support for Growth}

\section{Monetary and Exchange Rate Policy}

\section{The authorities agreed with staff that the monetary easing cycle may soon have}

run its course. The reduction in the policy rate by 250 basis points since December 2008 was appropriate and in line with the declining inflation and slowing domestic demand. Going forward, there is some concern about the recent increases in commodity prices-which have a large impact on domestic inflation - as well as the prospects for a stronger economic 
recovery. In this respect, despite the currently benign inflationary pressures and the recent exchange rate appreciation, a cautionary approach to any further easing would be appropriate given the ample monetary stimulus already in the pipeline, the abundant liquidity in the banking system, and until the direction of the economy can be better gauged. Also, given the long lags in monetary transmission (see below), the impact of the recent rate cuts on the real economy may spill over to a period when stronger recovery is beginning to take hold, leading to high credit growth and inflationary expectations, and the need to

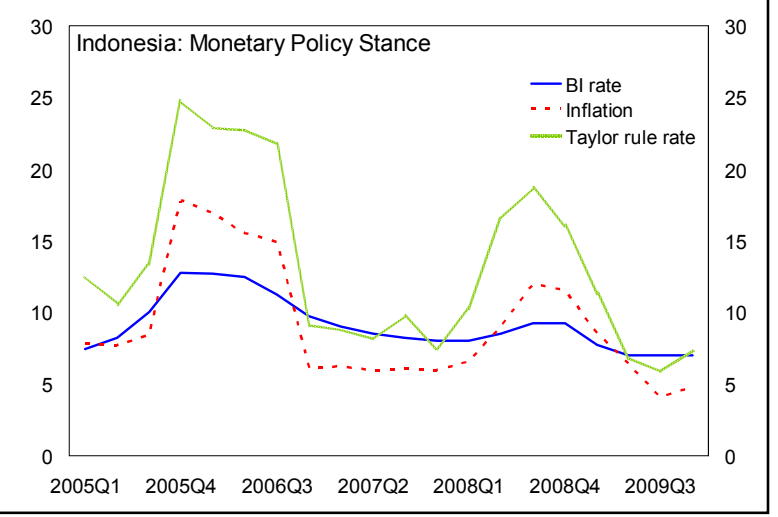
quickly reverse course. In addition, an estimated Taylor rule indicates BI's policy stance has generally tended to have an expansionary bias over time, suggesting that a more cautious stance would be appropriate now. ${ }^{3}$ Finally, any worsening in global risk aversion and external liquidity risks would also justify a cautious monetary stance so as not to jeopardize capital flows and the international reserve position.

\section{Monetary transmission in Indonesia has been slow, but credit growth is likely to}

turn positive in the second half of the year. The authorities and private commentators were concerned about the slow response of the lending rate to the recent policy rate cuts, as well as the stagnation of credit growth. While deposit rates - particularly the minimum guaranteed rate - have normally responded swiftly to policy rate changes, the lending rate has historically responded more slowly and less fully to policy rate changes. Indeed, some of the major banks are reportedly just beginning to lower their lending rates. That said, banks have been more cautious in their lending in recent months, particularly to SMEs, due to the perceived credit risk as well as the need to build liquidity buffers given the uncertain economic climate. Also, some smaller to mid-sized banks have had to offer higher deposit rates to restore liquidity positions,

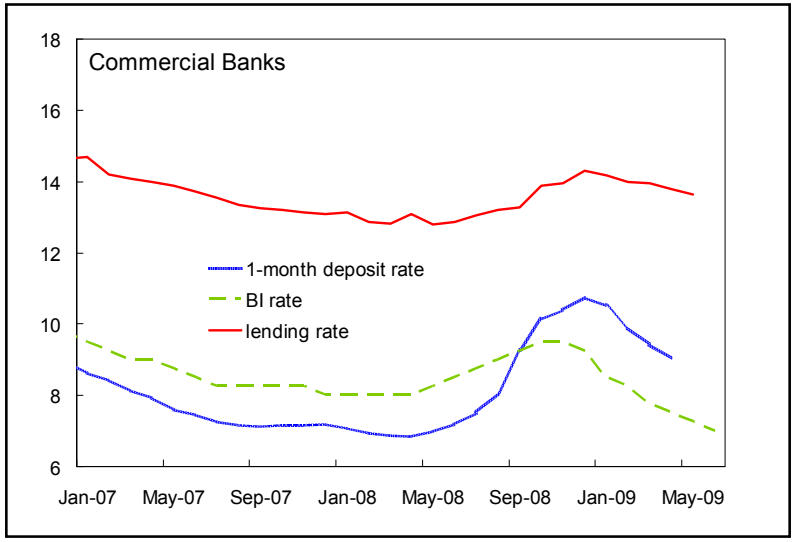
reducing their ability to lower lending rates much further in order to maintain margins. On balance, staff considers that with the prevailing strong confidence, sufficient liquidity in the

\footnotetext{
${ }^{3}$ The estimated Taylor rule assumes deviations from an inflation objective of 5 percent and potential growth rates as derived from an $\mathrm{H}-\mathrm{P}$ filter.
} 
banking system, and completion of transmission lags, credit growth is likely in the second half of 2009, albeit at a lower pace than in the last two years.

\section{Anchoring monetary policy on a well-defined policy framework would enhance} policy credibility. Although BI adopted an inflation targeting framework in 2005, its pragmatic approach to monetary policy - by which it balances exchange rate stability, inflation, and growth trade-offs - has kept inflation from rising to excessively high levels, but has not managed to bring it down to partner country rates. Staff analysis indicates that this may have contributed to higher economic costs relative to comparator countries in terms of wider bond spreads and greater market volatility. Moreover, the multiplicity of objectives may have also contributed to higher inflation volatility. Concerted efforts - based on a more credible and objective inflation targeting framework - to consistently lower inflation and guide inflationary expectations toward a medium-term target range of 3-4 percent would enhance policy credibility and lower economic costs.

\section{Exchange rate flexibility has served as an important shock absorber for} shielding the real economy from volatile capital flows. As evidenced in recent months, the flexibility of the currency has helped absorb large external shocks, while preserving domestic stability. Based on the different approaches of the CGER methodology, the current rupiah exchange rate is assessed to be broadly in equilibrium (Box 2). The authorities agreed that reserve buffers could continue to be built up gradually in the near term, with intervention largely directed at reducing volatility.

\section{Fiscal Policy}

\section{The fiscal stimulus package for 2009 was appropriate to support weaker}

domestic demand. With the economy quickly decelerating, the tax measures in the stimulus had an immediate impact on private consumption. The new spending measures - amounting to about 20 percent of the stimulus package (mostly on infrastructure projects) - are expected to support demand in the second half of the year. The overall budget deficit is estimated to reach 2.6 percent of GDP in 2009, slightly above the authorities' revised budget reflecting modestly weaker non-energy revenue collection as well as higher energy subsidies. Frontloaded domestic and foreign currency bond issuances - more than two-thirds of gross financing needs were secured in the first six months - and the expected sustained demand for sovereign paper in the remainder of the year have reduced budget financing risks. Despite the wider fiscal deficit, the public debt-to-GDP ratio is expected to decline further to 31 percent of GDP in 2009 reflecting slower but still positive growth and exchange rate appreciation.

19. Better budget execution is key to an effective fiscal stimulus. Staff stressed the need to implement the spending program, particularly given the past record of under execution (especially in capital spending) and back loaded spending, as reflected in 


\section{Box 2. Exchange Rate Assessment}

Recent developments. The rupiah has recovered much of the loss experienced during the market turmoil of late 2008 and early 2009. It depreciated from Rp 9,200 per dollar in early September 2008 to nearly Rp 13,000 per dollar in late November. It has since recovered to about Rp 10,000 per dollar in early June. The real effective exchange rate (REER) has also recovered since the first quarter.

Export performance. Indonesia's export market share in global trade increased in 2008, largely on the back of high commodity prices. The decline in commodity prices and compression in exports globally in the last quarter of 2008 and the first quarter of 2009 resulted in a decline in Indonesia's exports-by 7 percent $y / y$ in 2008 Q4 and 30 percent $y / y$ in 2009 Q1, though these reflect the broader global recession rather than Indonesia's exchange rate valuation.

CGER estimates. Using the IMF's Consultative Group on Exchange Rate Issues (CGER) approach, Indonesia's REER is assessed to be broadly in line with equilibrium.

- The macroeconomic balance (MB) approach yields a modest overvaluation of about 6 percent, with the current account norm estimated at 0 percent of GDP, close to the underlying current account deficit of close to about $3 / 4$ percent of GDP.

- The external sustainability (ES) approach, on the other hand, points to an undervaluation of about

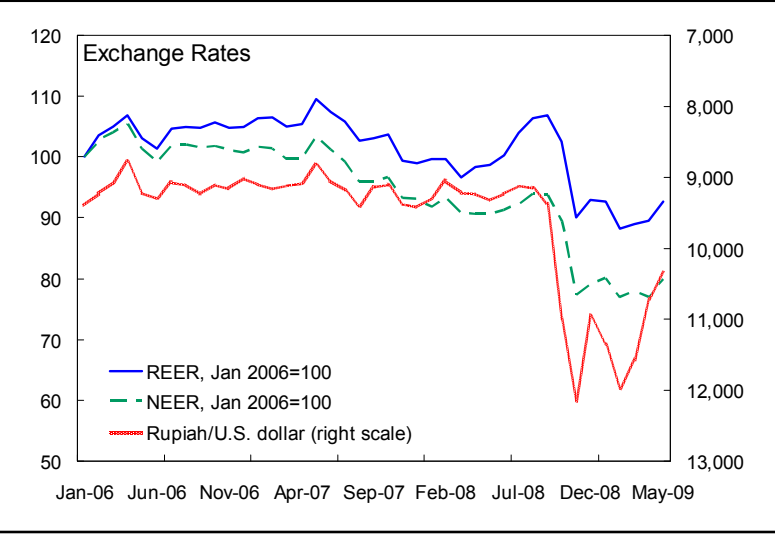
6 percent: the current account deficit needed to stabilize the net foreign asset to GDP ratio at end 2008 is about 13/4 percent of GDP, whereas the medium-term current account deficit is about 1 percent of GDP.

- The equilibrium real exchange rate (ERER) approach suggests an undervaluation of nearly 20 percent: the equilibrium real rate depreciated modestly owing to weaker terms of trade, but the REER depreciated by more. The inclusion of a long pre-crisis period in the sample and the assumption of zero misalignment over the sample in this approach, however, suggests that the estimated equilibrium real rate is biased upward. Caution is needed, therefore, in interpreting this approach.

Overall assessment. The CGER assessment for Indonesia, thus, is 20 below and 5 above equilibrium. However, the REER has appreciated by almost 5 percent from the CGER reference date of March 2009, which leads to a range of 15 below to 11 above, suggesting the REER is now broadly in equilibrium. A similar result is obtained when replicating the CGER methodology for a broader sample of countries and a longer time period, with added explanatory variables. Using WEO data as of April, this robustness exercise yields an undervaluation of 2.1 percent according to the $\mathrm{MB}$ approach (a CA norm of -1.4 percent versus a medium-term projected deficit of 1 percent of GDP), 8.4 percent according to the ES approach, and 6.5 percent according to the ERER approach. The results, therefore, point to an undervaluation of about 6 percent as of April. However, once again, with the noted recent appreciation of the REER, the exchange rate is assessed to be in line with equilibrium. 
the buildup of government deposits at BI during the year. Despite efforts to expedite disbursements, only 20 percent of the revised budget has been disbursed (marginally up from 19 percent in 2008) during the first five months of 2009. The tax components of the stimulus package were implemented promptly, but delays have persisted in capital project execution. While agreeing that budget execution is critical, the

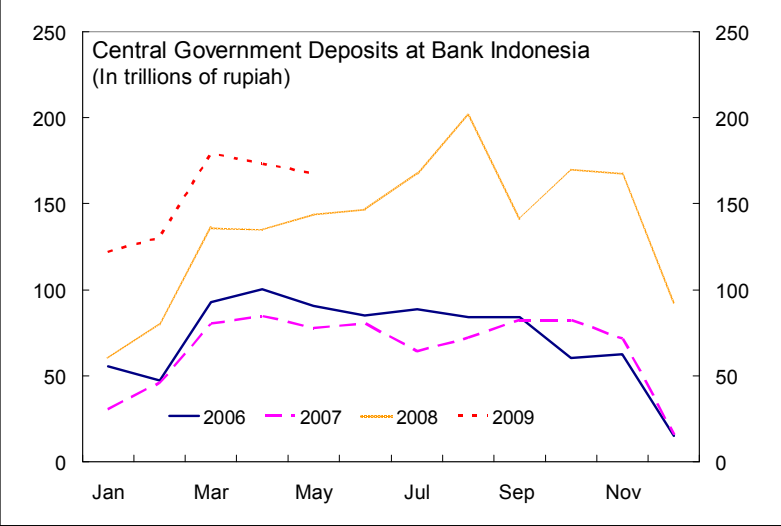
authorities were confident that the stimulus package would be fully implemented by the end of the year. They noted that several measures have been taken to improve execution and flexibility, including simpler procedures for budget implementation (such as the rapid appointment of budget officials, and simplifying documentation and budget processes), closely monitoring budget execution in local treasury offices with the establishment of a high-level central monitoring committee, and expanding the scope for reallocating funds within budget categories.

\section{A supportive fiscal stance in $\mathbf{2 0 1 0}$ would help avoid endangering the economic} recovery path. The authorities' current deficit target of $1 \frac{1}{2}$ percent of GDP for 2010 includes about $1 / 2$ percent of GDP in stimulus measures (mostly further permanent corporate income tax rate cuts). This deficit, however, implies a withdrawal of half the stimulus relative to the pre-crisis position. As the output gap is expected to widen in 2010 , and in the absence of much more room for further monetary easing, it was agreed that fiscal policy would have to play a more supportive role to sustain the

\begin{tabular}{|c|c|c|c|c|c|c|c|c|}
\hline \multicolumn{9}{|c|}{$\begin{array}{l}\text { Indonesia: Fiscal Balance Indicators } \\
\text { (In percent of GDP) }\end{array}$} \\
\hline \multirow[b]{2}{*}{ Fiscal Balance } & \multirow[b]{2}{*}{2007} & \multirow[b]{2}{*}{2008} & \multirow[b]{2}{*}{2009} & \multirow[b]{2}{*}{2010} & \multicolumn{2}{|c|}{$\begin{array}{c}\text { Change from } \\
2008 \\
\end{array}$} & \multicolumn{2}{|c|}{$\begin{array}{l}\text { Change from } \\
\text { Previous Year }\end{array}$} \\
\hline & & & & & 2009 & 2010 & 2009 & 2010 \\
\hline Overall fiscal balance & -1.2 & -0.2 & -2.6 & -2.0 & -2.5 & -1.8 & -2.5 & 0.7 \\
\hline Non-oil fiscal balance $1 /$ & -3.0 & -1.9 & -4.3 & -3.9 & -2.4 & -2.0 & -2.4 & 0.4 \\
\hline Non-oil primary fiscal balance $1 /$ & -1.0 & -0.2 & -2.5 & -2.2 & -2.3 & -2.0 & -2.3 & 0.3 \\
\hline Structural balance & -1.4 & -0.4 & -2.6 & -1.8 & -2.2 & -1.4 & -2.2 & 0.8 \\
\hline Structural non-oil balance $1 /$ & -3.1 & -2.1 & -4.3 & -3.8 & -2.2 & -1.6 & -2.2 & 0.6 \\
\hline Structural non-oil primary balance $1 /$ & -1.1 & -0.4 & -2.5 & -2.1 & -2.1 & -1.7 & -2.1 & 0.4 \\
\hline
\end{tabular}
economic recovery.

Thus, staff noted that a deficit close to 2 percent of GDP could be achieved in light of expected demand for government paper and projected external financing. It would also provide room for additional spending on needed infrastructure areas, such as transportation, ports, water systems and for strengthening the social safety net, without jeopardizing 
medium-term public debt consolidation. ${ }^{4}$ The authorities noted that their ability to provide additional stimulus would depend on the overall risk appetite of the market to meet financing needs. They also noted that their 2010 fiscal targets may be revised once the new government takes office in October 2009.

\section{Continued reforms to strengthen the fiscal framework would provide scope for} more public investment. Several structural reforms have already been undertaken or are ongoing, including the establishment of a consolidated Treasury Single Account (TSA), remuneration of government deposits at $\mathrm{BI}$, and strengthening cash management. Further progress with the following fiscal reforms would enhance budget flexibility and improve public resource management, which could help lower bond yields: (i) reducing energy subsidies and expanding transfers programs and social services for the poor; (ii) raising non-commodity tax revenue ratios by broadening the consumption tax base and continuing tax administration reforms to strengthen arrears collection, taxpayer registration, customized taxpayers services, and audit functions; (iii) anchoring fiscal policies within a medium-term budget framework to ensure adequate fiscal space; (iv) coordinating with line ministries to strengthen budget execution, including at the sub-national government level; and (v) linking cash and debt management strategies to support capital market access and efficient deficit financing. Such measures would also improve the countercyclical role of fiscal policy. ${ }^{5}$ Noting the critical mass of fiscal reforms already underway, the authorities stressed that they would continue on this path in the period ahead.

\section{B. Safeguarding the Financial Sector}

\section{The Indonesian banking sector proved resilient to the effects of the global}

financial turmoil. Aided by strong capital positions and supportive policy measures, banks weathered well the difficult operating environment in the second half of 2008 and early 2009. Indeed, banking performance in 2008 was among the strongest in the region and among emerging markets. Banks reported higher average profitability and capital, helped by continued robust loan growth and large net interest margins. Asset quality remained steady in 2008, although NPLs have inched up in the first four months of 2009 to above 4 percent. The average loan loss ratio of over 100 percent suggests more than adequate loss coverage.

\footnotetext{
${ }^{4}$ Public debt would gradually fall below 30 percent by 2012 . This reflects a return to a positive primary fiscal balance after 2010, reflecting stronger non-oil revenue collection from ongoing tax administration reforms and lower transfers to regional governments in line with their own revenue generation capacity. In the medium term, the debt outlook remains favorable, even under various adverse scenarios (Appendix I).

${ }^{5}$ A selected issues paper examines this issue in detail.
} 
That said, the global crisis did not go unmarked: some small banks, accounting for less than $1 / 2$ percent of total banking assets, have run into trouble since the onset of the crisis. ${ }^{6}$

\section{Sensitivity analysis indicates that the banking sector is generally resilient to a}

range of adverse shocks. Banks are most vulnerable to a sharp deterioration in credit quality and less exposed at this stage to market risk given the underlying shifts in their portfolios (Box 3). The latter is primarily because system-wide banks have a positive net open foreign exchange position as of end-March while regulations restrict their exposure to equities in their trading book. In addition, banks have lowered their holdings of government securities in their trading book. These results and the analysis are, however, preliminary. The forthcoming FSAP will examine the soundness of the banking sector in greater depth, including through a comprehensive stress testing framework.

\section{Despite this resilience, the authorities agreed that risks remain and safeguarding} financial stability is a top priority. NPLs may rise further if corporate distress escalates, pressuring banks' profit margins. ${ }^{7}$ That said, the large banks are generally healthy because of their larger capital and liquidity cushion to withstand further shocks. ${ }^{8}$ The authorities are more concerned about the large number of small and some mid-sized banks, which account for less than 10 percent of banking assets. These banks are more exposed to liquidity risk given their narrow funding base and difficulties accessing the interbank market in times of stress. ${ }^{9}$ Thus, early and quick action on any emerging problems, including liquidity for solvent smaller banks, would be important in helping safeguard banking sector stability. In this regard, the new Financial Safety Net law will enhance the legal framework for bank resolution, enable quick decision-making, and improve institutional coordination for

\footnotetext{
${ }^{6}$ In November 2008, the government recapitalized Bank Century as its liquidity problems mounted and it breached the minimum reserve requirement, and in 2009, Bank IFI was liquidated. More recently, one rural bank was also liquidated.

${ }^{7}$ Indonesian corporates are seen as somewhat more vulnerable to a profit shock than regional peers, according to a study in the May 2009 Asia and Pacific Regional Economic Outlook, because a larger number of Indonesian firms were close to the distress level where cash flows are insufficient to cover the interest on debt at end-2007.

${ }^{8}$ The top 16 banks account for 70 percent of banking assets.

${ }^{9}$ Interest rate risks is more accentuated for the smaller and mid-sized banks as many fund their longer-term assets through short-term funding, mainly more costly time deposits and typically at fixed rates. According to BI a number also experienced deposit outflows during the crisis in late 2008, and many were forced to offer higher deposit rates in order to maintain existing customers.
} 


\section{Box 3. Banking Sector Sensitivity Analysis}

Managing credit risks is a key challenge. Loans account for about 80 percent of banking assets. Loan quality is expected to deteriorate in sectors that have been more affected by the global slowdown (e.g., steel, textile and trade) as well as in some areas of consumer credit such as unsecured credit card debt. The latter still accounts for a small share of total loans. Indonesian banks' exposure to special mention loans (mainly unclassified loans overdue up to 90 days), which account for about 6-7 percent of total loans, remains quite high. Typically, 60 percent of these loans are downgraded to nonperforming status. Restructured loans have also increased in recent months from 2 percent at end-2008 to 2.7 percent at end-February. These risks along with slower loan growth are expected to add pressure to banks' profit margins this year.

To assess the impact of these risks, staff and BI ran sensitivity tests to examine their impact on individual banks' regulatory capital. All 124 banks were covered. Several scenarios were chosen that are more extreme than staff's baseline estimates to test for systemic weakness. The first shock examined the impact of a doubling of NPLs from current levels (end-March 2009), applying historical default rates from special mention to substandard (60 percent) to all other loan categories, and existing provisioning requirements while disregarding collateral. The impact on capital by applying a more conservative loss rate (50 percent) to all new NPLs was also examined. The analysis allowed for some mitigating factors, such as allowing for half of reported first quarter March profits and excess provision as buffer against higher provisioning costs. The analysis also examined the direct balance sheet impact from a 30 percent loss in the value of the rupiah and government bond prices.

The sensitivity analysis found that even a doubling in NPLs would not undermine the soundness of the banking system. The system-wide capital adequacy ratio (CAR) would decline by two percentage points from 19 percent to 17 percent. Assuming a loss rate of 50 percent on all new NPLs does not change the results much, with CAR declining by 1.2 percentage points. In total, four out of 124 commercial banks - accounting for $2 \frac{1}{2}$ percent of banking sector assets — would become undercapitalized and fall below the 8 percent regulatory minimum.

The analysis also shows Indonesian banks are at this stage less exposed to market risk. A deprecation of the rupiah by 30 percent and a decline in government bond prices of 30 percent affect banks marginally with the system-wide CAR falling by only 0.3 percentage points. No bank would be undercapitalized. Banks' positive net open foreign exchange position of 2.6 percent of capital as of end-March 2009 buffers them against a rupiah depreciation. While government bonds account for 12 percent of banking assets, just over 7 percent of this is held in the trading account. The extent of market risk was reduced in late-2008 when, in response to the crisis, regulators allowed banks to shift part of their government securities which were held in available-for-sales to hold-to-maturity, and at fair value rather than at market value. Vulnerability to this exposure could change with the adoption of the IFRS in 2010, as banks' rebuild their trading position, or if there is volatility in the government securities market.

These results and the analysis are preliminary. The upcoming FSAP will examine the soundness of the banking sector in greater depth, including through a comprehensive stress testing framework which will include both a top-down and bottom-up approach and assess banks' vulnerabilities to a range of tail risk shocks, including liquidity risk. ${ }^{1}$

${ }^{1}$ A stress testing TA mission took place in parallel to the Article IV mission to help BI strengthen its credit risk-modeling framework. 
crisis management. The draft law is being discussed in Parliament and its approval would support a strengthened framework going forward. Also, while the deposit insurance scheme (LPS) is fully backed by the government, increased funding to reach its reserve ratio target of $2 \frac{1}{2}$ percent of deposits would enable quick action when needed.

\section{BI agreed that there is scope for strengthening the supervisory framework. In} particular, building on recent progress, BI could continue development of its regulation and supervision capacity to bolster its early warning and bank resolution mechanisms. ${ }^{10}$ Staff also emphasized that supervisors examine banks' implementation of regulations on early restructuring of performing loans to ensure that such restructuring aims to restore the debtor's repayment capacity in full, including its ability to repay the principal. Where this is not assured, such loans could be downgraded to NPL status. BI also agreed that collecting supervisory information on repeatedly restructured loans and restructured loans that migrate to NPL status could be a way to better monitor asset quality and detect any potential problems of "evergreening." Overall, banks have done a good job in restoring health to their balance sheets. Going forward, their loan expansion should be in line with their risk management capabilities and administrative measures or regulatory forbearance to promote lending should be avoided. Staff welcomed the planned launch of the International Financial Reporting Standards in early-2010, as this would further strengthen banks' provisioning practices and bring greater clarity to the valuation of their security holdings.

\section{Alleviating Balance of Payments Stress}

\section{Indonesia has thus far successfully} secured external financing. The bulk of the \$24 billion gross external financing need for 2009 is related to private sector debt obligations, which have been generally successfully rolled over or repaid so far this year. ${ }^{11}$ The balance of payments, however, has been in surplus largely from public sector inflows as the government has effectively secured external funding, including $\$ 3$ billion from an international bond placement in March, and an additional $\$ 650$ million in April from a global sukuk (Islamic bond), which have contributed to an increase in international

\begin{tabular}{|c|c|c|c|}
\hline & Q2 & Q3 & Q4 \\
\hline \multicolumn{4}{|l|}{ Principal payments } \\
\hline Government & 2,276 & 1,051 & 2,332 \\
\hline Banks & 1,534 & 527 & 390 \\
\hline Nonbank private sector & 3,706 & 2,546 & 3,357 \\
\hline Total & 7,516 & 4,123 & 6,078 \\
\hline \multicolumn{4}{|l|}{ Interest payments } \\
\hline Government & 880 & 735 & 919 \\
\hline Banks & 27 & 10 & 29 \\
\hline Nonbank private sector & 465 & 271 & 601 \\
\hline Total & 1,372 & 1,017 & 1,549 \\
\hline
\end{tabular}

Source: Bank Indonesia.

1/ Excludes $\$ 6.38$ billion of debt in standstill (i.e., debt being renegotiated) and $\$ 6.44 \mathrm{~b}$ of primarily nonresident deposits.

\footnotetext{
${ }^{10}$ The BI law mandates that a financial supervision agency be established by end-2010.

${ }^{11}$ This excludes about $\$ 61 / 2$ billion of debt being renegotiated and $\$ 61 / 2$ billion of nonresident deposits.
} 
reserves by nearly $\$ 7$ billion in the first five months of the year. The government has also secured a contingency package for $\$ 5 \frac{1}{2}$ billion in budget support with the World Bank, AsDB, Japan, and Australia, which includes Japan's guarantee of a samurai bond issuance scheduled for later this year, and additional external swap and credit lines. ${ }^{12}$

\section{The current level of international reserves is adequate, although a somewhat larger buffer could help ease pressures in case of another major bout of risk aversion.} Given the current global economic uncertainties, there are still some lingering concerns about worsening external liquidity risks as a result of global capital market and commodity price developments. Specifically, balance of payments pressures could materialize quickly if another round of global risk aversion - say, on the scale of what occurred in 2008significantly undermines market confidence and disrupts capital flows, making international reserves and the external position vulnerable. For example, if risk aversion rises, private capital inflows could decline, foreign holdings of government bonds and central bank bills could be withdrawn (as in the last quarter of 2008), or some deposits could potentially take flight. The current reserve level leaves a relatively small cushion to face a major external shock, and building a somewhat larger buffer, while maintaining a flexible exchange rate policy, would be desirable to further bolster market confidence. ${ }^{13}$ Indeed, countries with access to large buffers relative to their financing needs did not see their spreads rise as much during the crisis.

\section{Staff ApPraisal}

\section{Benefiting from strong initial conditions and effective policy action, Indonesia} has thus far withstood well the global financial crisis. After enduring substantial market pressures during the last quarter of 2008, market confidence has returned and recent growth has been one of the strongest in the G-20 and the region. Policy responses have been appropriate to manage the large external shocks and the slowing economy.

\footnotetext{
${ }^{12}$ The additional sources of potential financing include a three-year swap line with China for Y 100 billion ( $\$ 15$ billion), an approximately $\$ 12$ billion credit line from the Chiang Mai Initiative Multilateralized, and a $¥ 1 \frac{1}{2}$ trillion swap line with Japan; the terms and modalities of these financing lines are still being discussed.

${ }^{13}$ Previous staff analysis indicates that when the large increase in the size and volatility of capital flows to Indonesia - against which reserves provide insurance - is accounted for, it makes sense to judge the adequacy of foreign reserves against a broader measure of the country's external liabilities, not only short-term debt. Although reserves have doubled in dollar terms since 2000, they have not increased much compared to the rise in gross external liabilities (reserves accounted for 173/4 percent of gross external liabilities in 2000 and about $21 \frac{1}{2}$ percent in 2008). See M. Ruiz-Arranz and M. Zavadjil, "Adequacy of Indonesia's Foreign Exchange Reserves," IMF Country Report No. 08/298. Reserves as a percent of broad money have also declined from 38 percent in 2000 to 30 percent in 2008.
} 
29. Protecting economic and financial stability is the biggest challenge. With growth weakening and subject to the swings of the global environment, the government and BI need to continue to focus on achieving the appropriate policy mix to support growth in a volatile global environment, protect macroeconomic and financial sector stability, and alleviate potential stresses to the balance of payments, particularly if major global risk aversion or external liquidity risks return.

30. Implementation of the fiscal stimulus package for 2009 and maintaining some stimulus in 2010 are important for supporting growth. The final growth dividend from the 2009 fiscal stimulus depends on its execution, especially of the capital spending measures given their estimated higher multiplier effect. For 2010, a deficit close to 2 percent of GDP would be consistent with a countercyclical policy, provide room for greater spending on much needed infrastructure and social services, while also supporting further debt consolidation.

\section{Progress on structural fiscal reforms could enhance budget flexibility and} improve stabilization policy. Several measures are already underway, including strengthening cash management, simplifying budget execution procedures, and establishing a consolidated TSA. Additional reforms would improve fiscal management, including lowering energy subsidies, expanding the non-commodity tax base, strengthening tax administration, and improving subnational government reporting.

\section{The monetary easing cycle was timely and appropriate; going forward, a more} cautious stance is warranted. Although inflationary pressures remain low and credit growth was flat for the first five months of the year, there is ample stimulus in the pipeline and a cautionary stance is appropriate until the direction of the economy can be fully gauged. Monetary transmission is experiencing normal lags, and the interest rate reductions already implemented should soon be reflected in higher credit expansion and help support a recovery in investment, removing the need for any additional measures to support lending growth. The exchange rate is broadly in equilibrium and its flexibility has served well as an external shock absorber.

\section{Further strengthening the financial sector framework will enhance stability.}

Aided by supportive policy measures, the Indonesian banking sector proved resilient to the effects of the global financial turmoil. Close supervisory vigilance remains warranted as asset quality is expected to deteriorate in sectors that have been more affected by the global slowdown. At the same time, smaller and some mid-sized banks remain vulnerable to liquidity risk given their unstable funding base, including difficulties accessing markets in times of heightened market volatility. Quickly responding to any emerging problems would be important in safeguarding the sector's stability. Parliamentary approval of the Financial 
Safety Net law and further strengthening the supervisory framework would help maintain asset quality and enhance public confidence. The FSAP will provide useful inputs to guide further financial sector reform.

34. The current reserve position is adequate to handle moderate external shocks.

However, it leaves a relatively small buffer should global risk aversion deteriorate substantially. Given the prevailing uncertainties for private capital flows and the scope for a resurgence in global risk aversion, somewhat larger reserve buffers would help boost market confidence.

35. It is recommended that the next Article IV consultation take place on the standard 12-month cycle. 
Figure 1. Indonesia: Financial Market Performance

Reflecting improved sentiment, the stock market has recovered after the sharp decline in H2 2008.

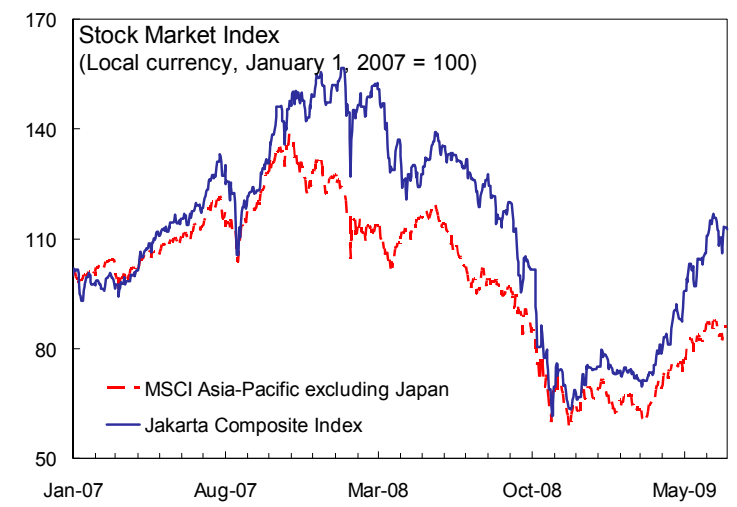

...government bond yields have returned to their pre-crisis level...

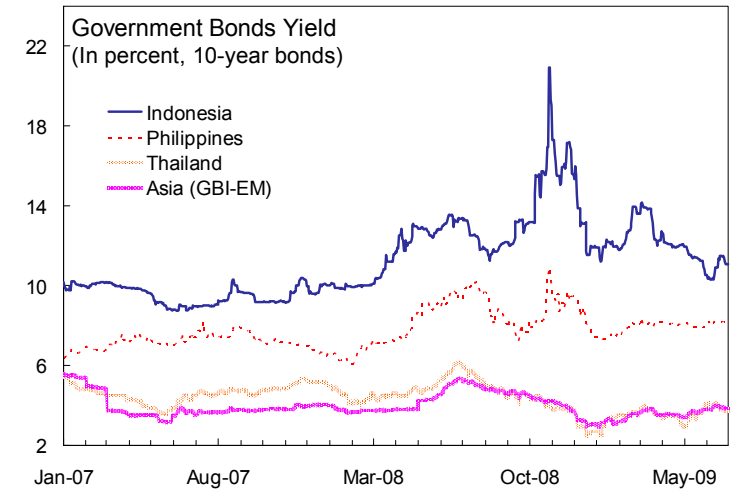

The rupiah exchange rate has been rebounding since March 2009...

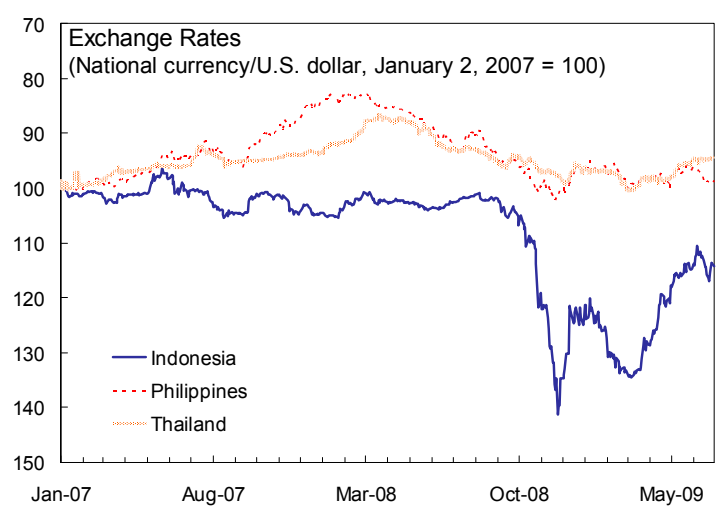

Sovereign external bond spreads are on a decline...

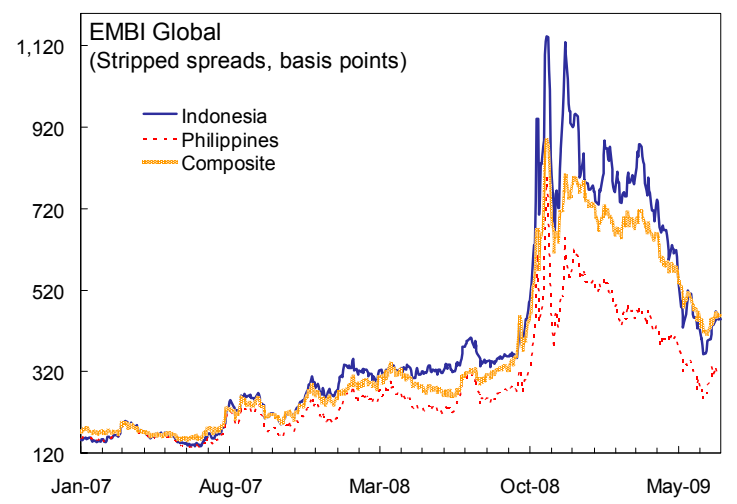

....and the yield curve is lower.

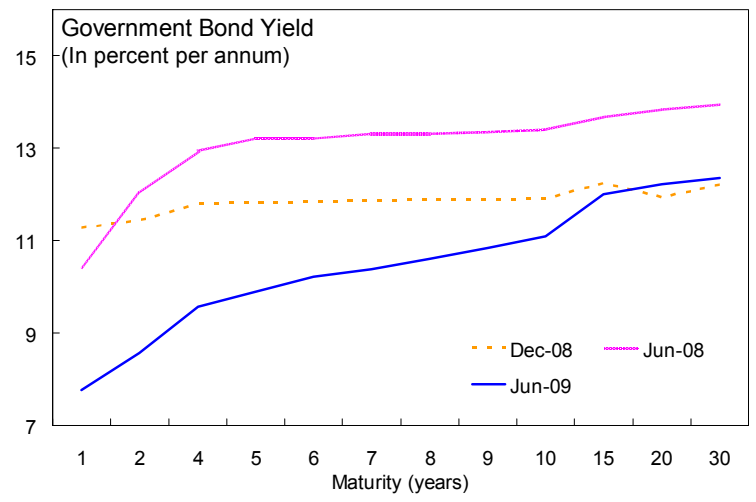

...and foreign exchange reserves are rising, reflecting renewed capital inflows.

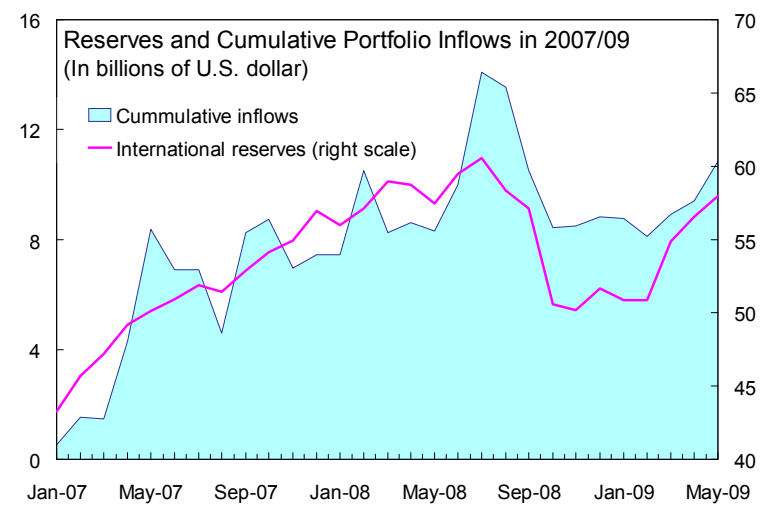

Source: CEIC Data Co., Ltd.; Bloomberg L.P.; country authorities; and Fund staff calculations. 
Figure 2. Indonesia: Macroeconomic Developments and Outlook

GDP growth is expected to slow in 2009 due to weaker domestic and external demand.

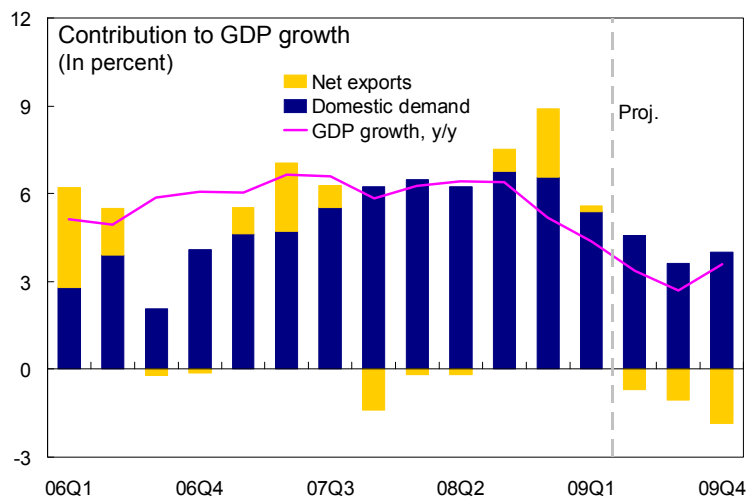

Leading indicators such as consumer confidence...

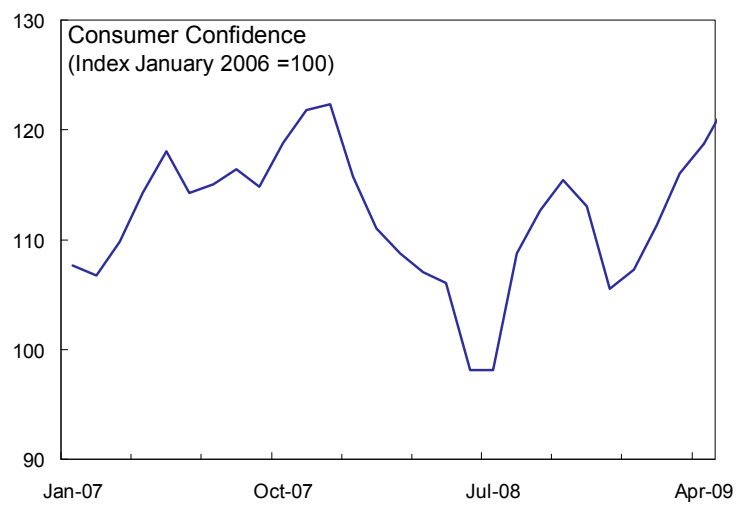

The collapse in exports has also bottomed out...

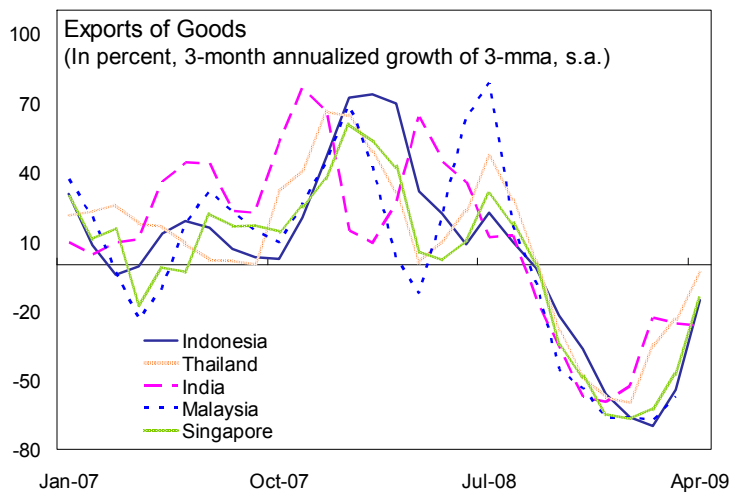

Credit growth has decelerated, particularly for working capital.

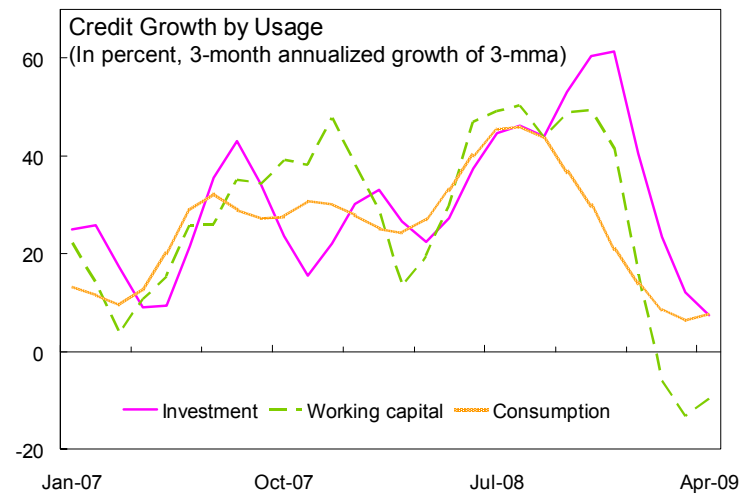

...and other indicators suggest that the economy may have bottomed out in Q1 2009.

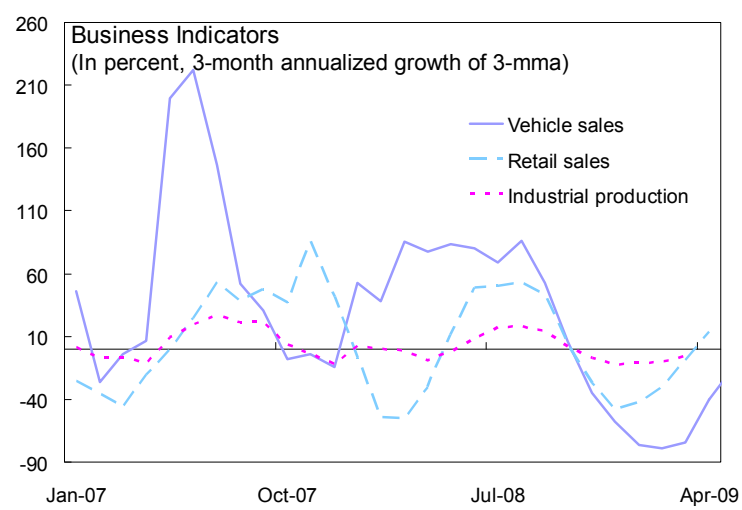
...and falling imports has resulted in a small current account surplus in Q1 2009.

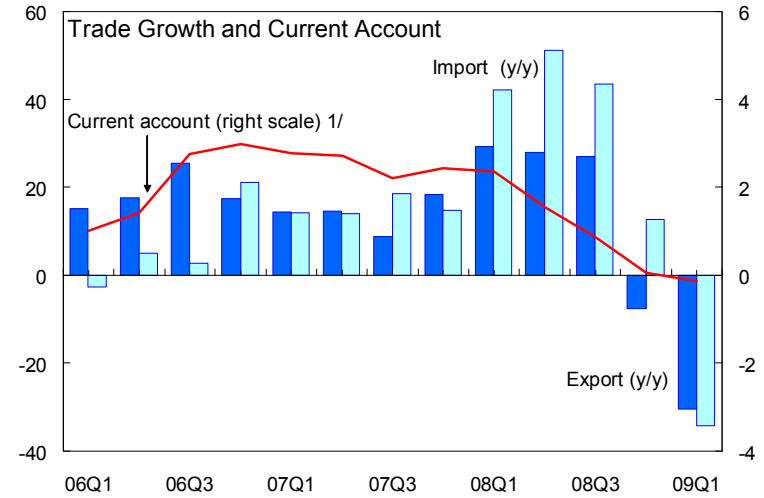

Source: CEIC Data Co., Ltd.; and Fund staff calculations and estimates.

$1 /$ In percent of GDP, fourth quarter moving average. 
Figure 3. Indonesia: Inflation and Monetary Developments

Inflation has been decelerating since October 2008 after rising sharply in $\mathrm{H} 12008 \ldots$

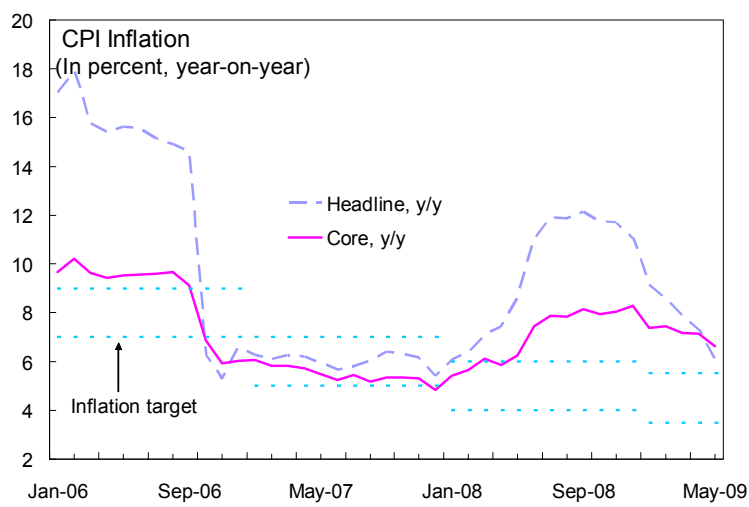

The acceleration in credit growth in previous years has receded...

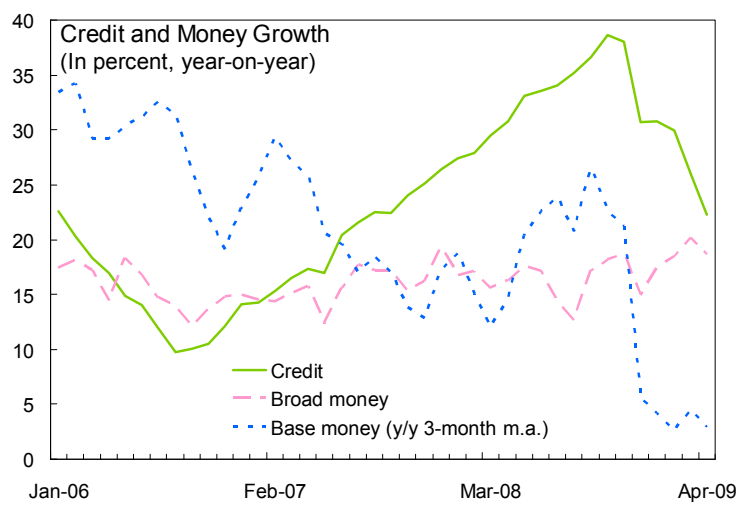

Real interest rates are broadly neutral...

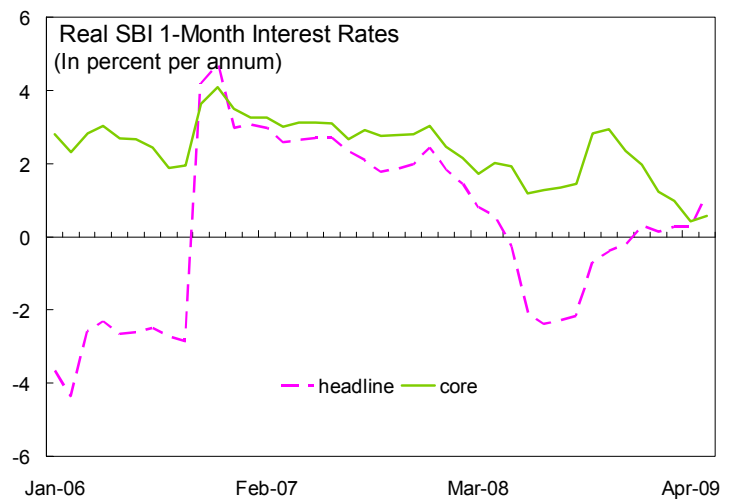

....as a result of food and fuel price fluctuations and domestic demand activity.

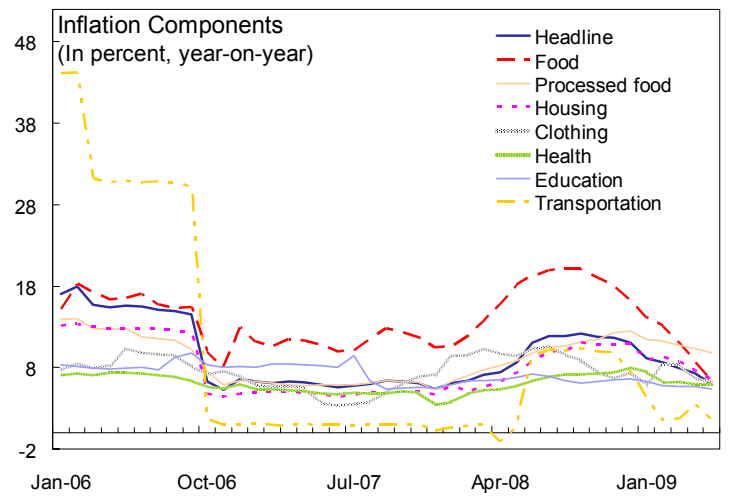

... and $\mathrm{BI}$ has lowered its policy rate in line with lower inflation and slower economic activity.

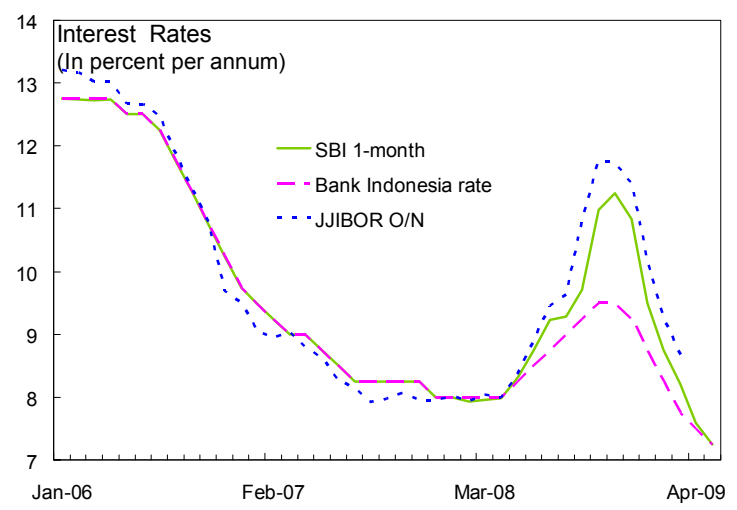

...and the transition of the rate cuts to deposit and lending rates is proceeding slowly.

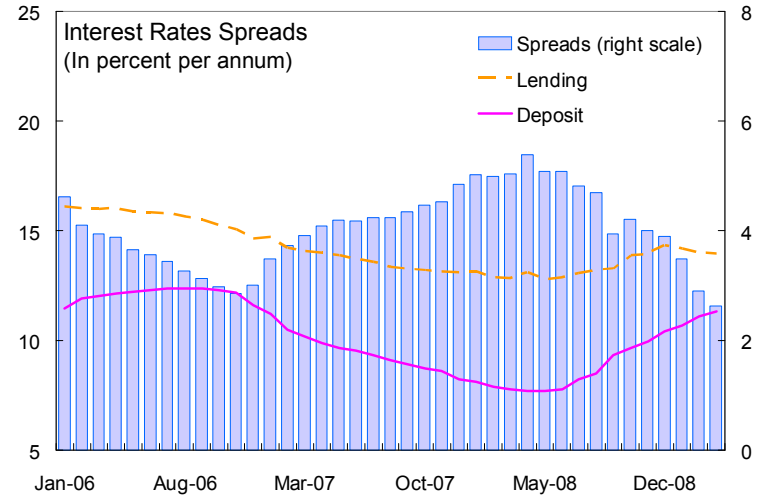

Source: CEIC Data Co., Ltd.; country authorities; and Fund staff calculations. 
Figure 4. Indonesia: Banking Sector Indicators

The banking sector has so far withstood the crisis well: profitability is among the highest in the region,...

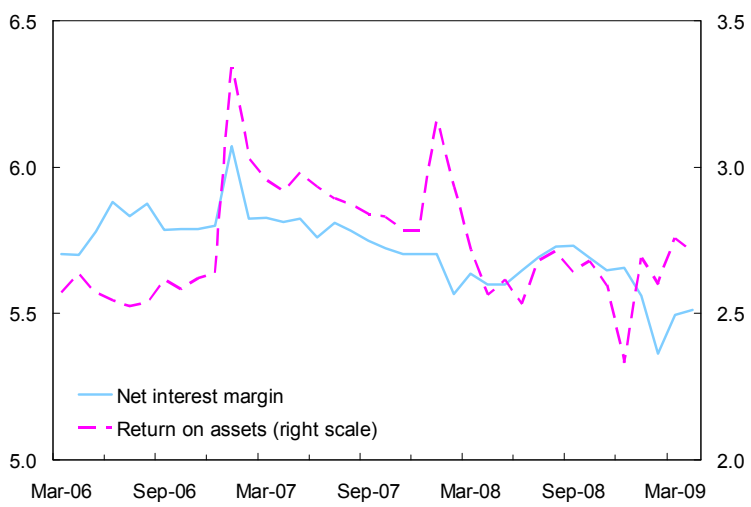

The average loan loss ratio of over 100 percent suggests adequate coverage

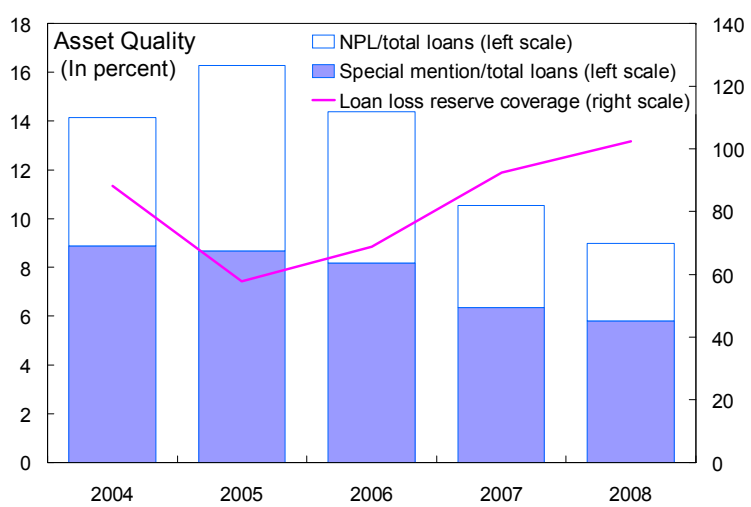

Banks have large capital cushions to withstand further shocks

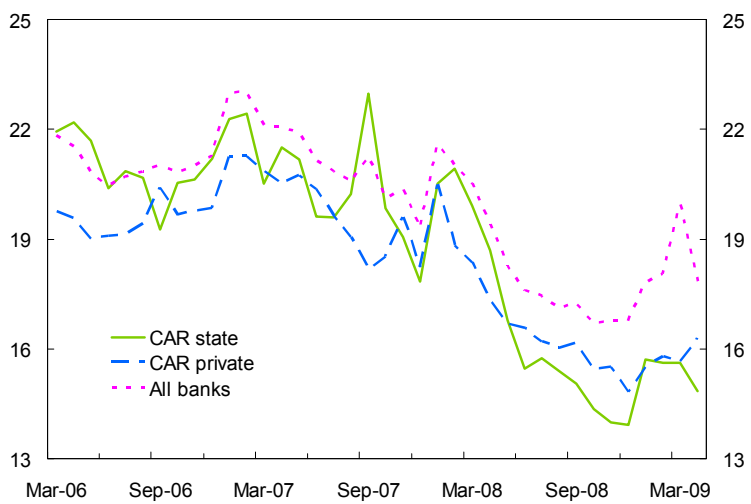

...asset quality remained steady in 2008, although NPLs have inched up in 2009.

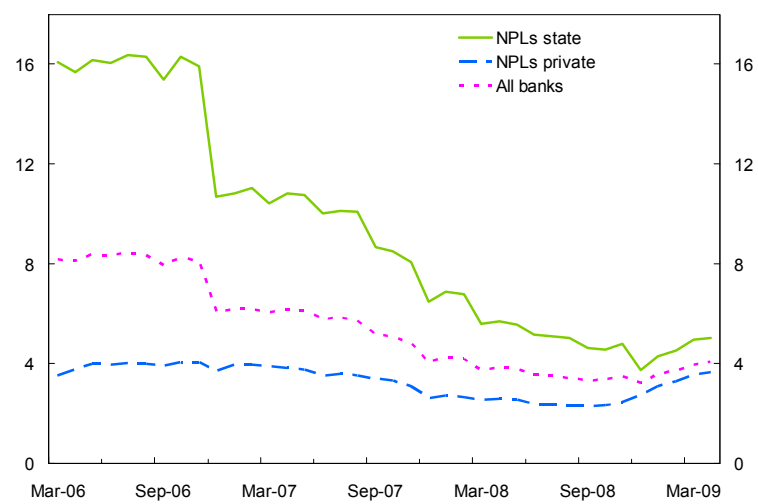

Liquidity remains ample and has recovered from the squeeze in late 2008, as evidenced by the high stock of $S B / s$

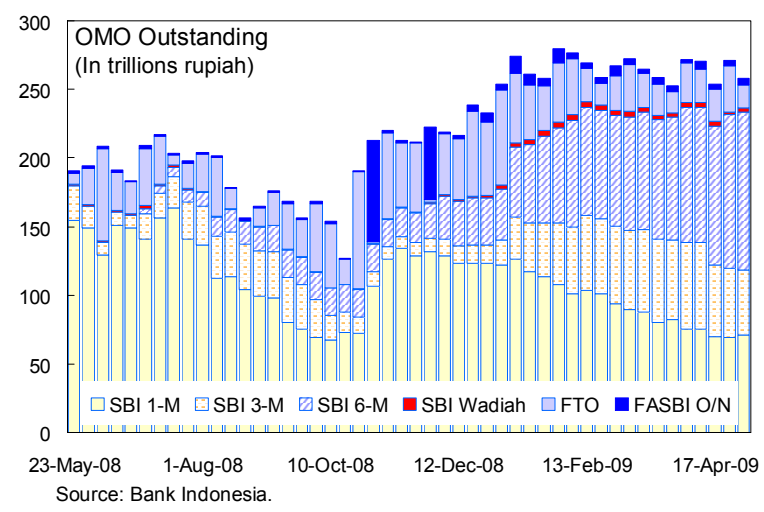

And default probabilities are falling in line with the recovery in the stock market.

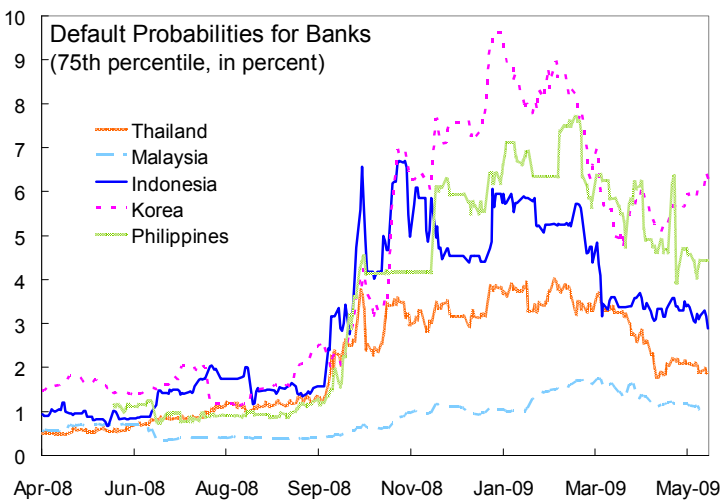

Source: CEIC Data Co., Ltd.; country authorities; and Fund staff calculations. 
Figure 5. Indonesia: Corporate Sector Indicators

SME's access to credit has been curtailed...

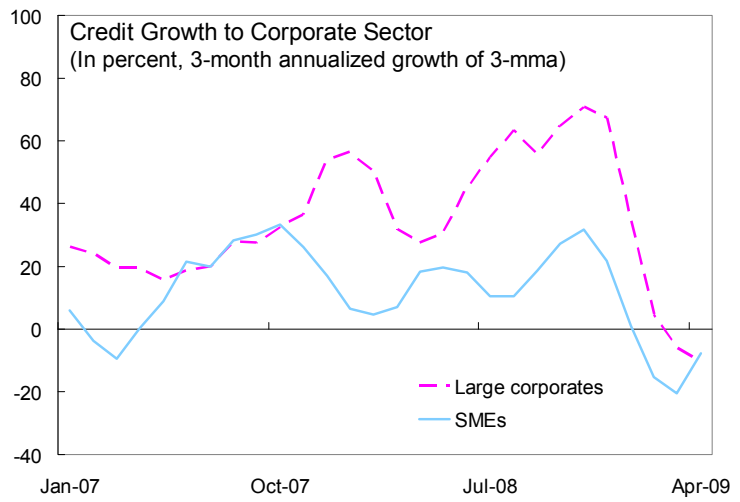

Issuance in the domestic corporate bond market has resumed after activity slowed in $\mathrm{H} 22008$.

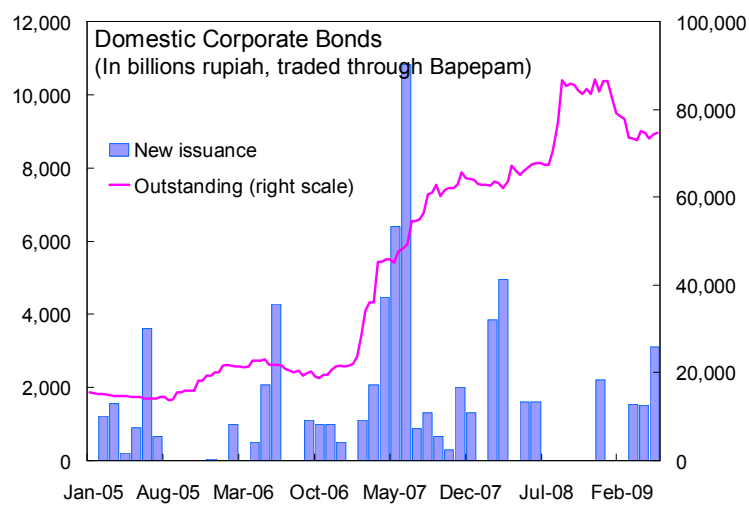

Despite recent volatility, the health of the corporate sector remains strong as evidenced by declining leverage, improving liquidity...

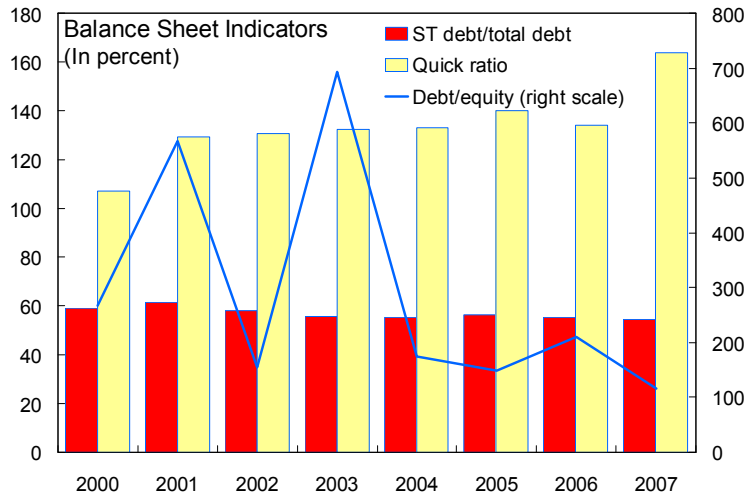

...more than for large corporates.

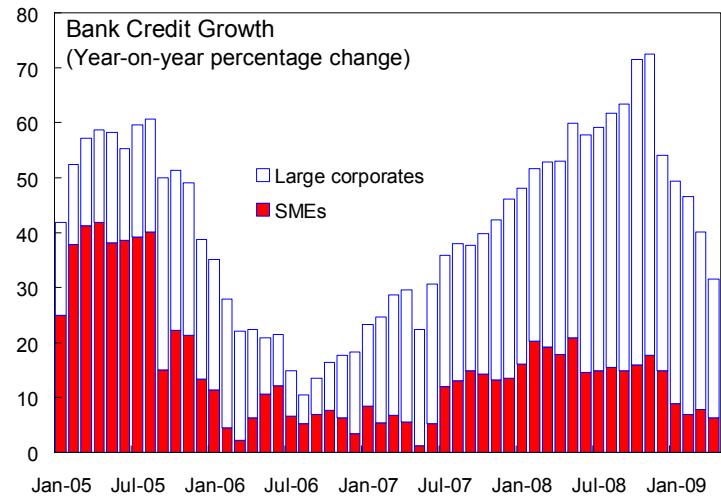

Default probabilities are starting to fall following the sharp increase in the last quarter of 2008.

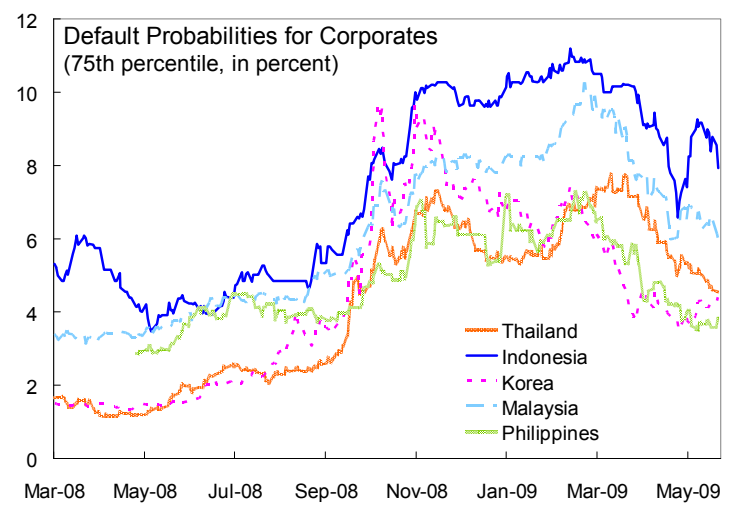

... and rising profitability over recent years

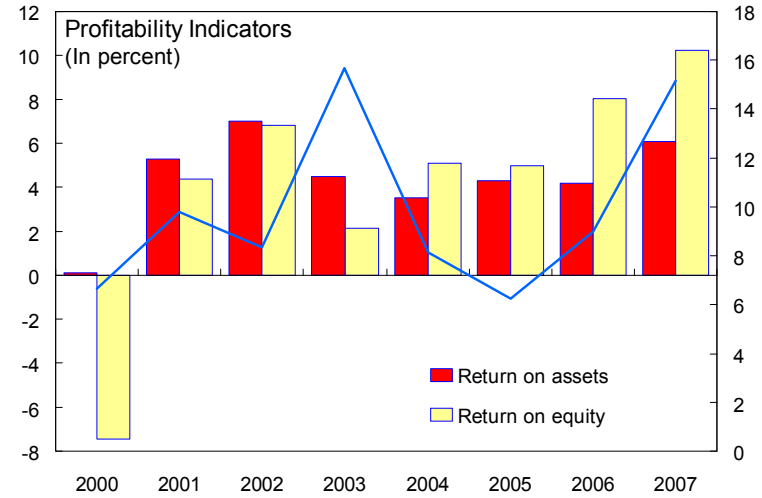

Source: CEIC Data Co., Ltd.; Bloomberg L.P.; and Moody KMV. 
Figure 5. Indonesia: Corporate Sector Indicators (Concluded)

After the deleveraging process following the Asian crisis, corporate debt ratios are now below the average in Emerging Asia.

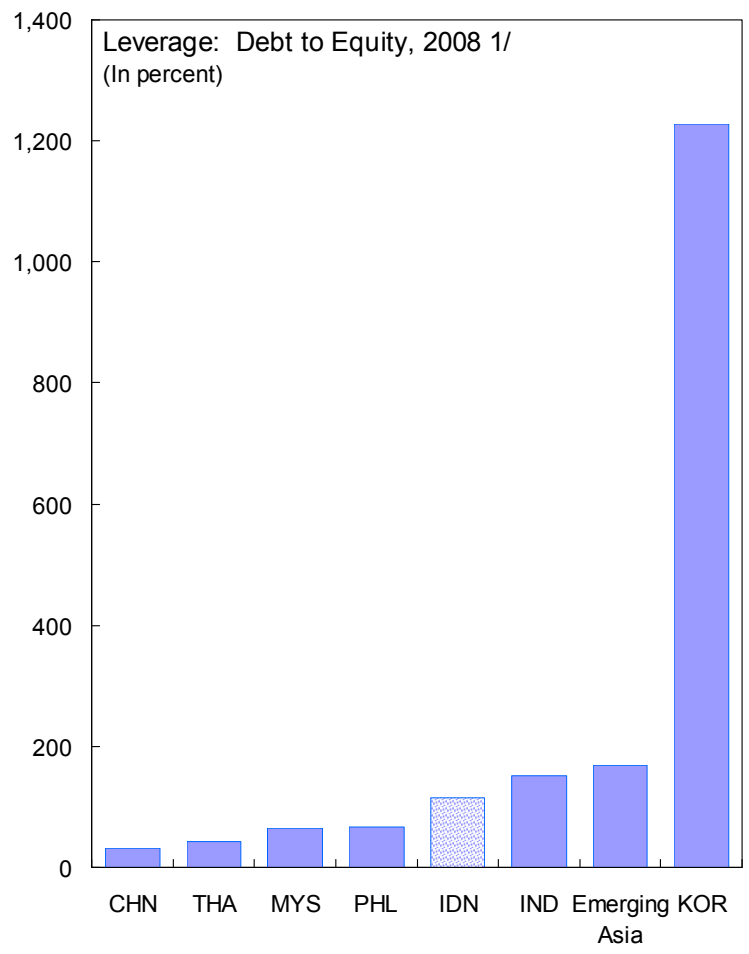

Liquidity ratios are healthy...

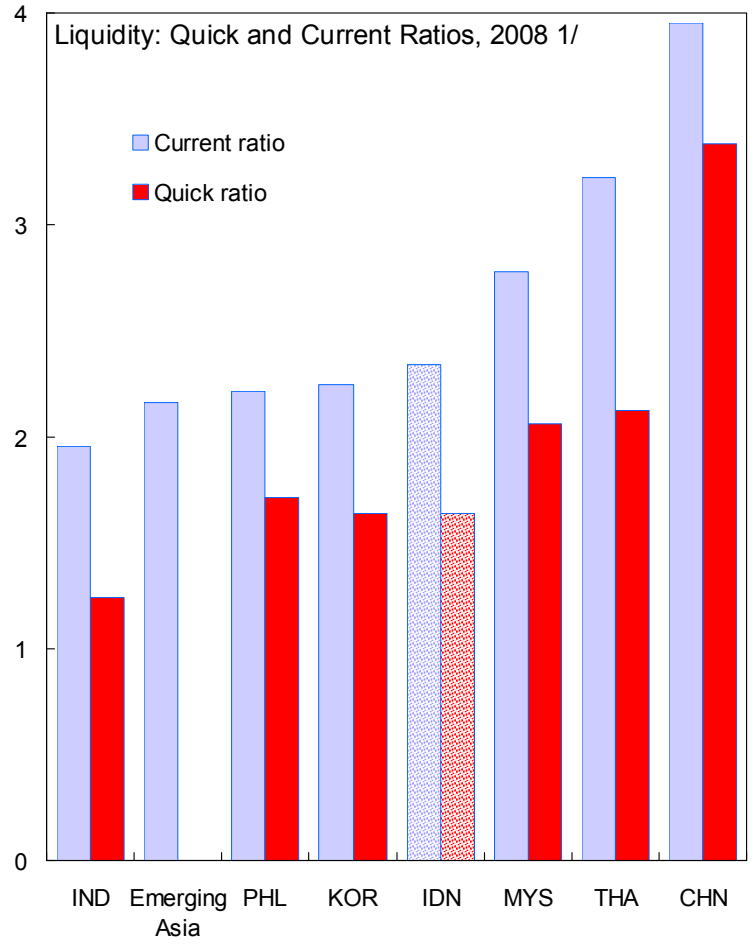

Source: IMF, Corporate Vulnerability Utility.

1/ 2007 data for Indonesia.
Profitability indicators have improved, but remain low relative to some regional peers.

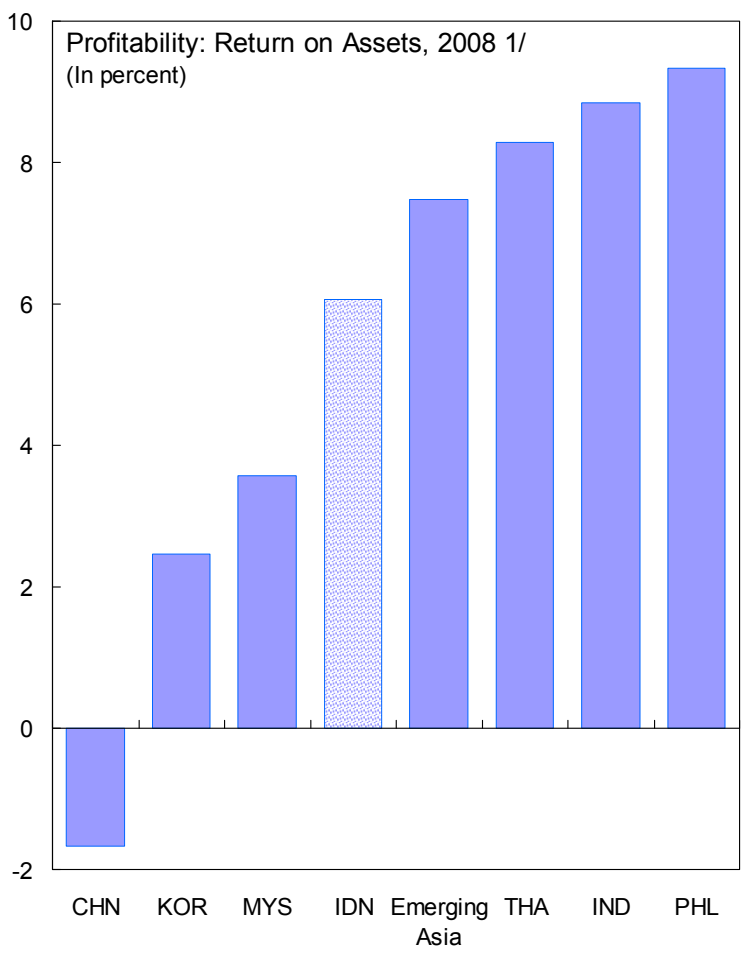

...and net foreign exposure remains low.

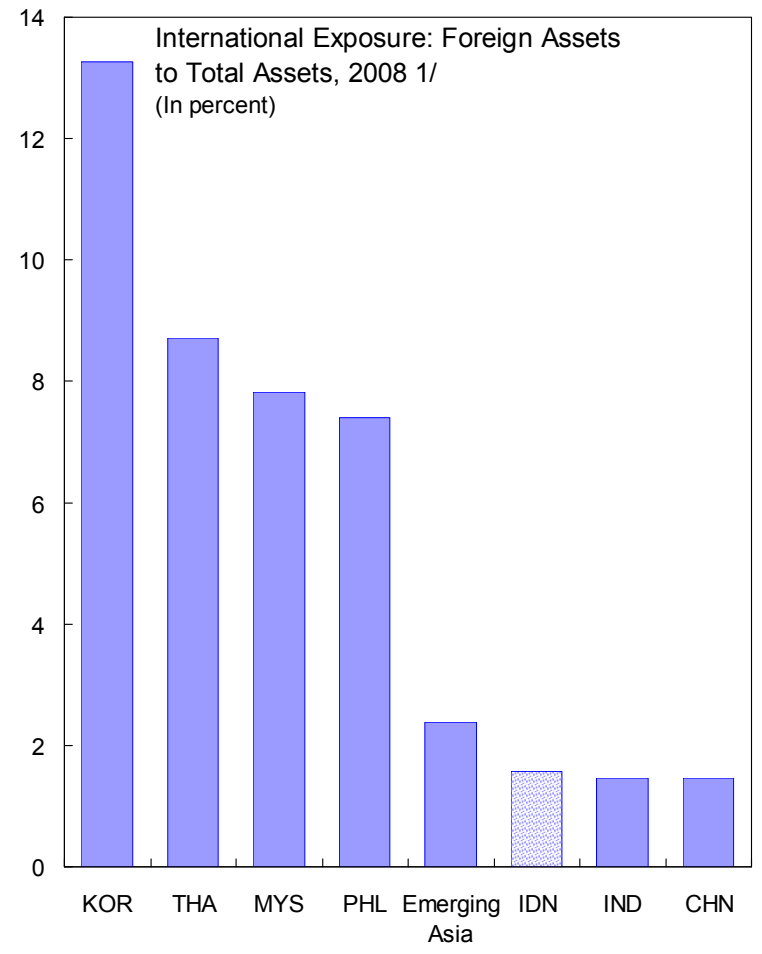


Figure 6. Indonesia: Recent Regional Developments

Although Q1 2009 outturns in Asia were below expectations, there are signs of improvement.

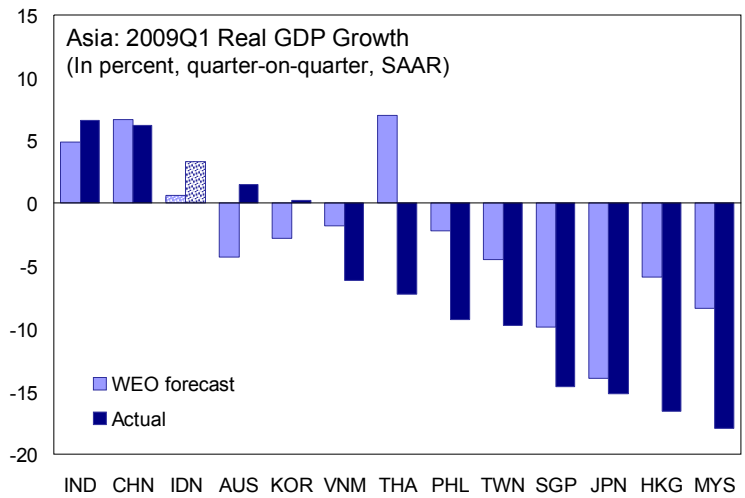

...exports are recovering from recent troughs...

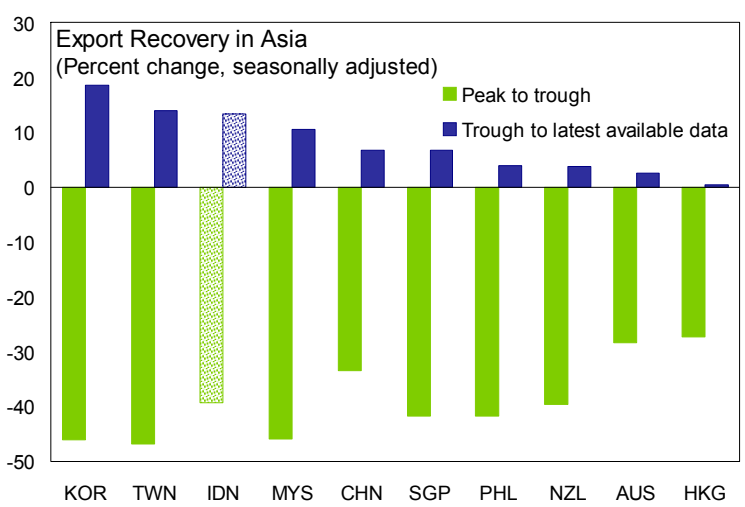

China's imports are a contributing factor to the recovery...

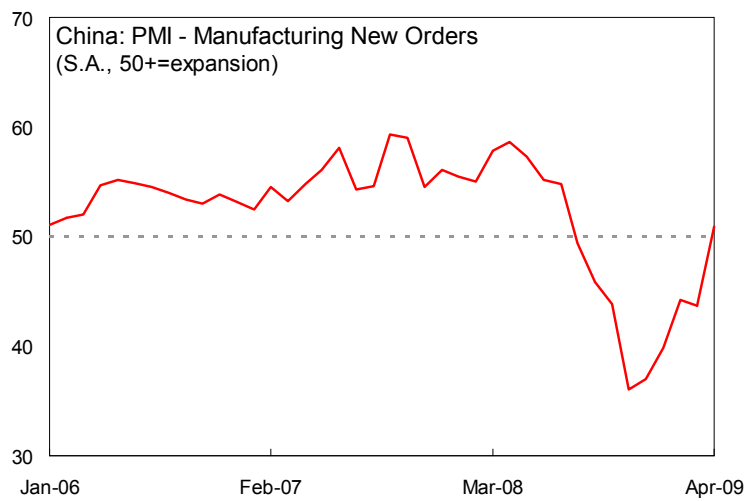

Financial pressures are easing...

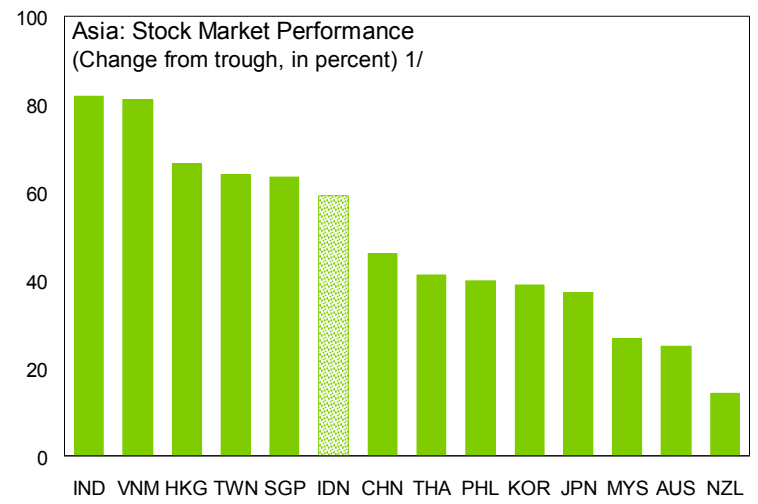

....as is industrial production.

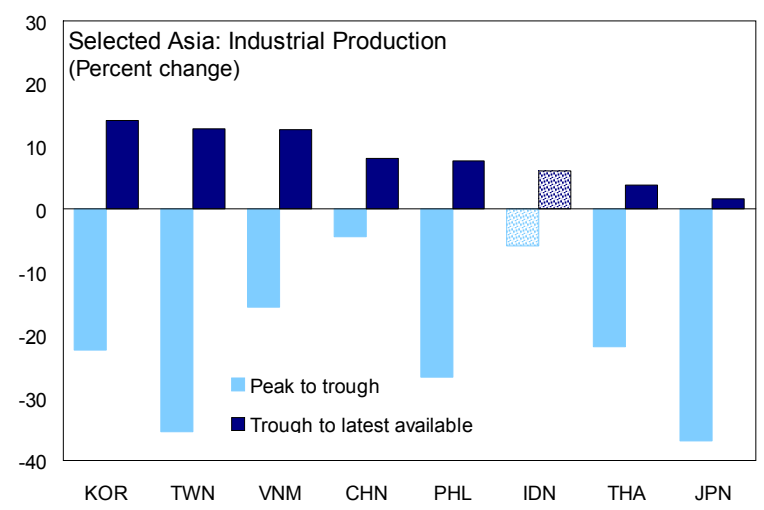
...although uncertainty in the U.S. and Euro zone still prevail.

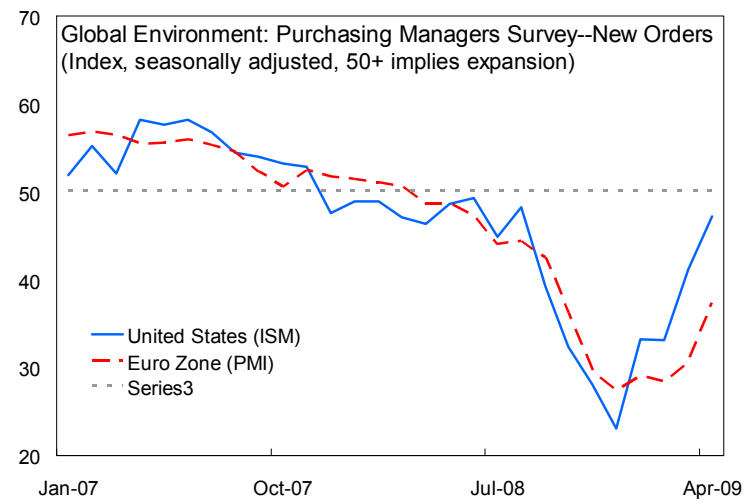

Source: IMF, World Economic Outlook; Haver Analytic; CEIC Data Co., Ltd.; and Fund staff calculations.

1/ Trough in the level of the stock market index in 2009 year-to-date. Except for China, Taiwan Province of China and Vietnam troughs occur in March 2009. 
Table 1. Indonesia: Summary of Financial Sector Interventions

(September 2008-April 2009)

\begin{tabular}{|c|c|c|c|c|}
\hline Benchmark Policy Rates & Liquidity Support & $\begin{array}{l}\text { Securities Market } \\
\text { Support }\end{array}$ & $\begin{array}{l}\text { Deposit Insurance/ } \\
\text { Debt Guarantees }\end{array}$ & $\begin{array}{l}\text { Bank Recap/Asset } \\
\text { Purchases/Other Fiscal } \\
\text { and Regulatory }\end{array}$ \\
\hline $\begin{array}{l}\text { Bl's overnight repo rate cut by } \\
200 \text { bps to } 10.25 \text { percent and } \\
\text { overnight deposit rate } \\
\text { increased by } 125 \text { bps to } \\
8.50 \text { percent } \\
\text { (September } 16,2008 \text { ) }\end{array}$ & $\begin{array}{l}\text { Reserve requirement for foreign } \\
\text { currency deposits cut from } \\
3 \text { percent to } 1 \text { percent } \\
\text { (October } 13,2008 \text { ) and for rupiah } \\
\text { deposits from } 9.1 \text { percent average } \\
\text { to } 7.5 \text { percent (October } 24,2008 \text { ) }\end{array}$ & $\begin{array}{l}\text { Ban of short-selling, stock } \\
\text { market shut down for three } \\
\text { days, and trading in Backrie } \\
\text { shares suspended } \\
\text { (October } 8-10,2008 \text { ). } \\
\text { Short-selling allowed again in } \\
\text { February } 2009 \text {. }\end{array}$ & $\begin{array}{l}\text { Deposit insurance coverage } \\
\text { extended from Rp } 100 \text { million to } \\
\text { Rp } 2 \text { billion for both local and } \\
\text { foreign currency deposits } \\
\text { (October } 13,2008 \text { ) }\end{array}$ & $\begin{array}{l}\text { Temporary suspension of } \\
\text { mark-to-market valuation } \\
\text { requirements on banks' bond } \\
\text { holdings (October } 9,2008 \text { ) }\end{array}$ \\
\hline $\begin{array}{l}\text { BI policy rate lowered by } \\
25 \text { bps to } 9.25 \text { percent and } \\
\text { interest corridor narrowed to } \\
100 \text { bps, from } 200 \text { bps } \\
\text { (December } 4,2008 \text { ). } \\
\text { BI policy rate lowered by } \\
50 \text { bps to } 8.75 \text { percent } \\
\text { (January } 7,2009 \text { ) }\end{array}$ & $\begin{array}{l}\text { Banks allowed to use SBls and } \\
\text { government bonds worth } \\
2.5 \text { percent of their total rupiah } \\
\text { deposits as secondary reserves } \\
\text { (October } 22,2008 \text { ) }\end{array}$ & $\begin{array}{l}\text { New regulations for share } \\
\text { buy-backs issued (daily limits } \\
\text { scrapped and rule requiring } \\
\text { shareholder approval } \\
\text { removed); state firms to } \\
\text { conduct share buy-backs } \\
\text { (October } 9,2009 \text { ) }\end{array}$ & $\begin{array}{l}\text { Issuance of decree-in-lieu-of- } \\
\text { law establishing a Financial } \\
\text { Safety Net (October 15, 2008) } \\
\text { Legislation is still under } \\
\text { discussion by parliament. }\end{array}$ & $\begin{array}{l}\text { All bond auctions suspended } \\
\text { until end-2008; government } \\
\text { and BI initiate buy-back } \\
\text { program of government bonds } \\
\text { (October 2008) }\end{array}$ \\
\hline $\begin{array}{l}\text { BI policy rate lowered by } \\
50 \text { bps to } 8.25 \text { percent } \\
\text { (February } 4,2009 \text { ) }\end{array}$ & $\begin{array}{l}\text { Rupiah liquidity injected through } \\
\text { repos, expansion of eligible } \\
\text { collateral for short-term financing } \\
\text { with } \mathrm{BI}, \mathrm{FX} \text { swap facilities } \\
\text { expanded } \\
\text { (October } 13,2008 \text { ) }\end{array}$ & & $\begin{array}{l}\text { Banks allowed to sell export } \\
\text { receivables to the central bank } \\
\text { (December } 8,2008) \text {. A new } \\
\text { export financing agency created } \\
\text { to provide trade guarantees, } \\
\text { insurance, and lending } \\
\text { (December } 17,2008) \text {. }\end{array}$ & $\begin{array}{l}\text { Monitoring of foreign exchange } \\
\text { transactions strengthened by } \\
\text { requiring documentation for } \\
\text { underlying transactions in } \\
\text { excess of } \$ 100,000 \\
\text { (November } 13,2008)\end{array}$ \\
\hline $\begin{array}{l}\text { BI policy rate lowered by } \\
50 \text { bps to } 7.75 \text { percent } \\
\text { (March } 4,2009 \text { ) }\end{array}$ & $\begin{array}{l}\text { State firms required to repatriate } \\
\text { export proceeds and transfer their } \\
\text { foreign currency deposits to } \\
\text { domestic banks } \\
\text { (October } 28,2008)\end{array}$ & & $\begin{array}{l}\text { Deposit Insurance Corporation } \\
\text { took over Bank Century } \\
\text { (November } 21,2008 \text { ) }\end{array}$ & $\begin{array}{l}\text { New regulation banning } \\
\text { structured currency derivatives } \\
\text { products (November } 27 \text { and } \\
\text { December } 17,2008)\end{array}$ \\
\hline $\begin{array}{l}\text { BI policy rate lowered by } \\
25 \text { bps to } 7.50 \text { percent } \\
\text { (April 3) }\end{array}$ & $\begin{array}{l}\text { Commodities exporters required to } \\
\text { use letters of credit issued by local } \\
\text { banks in future, to make sure that } \\
\text { foreign exchange remains onshore } \\
\text { (announced January } 9,2009 ; \\
\text { implementation delayed till April 1) }\end{array}$ & & $\begin{array}{l}\text { BI revoked the business license } \\
\text { of Bank IFI. Deposit Insurance } \\
\text { Corporation to handle } \\
\text { liquidation process (April 17, } \\
\text { 2009) }\end{array}$ & $\begin{array}{l}\text { BI announced Basel II adoption } \\
\text { postponed and new regulation } \\
\text { to ease capital requirements on } \\
\text { SME loans (February } 2,2009 \text { ) }\end{array}$ \\
\hline
\end{tabular}


Table 2. Indonesia: Selected Economic Indicators, 2006-10

Nominal GDP (2008): Rp 4,954 trillion or US $\$ 512$ billion

Main exports (percent of total, 2008): mineral fuels (29), manufactured goods (15), machinery and transport equipment (13)

GDP per capita (2008): US $\$ 2,297$

Unemployment rate (2008): 8.4

FDI (2008, net): US $\$ 2.0$ billion

Public debt (2008, gross): 32.3 percent of GDP

Foreign public debt (2008): 11.9 percent of GDP

Poverty headcount ratio at national poverty line (2008): 15.4 percent of population

\begin{tabular}{|c|c|c|c|c|c|}
\hline & 2006 & 2007 & 2008 & 2009 & 2010 \\
\hline & \multicolumn{3}{|c|}{ Actual } & \multicolumn{2}{|c|}{ Projection } \\
\hline Real GDP (percent change) & 5.5 & 6.3 & 6.1 & 3.5 & 4.5 \\
\hline Domestic demand & 3.2 & 4.1 & 7.7 & 4.9 & 5.5 \\
\hline \multicolumn{6}{|l|}{ Of which: } \\
\hline Private consumption & 3.2 & 5.0 & 5.3 & 4.9 & 5.1 \\
\hline Gross fixed investment & 2.6 & 9.4 & 11.7 & 3.2 & 7.6 \\
\hline Change in stocks $1 /$ & -0.3 & -1.6 & 0.2 & 0.0 & 0.0 \\
\hline Net exports $1 /$ & 1.1 & 0.6 & 0.7 & -0.9 & -0.5 \\
\hline Statistical discrepancy $1 /$ & 1.4 & 1.9 & -1.4 & 0.0 & 0.0 \\
\hline \multicolumn{6}{|l|}{ Saving and investment (in percent of GDP) } \\
\hline Gross investment 2/ & 24.1 & 25.0 & 27.6 & 26.9 & 27.7 \\
\hline Gross national saving & 27.1 & 27.4 & 27.7 & 27.2 & 27.2 \\
\hline Foreign saving (external current account balance) & -3.0 & -2.4 & -0.1 & -0.3 & 0.4 \\
\hline \multicolumn{6}{|l|}{ Prices (12-month percent change) } \\
\hline Consumer prices (end period) & 6.6 & 5.6 & 11.1 & 5.0 & 5.5 \\
\hline Consumer prices (period average) & 13.1 & 6.2 & 9.8 & 5.6 & 6.3 \\
\hline \multicolumn{6}{|l|}{ Public finances (in percent of GDP) } \\
\hline Central government revenue & 18.8 & 17.9 & 19.1 & 15.8 & 15.8 \\
\hline Central government expenditure & 19.7 & 19.1 & 19.2 & 18.4 & 17.8 \\
\hline Central government balance & -1.0 & -1.2 & -0.2 & -2.6 & -2.0 \\
\hline Primary balance & 1.4 & 0.8 & 1.6 & -0.6 & -0.1 \\
\hline Central government debt & 39.0 & 35.1 & 33.2 & 31.1 & 31.0 \\
\hline \multicolumn{6}{|l|}{ Money and credit (12-month percent change; end of period) } \\
\hline Rupiah M2 & 18.0 & 19.5 & 12.6 & $\ldots$ & $\ldots$ \\
\hline Base money & 28.3 & 26.5 & -2.9 & $\ldots$ & $\ldots$ \\
\hline Private sector credit & 12.1 & 22.4 & 30.7 & $\ldots$ & $\ldots$ \\
\hline One-month SBI rate (period average) & 11.8 & 8.6 & 9.1 & $\ldots$ & $\ldots$ \\
\hline \multicolumn{6}{|l|}{ Balance of Payments (in billions of U.S. dollars) } \\
\hline Oil and gas (net) & 6.8 & 5.7 & 7.8 & 7.4 & 6.7 \\
\hline Non-oil exports (f.o.b) & 80.6 & 93.1 & 107.9 & 80.0 & 81.7 \\
\hline Non-oil imports (f.o.b) & -57.7 & -66.1 & -92.8 & -66.1 & -69.9 \\
\hline Current account balance & 10.9 & 10.5 & 0.3 & 1.4 & -2.4 \\
\hline Foreign direct investment & 2.2 & 2.3 & 2.0 & 3.0 & 2.6 \\
\hline Overall balance & 14.2 & 12.7 & -5.3 & 10.4 & 3.0 \\
\hline \multicolumn{6}{|l|}{ Gross reserves } \\
\hline In billions of U.S. dollars (end period) & 42.6 & 56.9 & 51.6 & 62.1 & 65.1 \\
\hline In months of imports & 4.7 & 4.7 & 6.0 & 6.8 & 6.5 \\
\hline As a percent of short-term debt $3 /$ & 153.6 & 179.9 & 140.2 & 197.6 & 194.8 \\
\hline \multicolumn{6}{|l|}{ Total external debt } \\
\hline In billions of U.S. dollars & 129.5 & 137.4 & 149.7 & 153.0 & 157.5 \\
\hline In percent of GDP & 35.5 & 31.8 & 29.3 & 29.4 & 27.5 \\
\hline \multicolumn{6}{|l|}{ Net international investment position } \\
\hline In billions of U.S. dollars & -146 & -151 & $\ldots$ & $\ldots$ & $\ldots$ \\
\hline In percent of GDP & -40 & -35 & $\ldots$ & $\ldots$ & $\ldots$ \\
\hline \multicolumn{6}{|l|}{ Exchange rate (period average) } \\
\hline Rupiah per U.S. dollar & 9,165 & 9,141 & 9,439 & $\ldots$ & $\ldots$ \\
\hline Nominal effective exchange rate (Jan. $2000=100$ ) & 83.7 & 80.9 & 73.6 & $\ldots$ & $\ldots$ \\
\hline \multicolumn{6}{|l|}{ Memorandum items: } \\
\hline Oil production $(000 \mathrm{bcpd})$ & 956 & 899 & 927 & 960 & 965 \\
\hline Indonesian oil price (US\$/bbl) & 63.9 & 70.7 & 96.6 & 60.1 & 74.1 \\
\hline Nominal GDP (in trillions of rupiah) & 3,339 & 3,957 & 4,954 & 5,413 & 6,015 \\
\hline Nominal GDP (in billions of U.S. dollars) & 364 & 433 & 512 & 520 & 572 \\
\hline
\end{tabular}

Sources: Data provided by the Indonesian authorities; and Fund staff estimates.

1/ Contribution to GDP growth (percentage points).

$2 /$ Includes changes in stocks.

3 / Short-term debt on a remaining maturity basis. 
Table 3. Indonesia: Balance of Payments, 2006-10

(In billions of U.S. dollars)

\begin{tabular}{|c|c|c|c|c|c|}
\hline & $\begin{array}{r}2006 \\
\text { Act. }\end{array}$ & $\begin{array}{r}2007 \\
\text { Act. }\end{array}$ & $\begin{array}{r}2008 \\
\text { Act. }\end{array}$ & $\begin{array}{c}2009 \\
\text { Proj. }\end{array}$ & $\begin{array}{r}2010 \\
\text { Proj. }\end{array}$ \\
\hline Current account & 10.9 & 10.5 & 0.3 & 1.4 & -2.4 \\
\hline Goods, net (trade balance) & 29.7 & 32.8 & 22.9 & 21.3 & 18.5 \\
\hline Exports, f.o.b. & 103.5 & 118.0 & 139.6 & 99.1 & 103.6 \\
\hline Of which: Oil and gas & 23.0 & 24.9 & 31.7 & 19.1 & 21.9 \\
\hline Non-oil and gas & 80.6 & 93.1 & 107.9 & 80.0 & 81.7 \\
\hline Imports, f.o.b. & -73.9 & -85.3 & -116.7 & -77.8 & -85.2 \\
\hline Of which: Oil and gas & -16.2 & -19.2 & -23.9 & -11.7 & -15.3 \\
\hline Non-oil and gas & -57.7 & -66.1 & -92.8 & -66.1 & -69.9 \\
\hline Services, net & -9.9 & -11.8 & -12.7 & -10.8 & -11.2 \\
\hline Income, net & -13.8 & -15.5 & -15.3 & -13.8 & -14.4 \\
\hline Current transfers, net & 4.9 & 5.1 & 5.4 & 4.6 & 4.7 \\
\hline Capital and financial account & 2.8 & 3.6 & -5.5 & 9.0 & 5.4 \\
\hline Capital account & 0.4 & 0.5 & 0.3 & 0.1 & 0.1 \\
\hline Financial account & 2.4 & 3.0 & -5.8 & 8.9 & 5.3 \\
\hline Direct investment, net & 2.2 & 2.3 & 2.0 & 3.0 & 2.6 \\
\hline Abroad, net & -2.7 & -4.7 & -5.9 & -3.0 & -3.0 \\
\hline In Indonesia (FDI), net & 4.9 & 6.9 & 7.9 & 6.0 & 5.6 \\
\hline Portfolio investment, net & 4.3 & 5.6 & 1.7 & 7.4 & 6.2 \\
\hline Assets, net & -1.8 & -4.4 & -1.3 & -1.0 & -0.9 \\
\hline Liabilities & 6.1 & 10.0 & 3.0 & 8.4 & 7.2 \\
\hline Equity securities & 1.9 & 3.6 & 0.3 & 1.1 & 1.3 \\
\hline Debt securities & 4.2 & 6.4 & 2.7 & 7.3 & 5.9 \\
\hline Other investment & -4.1 & -4.8 & -9.5 & -1.5 & -3.4 \\
\hline Nonfinancial public sector & -2.8 & -2.4 & -1.4 & -1.4 & -1.4 \\
\hline Disbursements & 3.3 & 4.0 & 4.9 & 5.2 & 4.3 \\
\hline Repayments & -6.1 & -6.4 & -6.4 & -6.6 & -5.7 \\
\hline Banking sector & 0.4 & 0.1 & 1.4 & 0.4 & 1.1 \\
\hline Corporate sector & -0.8 & 1.1 & 2.8 & -0.2 & -0.4 \\
\hline Other $1 /$ & -0.9 & -3.6 & -12.3 & -0.2 & -2.8 \\
\hline Total & 13.6 & 14.1 & -5.2 & 10.4 & 3.0 \\
\hline Errors and omissions & 0.6 & -1.4 & -0.1 & 0.0 & 0.0 \\
\hline Overall balance & 14.2 & 12.7 & -5.3 & 10.4 & 3.0 \\
\hline Reserves and related items & -14.5 & -12.7 & 5.3 & -10.4 & -3.0 \\
\hline Changes in reserve assets & -6.9 & -12.7 & 5.3 & -10.4 & -3.0 \\
\hline \multicolumn{6}{|l|}{ Memorandum items: } \\
\hline Reserve assets position (eop) $2 /$ & 42.6 & 56.9 & 51.6 & 62.1 & 65.1 \\
\hline in months of imports of goods and services & 4.7 & 4.7 & 6.0 & 6.8 & 6.5 \\
\hline in percent of short-term debt at remaining maturity & 154 & 180 & 140 & 198 & 195 \\
\hline Current account (percent of GDP) & 3.0 & 2.4 & 0.1 & 0.3 & -0.4 \\
\hline Non-oil and gas exports, volume growth & 5.2 & -0.3 & 2.0 & -6.8 & 5.3 \\
\hline Non-oil and gas imports, volume growth & 5.5 & 6.3 & 33.0 & -6.2 & 6.0 \\
\hline Terms of trade, percent change (excluding oil) & 9.8 & 5.0 & 2.9 & -10.6 & 2.3 \\
\hline Terms of trade, percent change (including oil) & 6.2 & 3.2 & 2.0 & -4.6 & -1.6 \\
\hline Stock of nonfinancial public sector external debt & 71.4 & 73.5 & 81.4 & 86.1 & 89.0 \\
\hline in percent of GDP & 19.6 & 17.0 & 15.9 & 16.5 & 15.6 \\
\hline Nonfinancial public sector debt service (percent of exports) & 12.1 & 6.6 & 6.4 & 9.2 & 8.3 \\
\hline Indonesian oil price & 63.9 & 70.7 & 96.6 & 60.1 & 74.1 \\
\hline U.S. dollar GDP & 364.4 & 432.1 & 511.8 & 520.2 & 571.9 \\
\hline
\end{tabular}

Sources: Data provided by Bank Indonesia; and Fund staff estimates.

$1 /$ Includes unrecorded capital flows and exceptional financing.

2/ For 2009, it includes about $\$ 2.7$ billion that is expected to arise from the general and special SDR allocations. 
Table 4. Indonesia: Monetary Survey, 2005-09

(In trillions of rupiah, unless otherwise indicated, end of period)

\begin{tabular}{|c|c|c|c|c|c|}
\hline & $\begin{array}{r}2005 \\
\text { Dec }\end{array}$ & $\begin{array}{r}2006 \\
\text { Dec }\end{array}$ & $\begin{array}{r}2007 \\
\text { Dec }\end{array}$ & $\begin{array}{r}2008 \\
\text { Dec }\end{array}$ & $\begin{array}{r}2009 \\
\text { Apr }\end{array}$ \\
\hline \multicolumn{6}{|l|}{ Bank Indonesia } \\
\hline Net foreign assets & 255.7 & 380.9 & 534.1 & 561.8 & 603.0 \\
\hline Net domestic assets & 14.2 & -34.4 & -95.6 & -136.0 & -230.5 \\
\hline Net claims on government & 249.5 & 274.2 & 264.5 & 191.2 & 129.9 \\
\hline Net claims on financial corporations & -74.4 & -165.4 & -192.4 & -151.2 & -218.8 \\
\hline Others & -160.8 & -143.2 & -167.8 & -176.0 & -141.7 \\
\hline Base money & 270.0 & 346.5 & 438.5 & 425.8 & 372.5 \\
\hline \multicolumn{6}{|l|}{ Monetary survey } \\
\hline Net foreign assets & 307.4 & 405.2 & 513.9 & 596.8 & 666.3 \\
\hline Net domestic assets & 895.4 & 977.3 & $1,135.7$ & $1,299.0$ & $1,246.3$ \\
\hline Net claims on nonfinancial public sector & 520.8 & 539.6 & 558.4 & 450.3 & 417.1 \\
\hline Claims on private sector & 733.2 & 821.6 & $1,005.7$ & $1,314.0$ & $1,292.3$ \\
\hline Others & -358.6 & -383.9 & -428.4 & -465.3 & -463.2 \\
\hline Broad money & $1,202.8$ & $1,382.5$ & $1,649.7$ & $1,895.8$ & $1,912.6$ \\
\hline Rupiah, M2 & $1,016.8$ & $1,199.8$ & $1,433.9$ & $1,614.9$ & $1,629.5$ \\
\hline Currency in circulation & 124.0 & 150.7 & 183.0 & 209.7 & 189.9 \\
\hline Deposits & 892.9 & $1,049.2$ & $1,250.9$ & $1,405.1$ & $1,439.6$ \\
\hline Foreign exchage & 185.9 & 182.7 & 215.8 & 281.0 & 283.1 \\
\hline \multicolumn{6}{|l|}{ Memorandum items: } \\
\hline NIR of BI (US\$ billions) & 26.8 & 42.3 & 56.5 & 51.1 & 52.0 \\
\hline Money multiplier (rupiah M2) & 3.8 & 3.5 & 3.3 & 3.8 & 4.4 \\
\hline Base money velocity $1 /$ & 11.2 & 10.1 & 9.4 & 12.0 & 14.5 \\
\hline Rupiah broad money velocity $1 /$ & 2.5 & 2.5 & 2.5 & 2.7 & 2.8 \\
\hline \multicolumn{6}{|l|}{ Annual percentage change: } \\
\hline Broad money & 16.3 & 14.9 & 19.3 & 14.9 & 18.7 \\
\hline Rupiah broad money & 13.1 & 18.0 & 19.5 & 12.6 & 17.5 \\
\hline Base money & 30.9 & 28.3 & 26.5 & -2.9 & 3.2 \\
\hline Private sector claims & 21.0 & 12.1 & 22.4 & 30.7 & 19.6 \\
\hline
\end{tabular}

Sources: IMF, International Financial Statistics; and IMF staff estimates.

1/ Calculated using end-period quarterly GDP, annualized. 
Table 5. Indonesia: Summary of Central Government Operations, 2005-10

\begin{tabular}{|c|c|c|c|c|c|c|c|c|c|}
\hline & \multirow[b]{2}{*}{$\begin{array}{r}2005 \\
\text { Act. }\end{array}$} & \multirow[b]{2}{*}{$\begin{array}{r}2006 \\
\text { Act. }\end{array}$} & \multirow[b]{2}{*}{$\begin{array}{r}2007 \\
\text { Act. }\end{array}$} & \multirow[b]{2}{*}{$\begin{array}{r}2008 \\
\text { Act. }\end{array}$} & \multicolumn{3}{|c|}{2009} & \multicolumn{2}{|c|}{2010} \\
\hline & & & & & Budget & $\begin{array}{l}\text { MOF } \\
\text { proj. }\end{array}$ & $\begin{array}{l}\text { Staff } \\
\text { proj. }\end{array}$ & $\begin{array}{r}\text { Draft } \\
\text { budget }\end{array}$ & $\begin{array}{l}\text { Staff } \\
\text { proj. }\end{array}$ \\
\hline & \multicolumn{9}{|c|}{ (In percent of GDP) } \\
\hline Revenues and grants & 17.9 & 18.8 & 17.9 & 19.1 & 18.2 & 15.3 & 15.8 & 14.5 & 15.8 \\
\hline Oil and gas revenues & 5.0 & 6.0 & 4.3 & 5.6 & 4.0 & 2.4 & 3.0 & 2.0 & 3.5 \\
\hline Non-oil and gas revenues & 12.8 & 12.7 & 13.6 & 13.5 & 14.1 & 12.8 & 12.8 & 12.5 & 12.3 \\
\hline Tax revenues & 11.2 & 11.0 & 11.3 & 11.6 & 12.4 & 11.1 & 11.0 & 11.3 & 10.9 \\
\hline Nontax revenues $1 /$ & 1.6 & 1.7 & 2.2 & 1.9 & 1.8 & 1.7 & 1.7 & 1.2 & 1.4 \\
\hline Grants & 0.0 & 0.1 & 0.0 & 0.0 & 0.0 & 0.0 & 0.0 & 0.0 & 0.0 \\
\hline Expenditure and net lending & 18.2 & 19.7 & 19.1 & 19.2 & 19.2 & 18.0 & 18.4 & 15.8 & 17.8 \\
\hline Current expenditure & 11.1 & 10.1 & 9.7 & 10.8 & 10.4 & 9.6 & 10.1 & 8.4 & 9.9 \\
\hline Personnel & 2.0 & 2.2 & 2.3 & 2.3 & 2.6 & 2.6 & 2.6 & 2.7 & 2.7 \\
\hline Subsidies & 4.4 & 3.2 & 3.8 & 5.2 & 3.1 & 2.3 & 2.7 & 1.8 & 3.0 \\
\hline Of which: energy subsidies & 3.4 & 1.9 & 3.0 & 4.2 & 1.9 & 1.2 & 1.7 & 1.1 & 2.0 \\
\hline Interest & 2.4 & 2.4 & 2.0 & 1.8 & 1.9 & 2.0 & 2.0 & 1.9 & 1.9 \\
\hline Other & 2.3 & 2.4 & 1.7 & 1.6 & 2.9 & 2.7 & 2.7 & 2.0 & 2.4 \\
\hline Development expenditure 2/ & 2.3 & 3.1 & 2.9 & 2.6 & 2.8 & 2.8 & 2.7 & 2.6 & 2.8 \\
\hline Transfers to regions & 5.4 & 6.8 & 6.4 & 5.8 & 5.9 & 5.6 & 5.6 & 4.8 & 5.1 \\
\hline Statistical Discrepancy & -0.6 & -0.2 & 0.0 & 0.0 & 0.0 & 0.0 & 0.0 & 0.0 & 0.0 \\
\hline Overall balance & -0.3 & -1.0 & -1.2 & -0.2 & -0.9 & -2.7 & -2.6 & -1.3 & -2.0 \\
\hline Financing & 0.3 & 1.0 & 1.2 & 0.2 & 0.9 & 2.7 & 2.6 & 1.3 & 2.0 \\
\hline Domestic & -0.6 & 1.0 & 1.5 & -0.3 & 1.1 & 2.1 & 2.0 & 1.0 & 1.8 \\
\hline Bank financing & -0.6 & 0.5 & 0.4 & -1.3 & 0.3 & 1.3 & 1.3 & 0.1 & 0.5 \\
\hline Net issuance of government securities & -0.1 & 0.5 & 1.1 & 0.9 & 1.0 & 1.0 & 0.9 & 0.9 & 1.3 \\
\hline Recovery of bank assets $3 /$ & 0.2 & 0.1 & 0.1 & 0.1 & 0.0 & 0.0 & 0.0 & 0.0 & 0.0 \\
\hline Privatization of nonfinancial assets & 0.0 & 0.0 & 0.0 & 0.0 & 0.0 & 0.0 & 0.0 & 0.0 & 0.0 \\
\hline Other & -0.2 & -0.1 & -0.1 & 0.0 & -0.3 & -0.3 & -0.3 & -0.1 & 0.0 \\
\hline External & 0.9 & 0.0 & -0.3 & 0.5 & -0.2 & 0.6 & 0.6 & 0.2 & 0.2 \\
\hline \multicolumn{10}{|l|}{ Memorandum items: } \\
\hline Primary balance & 2.1 & 1.4 & 0.8 & 1.6 & 0.9 & -0.6 & -0.6 & 0.6 & -0.1 \\
\hline General government balance & 0.6 & 0.2 & -1.2 & -0.2 & $\ldots$ & $\ldots$ & -2.6 & $\ldots$ & -2.1 \\
\hline Non-oil primary balance & -2.9 & -4.6 & -3.5 & -4.0 & -3.1 & -3.1 & -3.6 & -1.4 & -3.6 \\
\hline Public debt to GDP & 46.3 & 39.0 & 35.1 & 33.2 & $\ldots$ & $\ldots$ & 31.1 & $\ldots$ & 31.0 \\
\hline
\end{tabular}

Sources: Data provided by the Indonesian authorities; and Fund staff estimates.

1/ From 2004 onwards, deposit insurance premia are treated as nontax revenues.

2/ From 2005 onwards, comprises capital spending and social assistance spending.

3/ Includes capitalization of deposit insurance company in 2005. 
Table 6. Indonesia: Selected Vulnerability Indicators, 2005-09

\begin{tabular}{|c|c|c|c|c|c|c|}
\hline & 2005 & 2006 & 2007 & 2008 & $20091 /$ & $\begin{array}{r}\text { Latest } \\
\text { Observation }\end{array}$ \\
\hline \multicolumn{7}{|l|}{ Key economic and market indicators } \\
\hline Real GDP growth (in percent) & 5.7 & 5.5 & 6.3 & 6.1 & 3.5 & Proj. \\
\hline $\mathrm{CPI}$ inflation (in percent) & 17.1 & 6.6 & 5.6 & 11.1 & 6.0 & May-09 \\
\hline Short-term (ST) interest rate (in percent) & 12.8 & 9.8 & 8.0 & 11.0 & 7.0 & Jun-09 \\
\hline EMBI secondary market spread (bps, end of period) & 269 & 153 & 275 & 381 & 371 & Jun-09 \\
\hline Exchange rate NC/US\$ (end of period) & 9,830 & 8,990 & 9,395 & 10,900 & 10,128 & Jun-09 \\
\hline \multicolumn{7}{|l|}{ External sector } \\
\hline Exchange rate regime & \multicolumn{6}{|c|}{ (Float) } \\
\hline Current account balance (percent of GDP) & 0.1 & 3.0 & 2.4 & 0.1 & 0.3 & Proj. \\
\hline Net FDI inflows (percent of GDP) & 1.8 & 0.6 & 0.5 & 0.4 & 0.6 & Proj. \\
\hline Exports (percentage change of US\$ value, GNFS) & 20.7 & 15.1 & 13.4 & 18.7 & -26.9 & Proj. \\
\hline Real effective exchange rate (end period; Jan. $2000=100$ ) & 124.8 & 134.8 & 127.3 & 118.4 & 122.4 & May-09 \\
\hline Gross international reserves (GIR) in US\$ billion & 34.7 & 42.6 & 56.9 & 51.6 & 57.9 & May-09 \\
\hline GIR in percent of ST debt at remaining maturity (RM) & 129.6 & 153.6 & 179.9 & 140.2 & 197.6 & Proj. \\
\hline Total gross external debt (ED) in percent of GDP & 46.2 & 35.5 & 31.8 & 29.3 & 29.4 & Proj. \\
\hline Of which: ST external debt (original maturity, in percent of total ED) & 5.5 & 6.5 & 10.3 & 5.4 & 5.3 & Proj. \\
\hline ED of domestic private sector (in percent of total ED) & 42.3 & 47.4 & 49.3 & 47.8 & 46.1 & Proj. \\
\hline ED to foreign official sector (in percent of total ED) & 54.0 & 48.1 & 45.5 & 44.7 & 43.8 & Proj. \\
\hline Total gross external debt in percent of exports of GNFS & 132.3 & 112.6 & 105.3 & 96.7 & 135.1 & Proj. \\
\hline Gross external financing requirement (US\$ billion) 2/ & 24.0 & 19.0 & 18.3 & 37.1 & 29.4 & Proj. \\
\hline \multicolumn{7}{|l|}{ Public sector (PS) 3/ } \\
\hline Overall balance (percent of GDP) & -0.3 & -1.0 & -1.2 & -0.2 & -2.6 & Proj. \\
\hline Primary balance (percent of GDP) & 2.1 & 1.4 & 0.8 & 1.6 & -0.6 & Proj. \\
\hline Gross PS financing requirement (in percent of GDP) 4/ & 3.2 & 3.4 & 3.6 & 2.1 & 4.8 & Proj. \\
\hline Public sector gross debt (PSGD, in percent of GDP) & 45.8 & 39.0 & 35.1 & 33.2 & 31.1 & Proj. \\
\hline Of which: Exposed to rollover risk (in percent of total PSGD) 5/ & 4.3 & 6.0 & 2.4 & 1.9 & 2.1 & Proj. \\
\hline Exposed to exchange rate risk (in percent of total PSGD) 6/ & 51.1 & 46.1 & 47.0 & 51.6 & 48.9 & Proj. \\
\hline Exposed to interest rate risk (in percent of total PSGD) 7/ & 16.6 & 15.7 & 12.4 & 9.2 & 8.4 & Proj. \\
\hline \multicolumn{7}{|l|}{ Financial sector (FS) } \\
\hline Capital adequacy ratio (in percent) & 19.3 & 21.3 & 19.3 & 16.8 & 17.8 & Apr-09 \\
\hline NPLs in percent of total loans $8 /$ & 7.6 & 6.1 & 4.1 & 3.2 & 4.1 & Apr-09 \\
\hline Provisions in percent of NPLs & 82.2 & 99.7 & 120.5 & 153.0 & 132.4 & Apr-09 \\
\hline Return on assets (in percent) & 2.6 & 2.6 & 2.8 & 2.3 & 2.7 & Apr-09 \\
\hline Return on equity (in percent) & 32.3 & 33.2 & 28.5 & 24.6 & 17.4 & Apr-09 \\
\hline FX deposits (in percent of total deposits) & 13.1 & 15.5 & 15.6 & 17.4 & 16.9 & Apr-09 \\
\hline FX loans (in percent of total loans) & 16.0 & 18.8 & 20.3 & 18.7 & 16.5 & Apr-09 \\
\hline Government debt held by FS ( percent of total FS assets) & 21.9 & 18.5 & 15.7 & 13.1 & 13.5 & Apr-09 \\
\hline Credit to private sector (percent change) & 19.7 & 12.8 & 25.7 & 30.6 & 21.4 & Apr-09 \\
\hline
\end{tabular}

1/ Staff estimates, projections, or latest available observations as indicated in the last column.

2/ Current account deficit plus amortization of external debt.

3/ Public sector covers central government.

4/ Overall balance plus debt amortization.

5/ Short-term debt and maturing medium- and long-term debt, domestic and external, excluding external debt to official creditors.

6/ Debt in foreign currency or linked to the exchange rate, domestic and external, excluding external debt on concessional terms.

7/ Short-term debt and maturing medium- and long-term debt at variable interest rates for domestic debt. Information on external debt is not available.

8/ Loans are gross of any allowance for losses. 
Table 7. Indonesia: Medium-Term Macroeconomic Framework, 2008-14

\begin{tabular}{|c|c|c|c|c|c|c|c|}
\hline & 2008 & 2009 & 2010 & 2011 & 2012 & 2013 & 2014 \\
\hline & Act. & \multicolumn{6}{|c|}{ Proj. } \\
\hline Real GDP (percent change) & 6.1 & 3.5 & 4.5 & 5.0 & 5.5 & 6.0 & 6.3 \\
\hline Domestic demand & 7.7 & 4.9 & 5.5 & 5.7 & 5.9 & 6.2 & 6.5 \\
\hline \multicolumn{8}{|l|}{ Of which: } \\
\hline Private consumption & 5.3 & 4.9 & 5.1 & 5.3 & 5.7 & 5.9 & 6.1 \\
\hline Gross fixed investment & 11.7 & 3.2 & 7.6 & 7.0 & 7.3 & 7.6 & 8.1 \\
\hline Change in stocks $1 /$ & 0.2 & 0.0 & 0.0 & 0.0 & 0.0 & 0.0 & 0.0 \\
\hline Net exports $1 /$ & 0.7 & -0.9 & -0.5 & -0.2 & 0.1 & 0.3 & 0.3 \\
\hline Statistical discrepancy $1 /$ & -1.4 & 0.0 & 0.0 & 0.0 & 0.0 & 0.0 & 0.0 \\
\hline \multicolumn{8}{|l|}{ Saving and investment (in percent of GDP) } \\
\hline Gross investment 2/ & 27.6 & 26.9 & 27.7 & 28.1 & 28.6 & 29.0 & 29.5 \\
\hline Gross national saving & 27.7 & 27.2 & 27.2 & 27.5 & 27.8 & 28.1 & 28.4 \\
\hline Foreign saving (external current account balance) & -0.1 & -0.3 & 0.4 & 0.7 & 0.8 & 0.9 & 1.0 \\
\hline \multicolumn{8}{|l|}{ Prices (12-month percent change) } \\
\hline Consumer prices (end period) & 11.1 & 5.0 & 5.5 & 4.5 & 4.0 & 3.8 & 3.6 \\
\hline Consumer prices (period average) & 9.8 & 5.6 & 6.3 & 4.9 & 4.2 & 3.9 & 3.7 \\
\hline \multicolumn{8}{|l|}{ Public finances (in percent of GDP) } \\
\hline Central government revenue & 19.1 & 15.8 & 15.8 & 15.9 & 15.9 & 15.7 & 15.6 \\
\hline Central government expenditure & 19.2 & 18.4 & 17.8 & 17.7 & 17.6 & 17.3 & 17.1 \\
\hline Central government balance & -0.2 & -2.6 & -2.0 & -1.8 & -1.7 & -1.6 & -1.5 \\
\hline Primary balance & 1.6 & -0.6 & -0.1 & 0.1 & 0.2 & 0.3 & 0.3 \\
\hline Central government debt & 33.2 & 31.1 & 31.0 & 30.4 & 29.8 & 29.1 & 28.3 \\
\hline \multicolumn{8}{|l|}{ Balance of payments (US\$ billions) } \\
\hline Oil and gas (net) & 7.8 & 7.4 & 6.7 & 5.7 & 4.2 & 2.7 & 1.0 \\
\hline Non-oil exports (f.o.b) & 107.9 & 80.0 & 81.7 & 88.5 & 97.3 & 107.7 & 118.9 \\
\hline Non-oil imports (f.o.b) & -92.8 & -66.1 & -69.9 & -76.6 & -83.9 & -92.7 & -102.2 \\
\hline Current account balance & 0.3 & 1.4 & -2.4 & -4.2 & -5.3 & -6.4 & -7.9 \\
\hline Direct foreign investment & 2.0 & 3.0 & 2.6 & 3.0 & 3.3 & 3.6 & 4.0 \\
\hline Overall balance & -5.3 & 10.4 & 3.0 & 2.2 & 2.1 & 3.4 & 3.2 \\
\hline \multicolumn{8}{|l|}{ Gross reserves } \\
\hline In billions of U.S. dollars (end period) & 51.6 & 62.1 & 65.1 & 67.3 & 69.3 & 71.7 & 72.9 \\
\hline In months of imports & 6.0 & 6.8 & 6.5 & 6.2 & 5.8 & 5.5 & 5.5 \\
\hline As a percent of short-term debt $3 /$ & 140.2 & 197.6 & 194.8 & 182.3 & 172.2 & 157.1 & 154.4 \\
\hline \multicolumn{8}{|l|}{ Total external debt } \\
\hline In billions of U.S. dollars & 149.7 & 153.0 & 157.5 & 161.8 & 164.9 & 167.7 & 168.5 \\
\hline In percent of GDP & 29.3 & 29.4 & 27.5 & 26.3 & 24.8 & 23.3 & 21.5 \\
\hline \multicolumn{8}{|l|}{ Memorandum items: } \\
\hline Oil production (000bcpd) & 927 & 960 & 965 & 970 & 970 & 974 & 979 \\
\hline Indonesian oil price (US\$/bbl) & 96.6 & 60.1 & 74.1 & 77.6 & 79.6 & 80.9 & 82.1 \\
\hline Nominal GDP (US\$ billions) & 512 & 520 & 572 & 615 & 665 & 721 & 782 \\
\hline
\end{tabular}

Sources: Data provided by the Indonesian authorities; and Fund staff estimates.

1/ Contribution to GDP growth.

$2 /$ Includes changes in stocks.

3/ Short-term debt on a remaining maturity basis. 


\section{APPENDIX I: Indonesia—PUblic ANd EXTERnal Debt SustainabiLITY}

\section{A. Public Debt}

1. Public sector debt has declined as a share of GDP since 2000. The ratio fell to a post-crisis record-low level of 33 percent in 2008 (Figure I.1) owing to prudent fiscal management, which led to primary surpluses averaging almost 2 percent of GDP per year in the last decade. Reduced risk premia, lower interest rates, and high real GDP growth also contributed to debt consolidation. Foreign-currency debt (mostly due to multilateral institutions) has fallen markedly to about half of total debt, as the improved fiscal position facilitated government access to the domestic capital market.

2. In the baseline scenario, a moderate further decline in public sector debt is likely. Despite a larger fiscal deficit, public debt is projected to fall to about 31 percent of GDP in 2009, reflecting rupiah appreciation and falling interest rates. In the medium term, the public debt-to-GDP ratio is expected to decline gradually to $28 \frac{1}{2}$ percent by 2014 . Strong growth from 2011 and sustained fiscal prudence drive this result. A return to positive primary balances from 2011 is consistent with accommodating extra resources for development spending.

3. Standard stress tests suggest that the projected decline in the debt ratio could be vulnerable to contingent liabilities, sharp exchange rate movements, and higher interest rates (Figure I.1). Fiscal contingent liabilities amounting to 10 percent of GDP could raise the public sector debt to almost 38 percent of GDP by 2014, with the ratio above 40 percent in 2010 (a level not seen since 2005). A 30 percent currency depreciation would raise the debt ratio by 9 percentage points compared to the baseline. A large increase in real interest rates would have smaller, but still sizeable, effects with the debt ratio reaching 33 percent by 2014. Other macroeconomic shocks have a more limited impact.

\section{B. External Debt}

4. Indonesia's external debt has also declined steadily, from over 150 percent of GDP in 1998 to 29 percent in 2008 (Figure I.2). External debt as a percentage of exports has also declined, from 288 percent to 97 percent, over the same period.

5. In the baseline scenario, the external debt dynamics are projected to be sustainable. The debt-to-GDP ratio is projected to decline to around 22 percent by 2014; the main driving factors are: (i) the projected increase in real GDP growth to 5-61/4 percent over the medium term; (ii) a projected positive growth-interest rate differential; and (iii) an expected increase in nondebt-creating capital inflows. The favorable trend in external debt may be reversed if these expected positive developments do not occur.

6. The external debt ratio is most vulnerable to shocks to the exchange rate. A one-time 30 percent real exchange rate depreciation would raise the debt ratio by 14 percentage points in 2010, with the impact falling to 12 percentage points over the baseline by 2014 . 
Figure I.1. Indonesia: Public Debt Sustainability: Bound Tests 1/

(Public debt in percent of GDP)
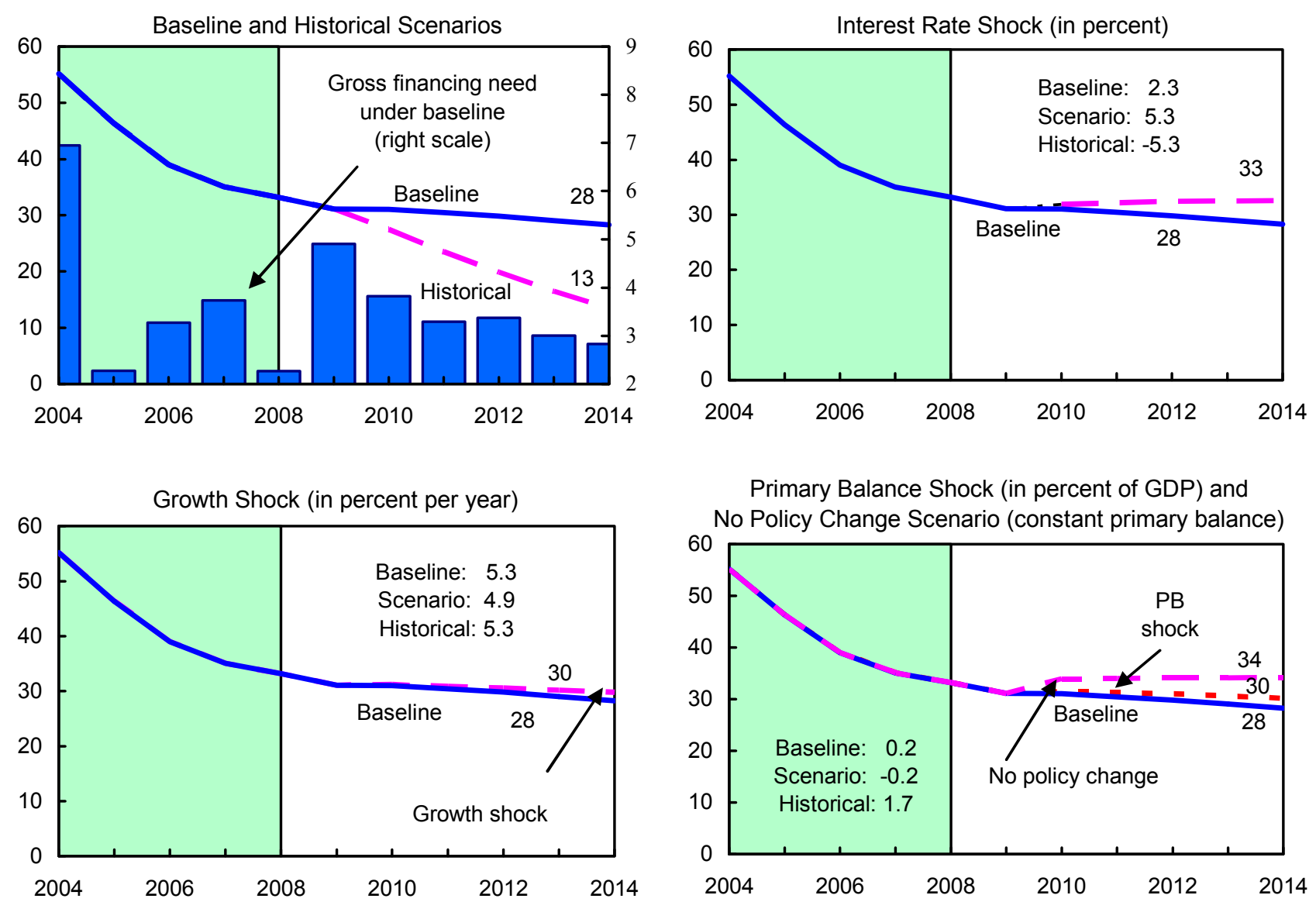

Primary Balance Shock (in percent of GDP) and No Policy Change Scenario (constant primary balance)
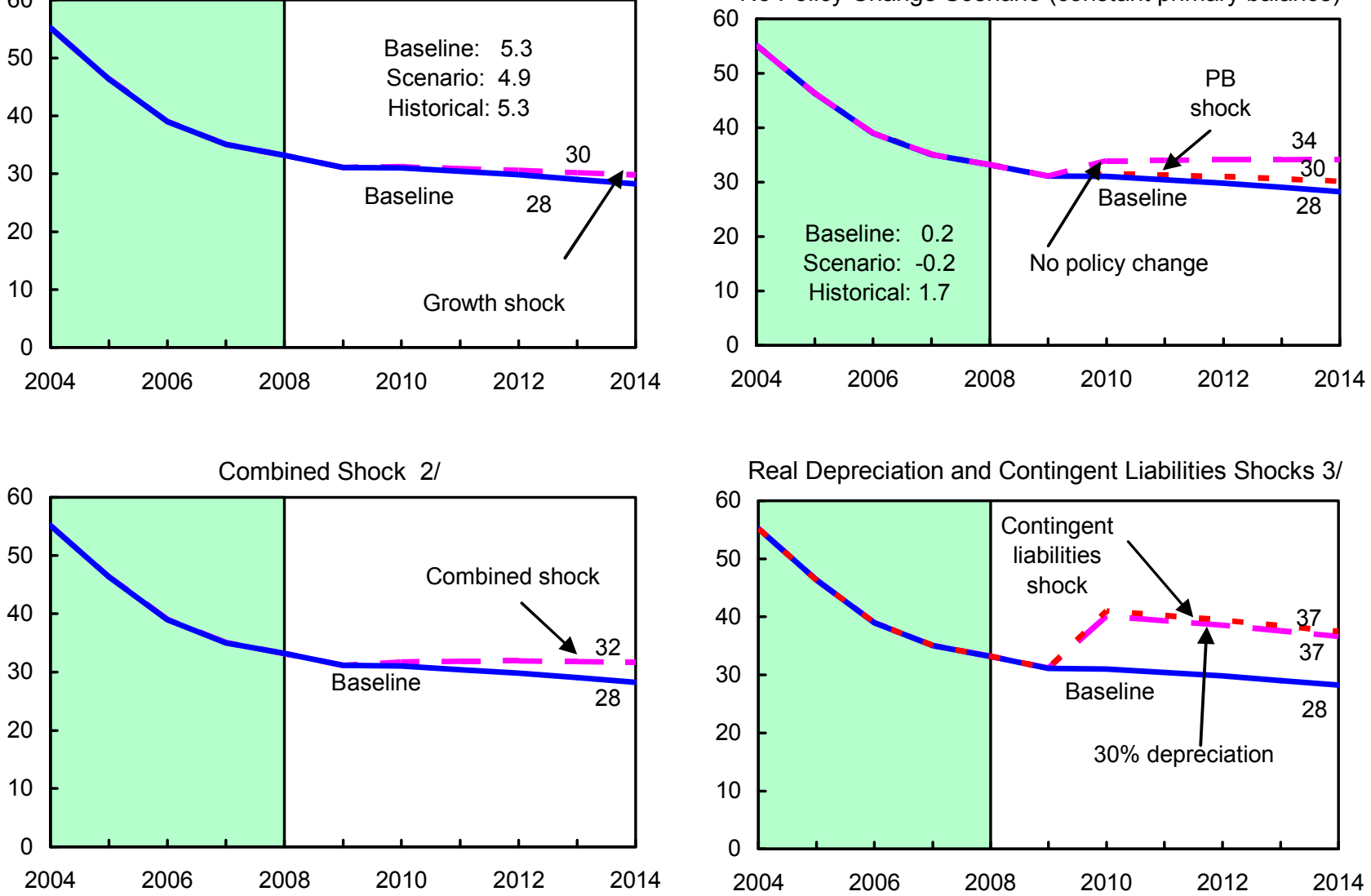

Real Depreciation and Contingent Liabilities Shocks 3/

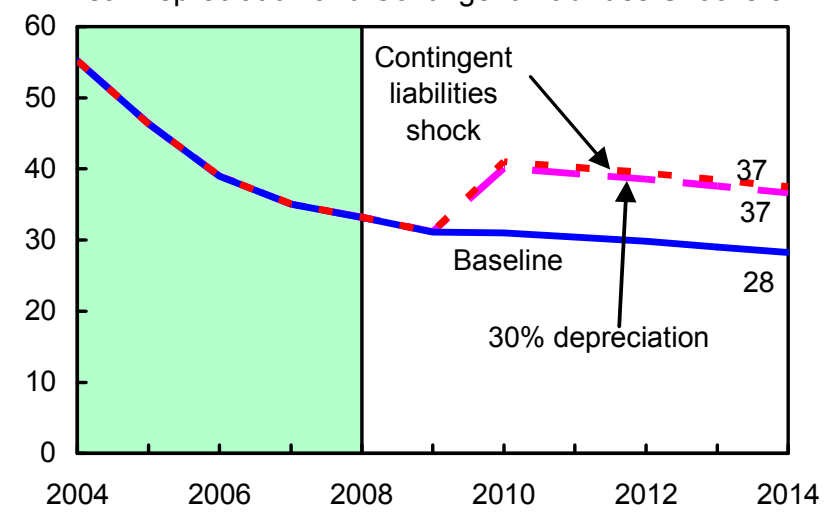

Sources: International Monetary Fund, country desk data, and staff estimates.

1/ Shaded areas represent actual data. Individual shocks are permanent one-half standard deviation shocks. Figures in the boxes represent average projections for the respective variables in the baseline and scenario being presented. Ten-year historical average for the variable is also shown.

2/ Permanent $1 / 4$ standard deviation shocks applied to real interest rate, growth rate, and primary balance.

3/ One-time real depreciation of 30 percent and 10 percent of GDP shock to contingent liabilities occur in 2009, with real depreciation defined as nominal depreciation (measured by percentage fall in dollar value of local currency) minus domestic inflation (based on GDP deflator). 
Table I.1. Indonesia: Public Sector Debt Sustainability Framework, 2004-2014

(In percent of GDP, unless otherwise indicated)

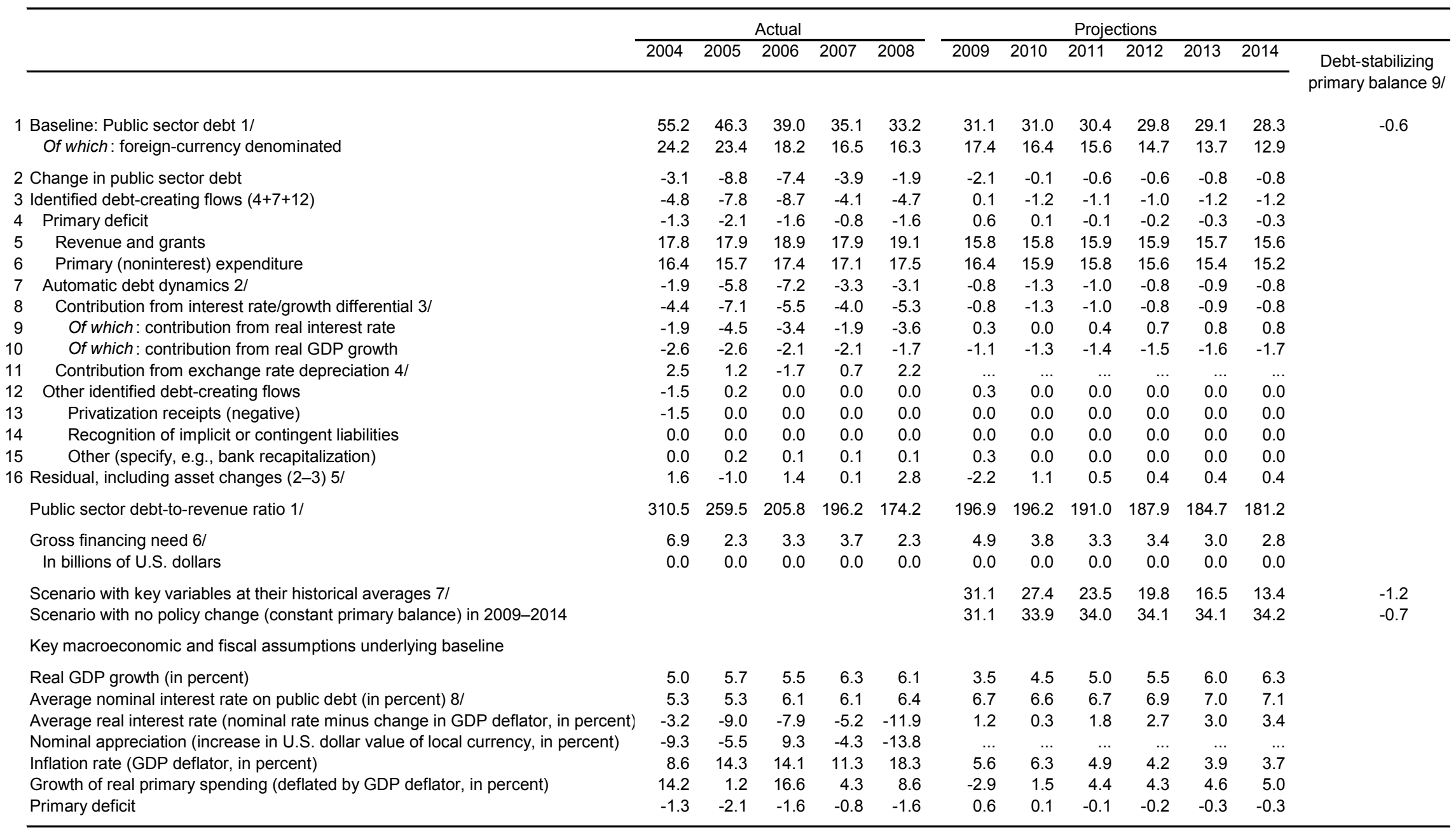

$1 /$ Indicate coverage of public sector, e.g., general government or nonfinancial public sector. Also whether net or gross debt is used.

$2 /$ Derived as $[(r-\pi(1+g)-g+\alpha \varepsilon(1+r)] /(1+g+\pi+g \pi))$ times previous period debt ratio, with $r=$ interest rate; $\pi=$ growth rate of GDP deflator; $g=$ real GDP growth rate; $\alpha=$ share of foreign-

currency denominated debt; and $\mathrm{e}=$ nominal exchange rate depreciation (measured by increase in local currency value of U.S. dollar).

$3 /$ The real interest rate contribution is derived from the denominator in footnote $2 /$ as $r-\pi(1+g)$ and the real growth contribution as $-g$.

$4 /$ The exchange rate contribution is derived from the numerator in footnote $2 /$ as $\alpha \varepsilon(1+r)$.

$5 /$ For projections, this line includes exchange rate changes.

6/ Defined as public sector deficit, plus amortization of medium and long-term public sector debt, plus short-term debt at end of previous period.

7/ The key variables include real GDP growth; real interest rate; and primary balance in percent of GDP.

8/ Derived as nominal interest expenditure divided by previous period debt stock.

9/ Assumes that key variables (real GDP growth, real interest rate, and other identified debt-creating flows) remain at the level of the last projection year. 
Figure I.2. Indonesia: External Debt Sustainability: Bound Tests 1/

(External debt in percent of GDP)
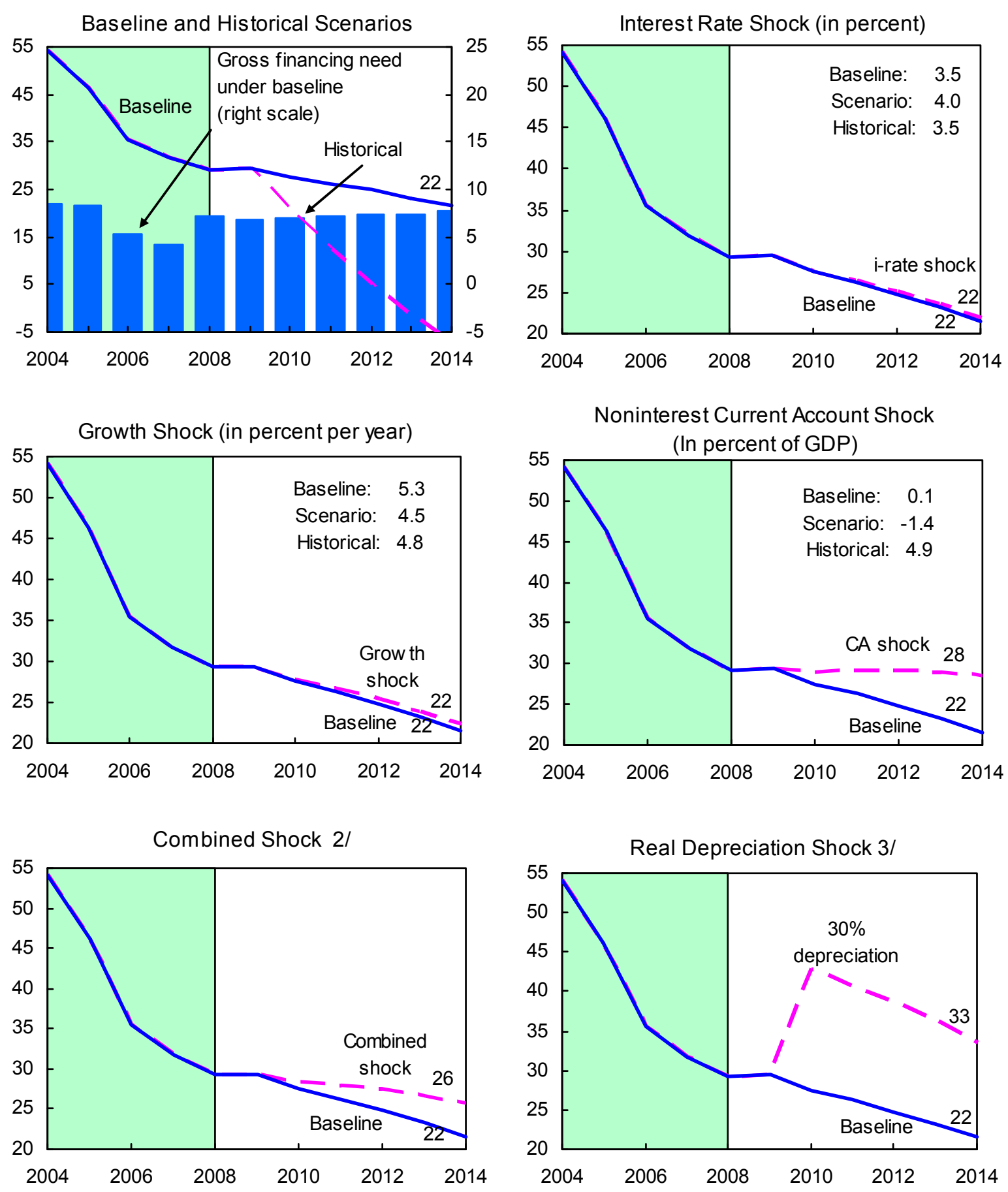

Sources: International Monetary Fund, Country desk data, and staff estimates.

1/ Shaded areas represent actual data. Individual shocks are permanent one-half standard deviation shocks. Figures in the boxes represent average projections for the respective variables in the baseline and scenario being presented. Ten-year historical average for the variable is also show $\mathrm{n}$.

2/ Permanent 1/4 standard deviation shocks applied to real interest rate, grow th rate, and current account balance.

3/ One-time real depreciation of 30 percent occurs in 2009. 
Table I.2. Indonesia: External Debt Sustainability Framework, 2004-2014

(In percent of GDP, unless otherwise indicated)

\begin{tabular}{|c|c|c|c|c|c|c|c|c|c|c|c|c|}
\hline & \multicolumn{5}{|c|}{ Actual } & \multicolumn{7}{|c|}{ Projections } \\
\hline & 2004 & 2005 & 2006 & 2007 & 2008 & 2009 & 2010 & 2011 & 2012 & 2013 & 2014 & \multirow{2}{*}{$\begin{array}{c}\text { Debt-stabilizing } \\
\text { noninterest current } \\
\text { account } 6 /\end{array}$} \\
\hline & & & & & & & & & & & & \\
\hline 1 Baseline: External debt & 54.1 & 46.2 & 35.5 & 31.8 & 29.3 & 29.4 & 27.5 & 26.3 & 24.8 & 23.3 & 21.5 & -1.8 \\
\hline 2 Change in external debt & -4.4 & -7.9 & -10.7 & -3.7 & -2.5 & 0.2 & -1.9 & -1.3 & -1.5 & -1.5 & -1.7 & \\
\hline 3 Identified external debt-creating flows $(4+8+9)$ & -6.0 & -7.2 & -14.0 & -9.5 & -5.4 & -2.0 & -1.4 & -1.2 & -1.2 & -1.2 & -1.2 & \\
\hline 4 Current account deficit, excluding interest payments & -2.0 & -1.8 & -4.3 & -3.5 & -0.9 & -1.0 & -0.3 & -0.2 & -0.1 & 0.0 & 0.2 & \\
\hline Deficit in balance of goods and services & -4.4 & -2.9 & -5.4 & -51.9 & -52.1 & -36.0 & -34.4 & -34.4 & -34.5 & -34.6 & -34.7 & \\
\hline Exports & 32.2 & 35.0 & 31.6 & 30.2 & 30.3 & 21.8 & 20.7 & 20.6 & 20.5 & 20.5 & 20.5 & \\
\hline Imports & 27.8 & 32.0 & 26.1 & -21.7 & -21.8 & -14.3 & -13.8 & -13.8 & -13.9 & -14.1 & -14.2 & \\
\hline Net nondebt creating capital inflows (negative) & -0.3 & -1.6 & -1.0 & -1.5 & -0.4 & -0.8 & -0.7 & -0.6 & -0.6 & -0.7 & -0.8 & \\
\hline Automatic debt dynamics $1 /$ & -3.6 & -3.8 & -8.6 & -4.5 & -4.1 & -0.2 & -0.5 & -0.4 & -0.4 & -0.5 & -0.5 & \\
\hline Contribution from nominal interest rate & 1.4 & 1.7 & 1.3 & 1.0 & 0.8 & 0.8 & 0.7 & 0.9 & 0.9 & 0.9 & 0.8 & \\
\hline Contribution from real GDP growth & -2.7 & -2.8 & -2.0 & -1.9 & -1.6 & -1.0 & -1.2 & -1.3 & -1.3 & -1.4 & -1.4 & \\
\hline 2 Contribution from price and exchange rate changes $2 /$ & -2.4 & -2.7 & -8.0 & -3.7 & -3.3 & $\ldots$ & $\ldots$ & $\ldots$ & $\ldots$ & $\ldots$ & $\ldots$ & \\
\hline 3 Residual, including change in gross foreign assets $(2-3) 3 /$ & 1.5 & -0.7 & 3.3 & 5.7 & 2.9 & 2.2 & -0.4 & -0.1 & -0.3 & -0.3 & -0.6 & \\
\hline External debt-to-exports ratio (in percent) & 168.0 & 132.3 & 112.6 & 105.3 & 96.7 & 135.1 & 133.2 & 127.8 & 120.9 & 113.3 & 105.1 & \\
\hline Gross external financing need (in billions of U.S. dollars) 4/ & 21.8 & 24.0 & 19.0 & 18.3 & 37.1 & 29.4 & 33.8 & 37.7 & 42.2 & 46.7 & 53.5 & \\
\hline In percent of GDP & 8.5 & 8.4 & 5.2 & 4.2 & 7.3 & 5.7 & 5.9 & 6.1 & 6.3 & 6.5 & 6.8 & \\
\hline Scenario with key variables at their historical averages 5 / & & & & & & 29.4 & 20.7 & 12.6 & 5.3 & -1.3 & -7.2 & -0.3 \\
\hline \multicolumn{13}{|l|}{ Key macroeconomic assumptions underlying baseline } \\
\hline Real GDP growth (in percent) & 5.0 & 5.7 & 5.5 & 6.3 & 6.1 & 3.5 & 4.5 & 5.0 & 5.5 & 6.0 & 6.3 & \\
\hline GDP deflator in U.S. dollars (change in percent) & 4.2 & 5.2 & 20.8 & 11.6 & 11.7 & -1.8 & 5.2 & 2.5 & 2.4 & 2.3 & 2.1 & \\
\hline Nominal external interest rate (in percent) & 2.6 & 3.4 & 3.7 & 3.5 & 3.1 & 2.6 & 2.8 & 3.4 & 3.9 & 3.8 & 3.8 & \\
\hline Growth of exports (U.S. dollar terms, in percent) & 19.8 & 20.7 & 15.1 & 13.4 & 18.7 & -26.9 & 4.4 & 7.1 & 7.8 & 8.5 & 8.3 & \\
\hline Growth of imports (U.S. dollar terms, in percent) & 26.9 & 28.0 & 4.1 & -198.3 & 19.1 & -33.5 & 5.9 & 8.1 & 8.9 & 9.6 & 9.4 & \\
\hline Current account balance, excluding interest payments & 2.0 & 1.8 & 4.3 & 3.5 & 0.9 & 1.0 & 0.3 & 0.2 & 0.1 & 0.0 & -0.2 & \\
\hline Net non-debt creating capital inflows & 0.3 & 1.6 & 1.0 & 1.5 & 0.4 & 0.8 & 0.7 & 0.6 & 0.6 & 0.7 & 0.8 & \\
\hline
\end{tabular}

1/ Derived as $[r-g-r(1+g)+e a(1+r)] /(1+g+r+g r)$ times previous period debt stock, with $r=$ nominal effective interest rate on external debt; $r=$ change in domestic GDP deflator in US dollar terms, $g=$ real GDP growth rate, $\mathrm{e}=$ nominal appreciation (increase in dollar value of domestic currency), and $\mathrm{a}=$ share of domestic-currency denominated debt in total external debt.

$2 /$ The contribution from price and exchange rate changes is defined as $[-r(1+g)+e a(1+r)] /(1+g+r+g r)$ times previous period debt stock. $r$ increases with an appreciating domestic currency (e $>0$ ) and rising inflation (based on GDP deflator)

$3 /$ For projection, line includes the impact of price and exchange rate changes.

4/ Defined as current account deficit, plus amortization on medium- and long-term debt, plus short-term debt at end of previous period.

5/ The key variables include real GDP growth; nominal interest rate; dollar deflator growth; and both non-interest current account and non-debt inflows in percent of GDP.

6/ Long-run, constant balance that stabilizes the debt ratio assuming that key variables (real GDP growth, nominal interest rate, dollar deflator growth, and non-debt inflows in percent of GDP) remain at their levels of the last projection year. 


\section{INTERNATIONAL MONETARY FUND}

\section{INDONESIA}

\section{Staff Report for the 2009 Article IV Consultation-Informational Annex}

Prepared by the Asia and Pacific Department

June 30, 2009

Contents

Page

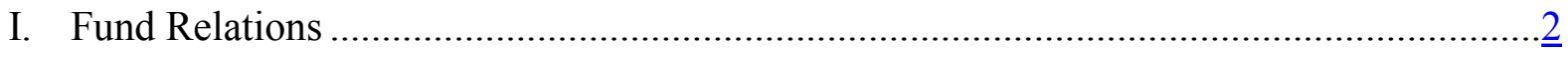

II. Relations with the World Bank Group.........................................................................

III. Relations with the Asian Development Bank .................................................................

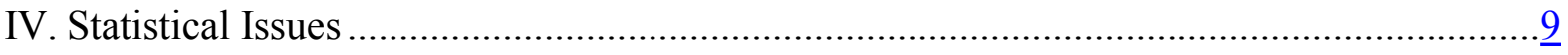




\section{ANNEX I: INDONESIA-FUND RELATIONS}

(As of May 31, 2009)

I. Membership Status: Joined February 21, 1967; Article VIII

II. General Resources Account

Quota

Fund holdings of currency

Reserve position in Fund

III. SDR Department

Net cumulative allocation

Holdings

IV. Outstanding Purchases and Loans

V. Financial Arrangements

$\begin{array}{lcccc}\text { Type } & \text { Approval Date } & \begin{array}{c}\text { Amount } \\ \text { Date }\end{array} & \begin{array}{c}\text { Approved } \\ \text { (SDR millions) }\end{array} & \begin{array}{c}\text { Amount Drawn } \\ \text { (SDR millions) }\end{array} \\ \text { EFF } & 2 / 04 / 2000 & 12 / 31 / 2003 & 3,638.00 & 3,638.00 \\ \text { EFF } & 8 / 25 / 1998 & 2 / 04 / 2000 & 5,383.10 & 3,797.70 \\ \text { Stand-by } & 11 / 05 / 1997 & 8 / 25 / 1998 & 8,338.24 & 3,669.12\end{array}$

VI. Projected Payments to Fund (expectations basis)

(SDR millions; based on existing use of resources and present holdings of SDRs):

\begin{tabular}{lccccr} 
& \multicolumn{5}{c}{ Forthcoming } \\
\cline { 2 - 6 } & $\mathbf{2 0 0 9}$ & $\mathbf{2 0 1 0}$ & $\mathbf{2 0 1 1}$ & $\mathbf{2 0 1 2}$ & $\mathbf{2 0 1 3}$ \\
Principal & & & & & \\
Charges/Interest & 0.50 & 1.02 & 1.02 & 1.02 & 1.02 \\
$\quad$ Total & 0.50 & 1.02 & 1.02 & 1.02 & 1.02
\end{tabular}

VII. Exchange Arrangements

The rupiah has floated since August 14, 1997. The market exchange rate was Rp 10,270 per U.S. dollar on June 29, 2009. Indonesia has accepted the obligations of Article VIII, Sections 2, 3, and 4, and maintains an exchange system free of restrictions on payments and transfers for current international transactions.

\section{Article IV Consultation}

The last Article IV consultation report (Country Report No. 08/299) was discussed by the Executive Board on May 28, 2008.

CInternational Monetary Fund. Not for Redistribution 


\section{ANNEX II. INDONESIA-RELATIONS WITH THE WORLD BANK GROUP}

(As of June 18, 2009)

\section{Indonesia Country Partnership Strategy}

The World Bank Group's (WBG) Country Partnership Strategy (CPS) for Indonesia for FY2009-12, which marked Indonesia's emergence as a strong middle income country, was approved by the WBG Board in September 2008. The CPS focuses on improving Indonesia's institutions, both at the central and sub-national level, through five core areas of engagement: private sector development, infrastructure, community development, education, environmental sustainability, and disaster mitigation.

CPS implementation is progressing apace, marked by strong dialogue and solid partnership with the Indonesia's core economic ministries and several line ministries and agencies, including education, public works, people's welfare, anti-corruption commission (KPK), and supreme and state audit agencies (BPK and BPKP). The engagements with regional/local counterparts including in Aceh, Papua, Central Java and Jakarta, are broadening. In addition, a major effort to engage more seriously with civil society, academia and media has been launched. Partnerships with the key bilateral and multilaterals, including EC, Japan, Australia, Netherlands, ADB, UNDP and IMF remain robust.

\section{World Bank Engagement: Selected Highlights}

Supporting Indonesia's Efforts to Mitigate the Impact of the Global Financial Crisis. Only a few months into the implementation of the new CPS, Indonesia encountered the growing global financial crisis. The Government of Indonesia (GOI) has taken precautionary and preemptive actions to address financial and fiscal concerns including approaching the WBG and other development partners for financing support in a difficult environment. The WBG has helped the Government mobilize contingent financing, including from bilateral, multilateral and other sources, of US\$5.5 billion, of which US\$2 billion is in a WBG - supported Development Policy Loan with a Deferred Drawdown Option (DPL-DDO). Through adoption of a robust platform of reforms aimed at strengthening its resilience, Indonesia is not only expected to weather the current crisis, but also emerge stronger in its aftermath.

Strengthening the Governance Agenda. The WBG under the new CPS is supporting the strengthening of Indonesia's country systems. The fight against corruption is central to the Government's program and relevant institutions continue to be strengthened. Although progress is being made, challenges remain, as epitomized by slow progress on implementing the legal and judicial reform agenda. The CPS seeks to move away from a WBG focused approach of "ring-fencing projects" to one designed to strengthen and build upon Indonesia's own systems, policies and procedures. This approach focuses on policy formulation, policy 
and program implementation, financial management, procurement, budget implementation, audit, social and environmental safeguards, monitoring and evaluation, and supports Indonesia's priority budget programs to enhance the quality of overall public spending.

Deepening Indonesia's Decentralization. The decentralization and empowerment of local governments has been one of Indonesia's most remarkable achievements in the past 10 years. As a result, Indonesia's almost 500 sub-national governments now manage close to $40 \%$ of all public spending. Many of elected heads of provinces and districts/cities are implementing innovative reforms, although challenges are considerable. Needs, opportunities and the WBG's capacity to respond to the demand vary greatly across the archipelago. Over the CPS period, the WBG will seek to engage with a limited number of sub-national governments that demonstrate a clear commitment to reforms through the Public Expenditure Analysis and Capacity Harmonization (PEACH) program. PEACH programs focus on local planning and budgeting and are demand-driven, tailored to the needs of local governments and implemented by them, together with local Indonesian research institutions. In addition, the WBG has re-structured several Bank financed local government support programs, to expedite their progress and resolve implementation bottlenecks. Lastly, the WBG-administered Decentralization Support Facility brings together a number of development partners with a broad mandate to engage Indonesian institutions essential to the local accountability framework, such as legislatures, media and NGO networks.

Enhancing Poverty Reduction and Sustainable Growth. The WBG is supporting comprehensive policy reforms and innovative investment programs to support Government's poverty reduction and sustainable growth programs. Learning from the effectiveness of successful engagements, such as the decade-long well performing Kecamatan Development Project or KDP, the world's largest program that uses the Community-Driven Development approach, and the Urban Poverty Project (UPP), the WBG - supported operations in this area have expanded, including support to the National Community Empowerment Program - PNPM. Such operations build on what has worked well, focus on mechanisms for social accountability, promote external transparency and access to information, enhance planning and budgeting capacity, and integrate AAA/Trust Funds with lending and supervision. Recent major operations also include a series of development program loans (DPLs and Infrastructure DPLs) in support of the government's reform program to improve the investment climate, public financial management, public service delivery and infrastructure. Investment projects support, among others, the School AssistanceBOS-KITA program to better manage education funding and Indonesia Infrastructure Finance Facility for infrastructure funding.

\section{Supporting Indonesia's Emerging Regional and International Role on Environmental} Sustainability and Climate Change. Indonesia emits significant levels of greenhouse gases, mainly from deforestation and land use change. The GOI recognizes this issue and is developing an initiative on Reduced Emissions from Deforestation and Degradation (REDD) 
supported by the WBG. Indonesia achieved global visibility as host of the United Nations Framework Convention on Climate Change (UNFCCC)'s Conference of Parties (COP) - 13 in 2007 and is now working together with Poland and Denmark toward COP 14.

The GOI is pursuing an innovative and potentially path-breaking engagement with the WBG on geothermal energy. The WBG is also deepening the relationships established with the National Planning Agency (Bappenas) and the local governments of Aceh, Nias and Jogjakarta in supporting selected elements of the Government's actions to strengthen natural disaster resiliency. In addition to investment operations, the WBG is supporting the GOI with background studies and other analytical work and technical assistance provided to the Government agencies at the central and local levels. One example of such support is the provision of technical assistance to the Ministry of Public Works to support development and implementation of the master plan for peatland rehabilitation in South Kalimantan.

Support for Sustainable Recovery of Aceh, Nias and Yogyakarta. Reconstruction efforts after the tsunami in Aceh and the series of earthquakes devastating Nias, Central Java and Jogyakarta have become a key element of the WBG's program, anchored around two substantial multi-donor trust funds. The Multi-Donor Fund (MDF) for Aceh and Nias brings together some 15 partners and is providing nearly US\$700 million in resources, while Java Reconstruction Fund (JRF), supported by six partners, brings in an amount close to US\$85 million. Post-disaster reconstruction and recovery in both provinces are progressing well. Following the closure of the Reconstruction and Rehabilitation Agency's (BRR) operations in April 2009, tasked with the reconstruction of Aceh and Nias, the local Government has resumed the authority over the development. As the recovery process progresses, the sustainability of reconstruction investments and promotion of economic development through livelihoods and income generation programs are becoming vital. Both the MDF and JRF are supporting the preparation of new economic development/livelihoods programs. Long term development will also hinge on continuation of peace and stability.

\section{Bank Operations in FY09 and FY10}

Lending. FY09 (July 2008 to June 2009) was marked by a strong lending performance, with 9 projects for US\$4.225 billion, including US\$2 billion in DPL-DDO, a regular DPL and an infrastructure DPL, the National Community Empowerment Program (PNPM) - Urban and Rural, a School Grants Assistance Program (BOS-KITA), a Tax Administration Reform project (PINTAR), a Dam Operations and an Infrastructure Financing Facility. The active portfolio as of end-April comprises 30 projects, including 2 additional financing operations.

In FY10 (July 2009 to June 2010), the WBG expects to deliver 9-10 projects across CPS engagement areas. The base scenario envisages a lending volume in line with that in the CPS of some US\$2.6 billion including DPL6, IDPL3, Urban Water Supply and Java Bali Additional Financing Emergency Reconstruction Project. Other projects expected to be 
delivered in FY10 are projects to enhance medical education, strengthen statistical capacity of the Government, increase youth employment, and expand community development in rural and urban areas, etc.

Analytical and Advisory Services. In addition to the lending program, the WBG is delivering to the Government of Indonesia policy notes and just-in-time advice, technical assistance, as well as reports including a Development Policy Review, a report on Budget Reform (with the IMF), Labor Markets, Health Financing, HIV/AIDs interventions, and a Country Environment Assessment.

In the year ahead the WBG expects to deliver continuing analytical and advisory support, including policy notes and reports for the new Government including on Agriculture and Social Protection, Public Spending, Teacher Management, Low Carbon Growth, Papua Infrastructure Strategy, and Urbanization.

Trust Funds. Trust funds (TF) and grant financing are an integral part of the WBG program. The Indonesian TF portfolio is around US\$1 billion at present. Going forward, knowledge partnerships in delivering on the CPS agenda will become more important.

For questions relating to this annex, contact Bill Wallace, at (+62-21) 5299-3000 or Preeti Ahuja at 202 473-1657 


\section{ANNEX III: INDONESIA-RELATIONS WITH THE ASIAN DEVELOPMENT BANK ${ }^{1}$}

(As of June 12, 2009)

Asian Development Bank (ADB) cumulative loans to Indonesia exceeded $\$ 23.5$ billion at end-December 2008. In 2008, the ADB approved a total of \$1,085 million or 10.3 percent of the total loans approved by the institution for the year. Nonsovereign loans accounted for $\$ 75$ million or 6.7 percent of the total loans. Out of the $\$ 1,010$ million sovereign loans more than 80 percent were provided through three policy-based operations which advanced reforms in macroeconomic management, infrastructure provision, and decentralized public financial management.

In 2006, the ADB Board endorsed the Indonesia Country Strategy and Program (CSP) 2006-2009. The CSP aims to help the government achieve higher levels of pro-poor sustainable growth and to enhance social development, with a key thematic focus on governance and capacity development in all operations. Five areas of engagement were derived to address the main constraints to development: improved infrastructure and infrastructure services, deepened financial sector, improved decentralization, accelerated MDG achievement, and strengthened environment and natural resources management. Since then annual public sector lending and non-lending programs has been agreed with the government selectively focusing on these areas of engagement.

Between 1967 and 2008, ADB provided 499 Technical Assistance grants to Indonesia amounting to $\$ 266.66$ million. The TA grants were financed from ADB's Technical Assistance Special Fund, the Japan Special Fund, and other sources. In 2008, eight TA grants amounting to $\$ 13.0$ million were approved, and represented 4.7 percent of total TA grants approved by ADB during the year.

Table 1. Sovereign and Nonsovereign Loan Approvals and Disbursements to Indonesia

(In millions of U.S. dollars)

\begin{tabular}{lrrrrrr}
\hline & 2003 & 2004 & 2005 & 2006 & 2007 & 2008 \\
\hline Loan approvals & 261.6 & 225.0 & $1,145.69$ & 784.8 & $1,187.1$ & 1,085 \\
Loan disbursement & 442.9 & 593.5 & $1,014.99$ & $1,025.88$ & $1,136.3$ & 949.6 \\
\hline
\end{tabular}

Sources: Asian Development Bank, Annual Report (various editions), and ADB staff.

\footnotetext{
${ }^{1}$ Prepared by ADB staff.
} 
Table 2. Cumulative Lending to Indonesia

(As of December 31, 2008)

\begin{tabular}{lcrr}
\hline \multicolumn{1}{c}{ Sector } & $\begin{array}{c}\text { Loans } \\
\text { (No.) }\end{array}$ & $\begin{array}{c}\text { Amount } \\
(\$ \text { million })\end{array}$ & Percent 1/ \\
\hline Agriculture and Natural Resources & 92 & $3,864.29$ & 16.43 \\
Education & 32 & $2,222.35$ & 9.45 \\
Energy & 31 & $3,781.05$ & 16.07 \\
Finance & 17 & $3,121.10$ & 13.27 \\
Health, Nutrition and Social Protection & 13 & $1,068.30$ & 4.54 \\
Industry and Trade & 13 & 650.70 & 2.77 \\
Law, Economic Management and & 14 & $2,509.22$ & 10.67 \\
Public Policy & & & \\
Multisector & 42 & $3,216.83$ & 13.68 \\
Transport and Communication & 33 & $2,713.86$ & 11.54 \\
Water Supply, Sanitation and & 10 & 375.60 & 1.60 \\
Waste Management & & & \\
Total & 297 & $23,523.30$ & 100.00 \\
\hline
\end{tabular}

Sources: Asian Development Bank, Indonesia Fact Sheet 2009; and ADB staff.

1/ Total may not add up because of rounding. 


\section{ANNEX IV: INDONESIA-STATISTICAL ISSUES ${ }^{1}$}

1. Indonesia's macroeconomic statistics and statistical base are broadly adequate to conduct effective surveillance. Indonesia has been a subscriber to the Special Data Dissemination Standard (SDDS) since September 1996, observing most of the SDDS requirements. Exceptions include the currency composition in the reserve template in the first quarter of 2007, general government data for 2005, and the timeliness in the production index data where short delays have occurred.

\section{Real Sector}

2. The annual national accounts have 2000 as the base year. Quarterly GDP data are published in a timely manner for both expenditure and production sides. The estimates are based on a limited set of indirect indicators of uncertain quality. Some sectors are influenced strongly by seasonality, and seasonally adjusted data are prepared but not published. In addition, no survey of nonfinancial services is prepared. An economic census of businesses is undertaken every 10 years, without updates in the intervening period. The household budget survey does not cover higher income households. There are inconsistencies with the Bank Indonesia (BI) in imports and exports; and, with the Ministry of Finance (MoF) regarding local government figures. The five-yearly input-output tables remove statistical discrepancies, but there are large discrepancies in the intervening years. The Fund has recommended:

(i) development of a system to continuously update the census of businesses; (ii) introduction of comprehensive annual establishment surveys for nonfinancial services industries;

(iii) publication of annual GDP estimates, including a time series of at least 20 years;

(iv) development of a set of annual supply and use tables (SUTS) starting from 2000; and

(v) enhancing the convergence exercise on trade data with $\mathrm{BI}$.

3. Labor market data, including wages and employment, are available, albeit reported with some delay, through the annual labor market survey (Sakernas) published by the Bureau of Statistics. Data on minimum and maximum wages for the formal sector are also available. Quarterly data are available on industrial wages, with some delay.

\section{Public Finance}

4. Available government finance data suffer from a number of weaknesses, in terms of classification, coverage, and timeliness. Data on budgetary central government were available until recently with a one-month lag, but subnational (provincial and local) government data are available only with a lag of two years, and the quality of this data is variable. Problems in

\footnotetext{
${ }^{1}$ The section is based on a detailed assessment of Indonesia's observance of the IMF's Data Quality Assessment Framework, prepared by STA in March 2005.
} 
budget and accounting systems have been compounded by the recent decentralization initiatives, which have shifted substantial resources to the subnational governments. Substantial efforts are in train, and significant progress has been made to overcome these problems, ranging from the planned adoption of advanced accounting and statistical standards, to the introduction of best practice budget management processes, and the development of computerized financial management information systems.

5. Against this background, the MoF and the Ministry of Home Affairs are committed to keeping the requirements of fiscal statistics at the forefront of ongoing fiscal reforms, so as to make better statistical monitoring one of the goals of the current efforts. The coverage and timeliness of public debt statistics is generally adequate; however, only limited information on contingent liabilities is available. The new expenditure classification introduced in the 2005 budget, is generally consistent with the Government Finance Statistics Manual 2001 (GFSM 2001) on functional codes and classification, although the data are compiled on a cash basis.

6. The authorities have committed to adopting GFSM 2001 standards. To this end, the Fund staff has recommended in the short term: (i) establishment of a register of all extrabudgetary units to improve the coverage of central government activity; and (ii) inclusion of the economic codes consistent with the GFSM 2001 in the chart of accounts to ensure that general government units report in a statistically meaningful way all transactions and balances over which they exert control. Over the medium-term, priority should be given to (i) seizing the opportunity offered by the two new subnational fiscal reform efforts to simultaneously establish the underlying reporting arrangements to obtain timely preliminary data for local government statistics; and (ii) to develop GFSM 2001 operating statements, statements of sources and uses of cash, and partial balance sheets, all of which should be published on the MoF websites. ${ }^{2}$

\section{Monetary Accounts}

7. Good quality monetary statistics are compiled by the BI on a timely basis. With STA assistance, BI has developed an integrated database from which alternative presentations of monetary statistics can be drawn to meet the needs of BI and the Fund. Further work, however, is needed to expand the coverage of depository corporations to include mutual funds (REKSA DANA), which report data to BAPEPAM - an agency that supervises some of the nonbank financial institutions. To this end, BI is currently developing institutional data-sharing arrangements that would enable it to access the register of - and data onmutual funds.

\footnotetext{
${ }^{2}$ Local Government Finance and Governance Reform (LGFGR) project.
} 
8. To strengthen monetary statistics, STA missions have recommended: (i) collection of source data on mutual funds in a format that meets statistical requirements; (ii) expansion of the coverage of the monetary statistics to include mutual funds; and (iii) harmonization of the reported interbank positions between the $\mathrm{BI}$ and commercial banks.

\section{Balance of Payments}

9. Trade data are affected by some shortcomings. While customs sources utilized by the $\mathrm{BI}$ are considered generally reliable, coverage of merchandise trade flows is insufficient. Also, when the online reporting system for exports and imports was introduced in 2004, the historical series were reconstructed only as far back as 2003. As a result, prior to 2003 balance of payments statistics are not entirely consistent with the national accounts estimates. Data on services suffer from outdated surveys and weak methodologies. The BI adjusts the customs data to cover exports and imports of Batam and other bonded zones. Data on services suffer from outdated surveys and weak methodology. Adjustments are also made to data on compensation of employees and workers' remittances to cover professional workers, legal workers not reported to the Ministry of Manpower, and illegal workers.

10. For the capital and financial account, the methodological basis for the compilation of FDI data needs substantial improvement. Inflows are currently calculated based on loan disbursements to companies that have foreign equity using a fixed ratio to estimate equity inflows. Surveys conducted by BI to collect FDI data have a low response rate and the coverage of the directory of enterprises should be improved. Other areas that need improvement include the recording of trade credits and the asset data for portfolio investment and other investment transactions. The magnitude of the errors and omissions item has been significant and appears to be related to the methodology used, for instance, for unrecorded assets in the financial account. Financial transactions data have not been reconciled with changes in the International Investment Position (IIP).

11. The BI has proposed a range of measures to address these weaknesses. On traderelated data, a working group has been established to reconcile differences between BI and customs data. The $\mathrm{BI}$ is planning to collect and publish data on goods imported for processing, goods procured in ports by carriers, and transactions with the oil and gas sector. On the financial account, the $\mathrm{BI}$ is planning to collect and publish data on direct investment abroad, portfolio investment assets, other investment assets, and trade credits, to help address the shortcomings in the recording of private financial flows.

\section{International Investment Position}

12. An annual IIP is compiled, but the underlying data are weak in several areas, notably for FDI. External debt statistics have improved considerably with the introduction of an External Debt Information System (EDIS) in 2002. The system records external debt of government and over 800 other entities that report to the BI on a monthly basis. The system 
generates data for public sector external debt and debt service, as well as those for private banks, that are considered reliable. However, improvements are still needed with respect to components of private corporate sector data, particularly in distinguishing between scheduled and actual debt service, in estimating the accumulation/reduction of private sector payments arrears, and in estimating rescheduling and debt reductions received by the private sector from external creditors. 


\section{Indonesia: Table of Common Indicators Required for Surveillance}

(As of June 11, 2009)

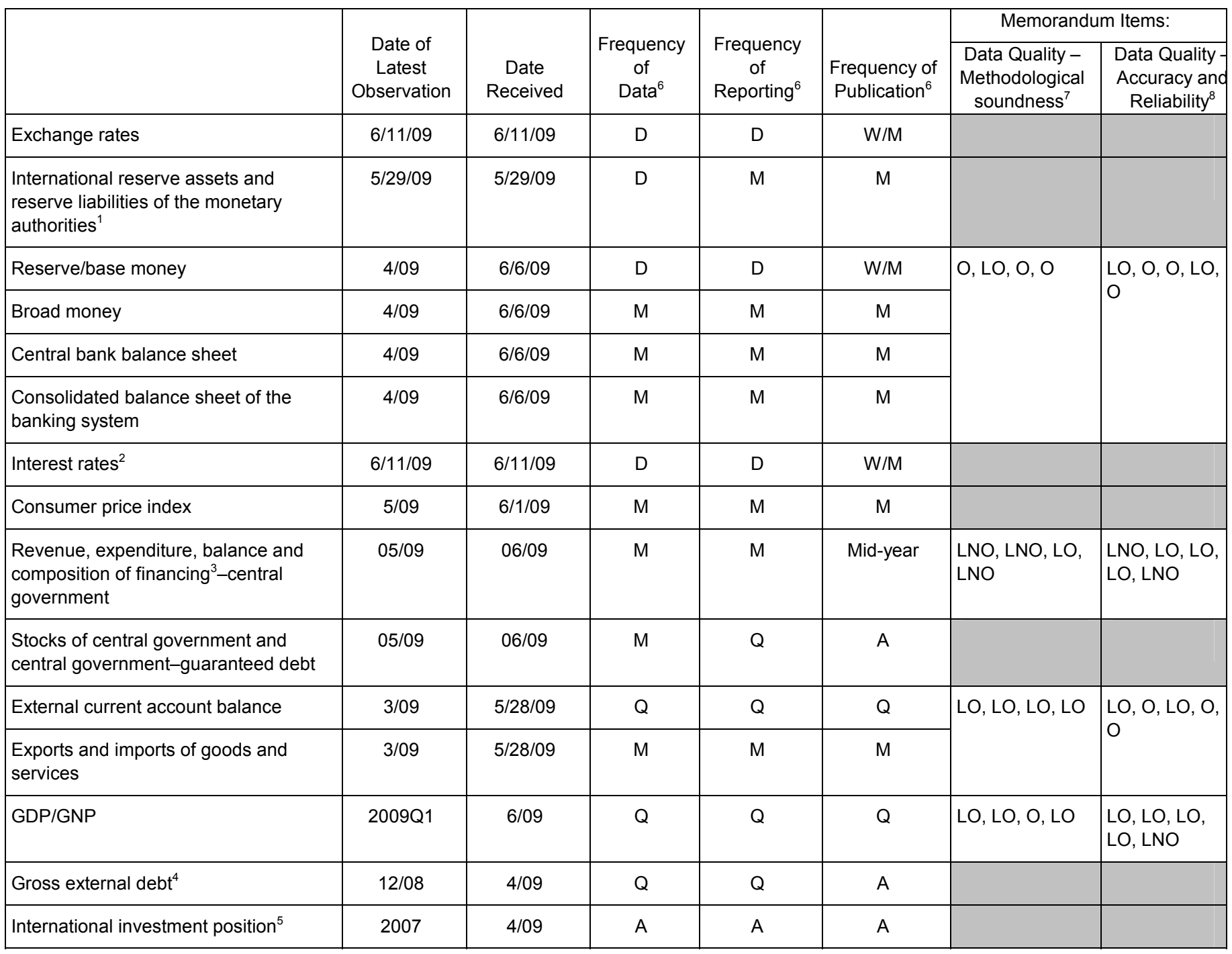

${ }^{1}$ Includes reserve assets pledged or otherwise encumbered as well as net derivative positions.

${ }^{2}$ Both market-based and officially-determined, including discount rates, money market rates, rates on treasury bills, notes and bonds.

${ }^{3}$ Foreign, domestic bank, and domestic nonbank financing.

${ }^{4}$ Including currency and maturity composition.

${ }^{5}$ Includes external gross financial assets and liability positions vis-à-vis non residents.

${ }^{6}$ Daily (D); Weekly (W); Monthly (M); Quarterly (Q); Annually (A); NA: Not Available.

${ }^{7}$ Reflects the assessment provided in the data ROSC published on July 20, 2005 (based on the findings of the mission that took place during March 28-April 11, 2005), for the dataset corresponding to the variable in each row. The assessment indicates whether international standards concerning concepts and definitions, scope, classification/sectorization, and basis for recording are fully observed (O); largely observed (LO); largely not observed (LNO); not observed (NO); and not available (NA).

${ }^{8}$ Same as footnote 7 , except referring to international standards concerning source data, assessment of source data, statistical techniques, assessment and validation of intermediate data and statistical outputs, and revision studies. 


\section{Statement by the IMF Staff Representative on Indonesia July 13, 2009}

1. This statement provides information that has become available since the staff report was circulated to the Executive Board on June 30, 2009. This information does not alter the staff's assessment of policy issues and recommendations contained in the report.

2. Financial markets have been generally quiet in the period leading up to and since the Presidential elections, which were successfully held on July 8 . The official results will be known on July 27. The rupiah/U.S. dollar exchange rate has remained flat so far in July, government bond yields and CDS spreads have been stable, and foreign exchange reserves have remained broadly unchanged.

3. Recent data continue to point to a sustained rebound in economic activity. Leading consumption indicators continued to rise in May, including motor vehicle sales and retail sales, and consumer confidence reached a $4 \frac{1}{2} 2$-year high in June. Moreover, tourist arrivals are also on the rise and have increased by 4 percent in April and May (y/y). Reflecting rising commodity prices, non-oil exports have continued to recover in April and May relative to Q1 of 2009, and imports were also up in May in all groups, including raw materials and capital goods. On an annual basis, however, non-oil exports and imports are still down about 15 percent and 30 percent, respectively.

4. Headline inflation fell to 3.7 percent $(y / y)$ in June, the lowest rate since June 2000. To a large extent, the deceleration reflected the unwinding of base effects (there was a 30 percent fuel price adjustment in late May 2008). Core inflation also slowed, but is still at 5.6 percent. While there may be some upward pressure on food prices as the economy recovers, year-end inflation could potentially finish slightly below the current projection of 5 percent.

5. In line with expectations, Bank Indonesia (BI) reduced the policy rate on July 3 by 25 basis points to 6.75 percent. Consistent with the staff report, BI noted that the room for more easing has become limited due to possible inflation risks in 2010. 


\section{INTERNATIONAL MONETARY FUND}

EXTERNAL

RELATIONS

Public Information Notice

DEPARTMENT

Public Information Notice (PIN) No. 09/93

FOR IMMEDIATE RELEASE

July 28, 2009

International Monetary Fund

$70019^{\text {th }}$ Street, NW

Washington, D. C. 20431 USA

\section{IMF Executive Board Concludes 2009 Article IV Consultation with Indonesia}

On July 13, 2009, the Executive Board of the International Monetary Fund (IMF) concluded the Article IV consultation with Indonesia. ${ }^{1}$

\section{Background}

Indonesia entered the current global crisis with strong initial conditions. Aided by a generally favorable global economic climate that prevailed prior to the recent crisis, Indonesia's fundamentals were strengthened through sound macroeconomic policy implementation, including prudent debt management and developing a sound financial sector. Economic growth averaged about 6 percent since 2005, fiscal performance was strong, the current account was in surplus, both public and external debt dropped to about 30 percent of GDP, and international reserves rose to a relatively comfortable level.

Notwithstanding the initial impact of the global crisis, the economy has rebounded in 2009. During the last quarter of 2008, various factors-falling commodity prices, liquidity problems in some segments of the banking sector, default by a private sector conglomerate on its obligations, and general global risk aversion-led to a sharp deterioration in market conditions. However, with relatively strong corporate and banking sector balance sheet positions, high capitalization and profitability of the banking system, and a series of mitigating policy measures, the economy was able to absorb the impact of the crisis. These factors, combined with the stronger than expected recovery in Q1 of 2009, have boosted domestic and foreign investor confidence.

\footnotetext{
${ }^{1}$ Under Article IV of the IMF's Articles of Agreement, the IMF holds bilateral discussions with members, usually every year. A staff team visits the country, collects economic and financial information, and discusses with officials the country's economic developments and policies. On return to headquarters, the staff prepares a report, which forms the basis for discussion by the Executive Board. At the conclusion of the discussion, the Managing Director, as Chairman of the Board, summarizes the views of Executive Directors, and this summary is transmitted to the country's authorities.
} 
The economy's resilience to the weak global conditions was evident in the stronger than expected GDP growth in Q1 of 2009 that was supported by particularly strong consumption, as private consumption benefited from a large election-related spending stimulus. External accounts also improved in Q1 as the current account was positive from a non-oil trade surplus and the financial account registered a surplus due to demand for sovereign debt securities. CPI inflation has decelerated rapidly since October 2008 reflecting the weaker economic conditions as well as falling commodity prices.

Macroeconomic policy responses have kept appropriate pace with the evolving economic conditions. Bank Indonesia has been on a monetary-easing cycle since December 2008, consistent with lower inflationary pressures and slowing domestic demand. The policy rate has been cut by 275 basis points to $63 / 4$ percent. A fiscal stimulus package of about 1.4 percent of GDP was announced in February 2009. The fiscal space for the stimulus was made possible by solid performance over several years that has resulted in a decline in public debt. Moreover, the flexible exchange rate has served well as an external shock absorber.

Banking and corporate sector indicators are generally robust, and have proved resilient to the crisis. Financial soundness indicators improved in 2008-profitability rose and the capital base strengthened further. Coming from a period of rapid credit growth in the last two years, and in light of the uncertain economic climate, credit expansion has decelerated on a monthly basis since December 2008. Indonesian companies have over time reduced their vulnerabilities, including lowering leverage ratios, raising profitability, and reducing their exposure to external liabilities.

\section{Executive Board Assessment}

Executive Directors welcomed the resilience of the Indonesian economy, which owed much to strong initial fundamentals and appropriate policy responses. Private consumption, supported by the fiscal stimulus package, has kept growth positive and among the highest in the region. The financial sector has recovered from the adverse initial impact of the global turmoil, and investor sentiment has improved in recent months. Nevertheless, Directors noted that, although the economic outlook for 2009 remains positive, another round of global risk aversion could adversely affect external liquidity, demand, and growth prospects for Indonesia. It will therefore be important that the authorities strive to achieve the appropriate policy mix, and promptly adjust it as needed, to preserve macroeconomic and financial stability.

Directors welcomed the fiscal stimulus plan for 2009 and underscored that timely and efficient implementation of the spending program, especially on infrastructure, would be critical to sustaining the economic recovery. They considered it appropriate to maintain some of the stimulus in 2010, given the available fiscal space. While some Directors pointed to financing and capacity constraints, most saw room for a somewhat higher fiscal deficit than currently planned, noting that such a level remains consistent with continued debt consolidation over the medium term, an indication of the authorities' record of fiscal prudence. 
Directors commended the authorities for the progress in fiscal reforms toward a consolidated Treasury Single Account, simplified budget execution procedures, and strengthened cash management. They encouraged the authorities to build on the momentum of past reform efforts to enhance budget flexibility and improve public resource management. Further strengthening tax administration and lowering energy subsidies would help create fiscal space for priority infrastructure and social expenditures.

Directors generally considered that the monetary policy easing since December 2008 was timely and appropriate in the face of decelerating inflation and weakening investment. Going forward, they supported a more cautious stance, given ample liquidity in the banking system, long lags in monetary transmission, and the risk of a reversal of capital flows. Directors encouraged the authorities to continue to strengthen the monetary policy framework. Strong commitment to the medium-term inflation targets, as well as publication of inflation forecasts, would help guide inflation expectations and enhance policy credibility.

Directors stressed that exchange rate flexibility has served the country well in recent months, and remains an important shock absorber. They noted the staff's assessment that the current level of the real effective exchange rate is broadly in line with fundamentals, and that reserves are at a comfortable level. Most Directors considered it prudent nevertheless to build larger reserve buffers gradually over the medium term to preserve investor confidence in the event that global risk aversion deteriorates. Some others believed that the current level of reserves and the various contingency arrangements should provide an adequate cushion.

Directors welcomed the robustness of the banking sector, with banks recording strong capital positions and improved profitability. The crisis management measures recently introduced by Bank Indonesia have helped alleviate liquidity pressures and restore market confidence. Directors looked forward to early parliamentary approval of the Financial Safety Net law, which would help strengthen the legal framework for bank resolution. They emphasized the importance of a further strengthening of the early warning systems, and of continued close supervision of banks, particularly small and medium-sized banks exposed to liquidity risk. Directors looked forward to the forthcoming Financial Sector Assessment Program (FSAP) to help identify priorities for further financial sector reform.

Public Information Notices (PINs) form part of the IMF's efforts to promote transparency of the IMF's views and analysis of economic developments and policies. With the consent of the country (or countries) concerned, PINs are issued after Executive Board discussions of Article IV consultations with member countries, of its surveillance of developments at the regional level, of post-program monitoring, and of ex post assessments of member countries with longer-term program engagements. PINs are also issued after Executive Board discussions of general policy matters, unless otherwise decided by the Executive Board in a particular case. 
Indonesia: Selected Economic Indicators, 2006-10

\begin{tabular}{|c|c|c|c|c|c|}
\hline & 2006 & 2007 & 2008 & 2009 & 2010 \\
\hline & \multicolumn{3}{|c|}{ Actual } & \multicolumn{2}{|c|}{ Projection } \\
\hline Real GDP (percent change) & 5.5 & 6.3 & 6.1 & 3.5 & 4.5 \\
\hline Private consumption & 3.2 & 5.0 & 5.3 & 4.9 & 5.1 \\
\hline Gross fixed investment & 2.6 & 9.4 & 11.7 & 3.2 & 7.6 \\
\hline Net exports $1 /$ & 1.1 & 0.6 & 0.7 & -0.9 & -0.5 \\
\hline \multicolumn{6}{|l|}{ Saving and investment (in percent of GDP) } \\
\hline Gross investment $2 /$ & 24.1 & 25.0 & 27.6 & 26.9 & 27.7 \\
\hline Gross national saving & 27.1 & 27.4 & 27.7 & 27.2 & 27.2 \\
\hline \multicolumn{6}{|l|}{ Prices (12-month percent change, end of period) } \\
\hline Consumer prices (end period) & 6.6 & 5.6 & 11.1 & 5.0 & 5.5 \\
\hline \multicolumn{6}{|l|}{ Public finances (in percent of GDP) } \\
\hline Central government revenue & 18.8 & 17.9 & 19.1 & 15.8 & 15.8 \\
\hline Central government expenditure & 19.7 & 19.1 & 19.2 & 18.4 & 17.8 \\
\hline Central government balance & -1.0 & -1.2 & -0.2 & -2.6 & -2.0 \\
\hline Primary balance & 1.4 & 0.8 & 1.6 & -0.6 & -0.1 \\
\hline Central government debt & 39.0 & 35.1 & 33.2 & 31.1 & 31.0 \\
\hline \multicolumn{6}{|l|}{ Money and credit (12-month percent change; end of period) } \\
\hline Rupiah M2 & 18.0 & 19.5 & 12.6 & $\ldots$ & $\ldots$ \\
\hline Private sector credit & 12.1 & 22.4 & 30.7 & $\ldots$ & $\ldots$ \\
\hline One-month SBI rate (period average) & 11.8 & 8.6 & 9.1 & $\ldots$ & $\ldots$ \\
\hline \multicolumn{6}{|l|}{ Balance of payments (in billions of U.S. dollars) } \\
\hline Non-oil exports (f.o.b) & 80.6 & 93.1 & 107.9 & 80.0 & 81.7 \\
\hline Non-oil imports (f.o.b) & -57.7 & -66.1 & -92.8 & -66.1 & -69.9 \\
\hline Current account balance & 10.9 & 10.5 & 0.3 & 1.4 & -2.4 \\
\hline Overall balance & 14.2 & 12.7 & -5.3 & 10.4 & 3.0 \\
\hline \multicolumn{6}{|l|}{ Gross reserves } \\
\hline In billions of U.S. dollars (end period) & 42.6 & 56.9 & 51.6 & 62.1 & 65.1 \\
\hline In months of imports & 4.7 & 4.7 & 6.0 & 6.8 & 6.5 \\
\hline As a percent of short-term debt $3 /$ & 153.6 & 179.9 & 140.2 & 197.6 & 194.8 \\
\hline \multicolumn{6}{|l|}{ Total external debt } \\
\hline In billions of U.S. dollars & 129.5 & 137.4 & 149.7 & 153.0 & 157.5 \\
\hline In percent of GDP & 35.5 & 31.8 & 29.3 & 29.4 & 27.5 \\
\hline \multicolumn{6}{|l|}{ Exchange rate (period average) } \\
\hline Rupiah per U.S. dollar & 9,165 & 9,141 & 9,439 & $\ldots$ & $\ldots$ \\
\hline Nominal effective exchange rate (Jan. $2000=100$ ) & 83.7 & 80.9 & 73.6 & $\ldots$ & $\ldots$ \\
\hline \multicolumn{6}{|l|}{ Memorandum items: } \\
\hline Nominal GDP (in trillions of rupiah) & 3,339 & 3,957 & 4,954 & 5,413 & 6,015 \\
\hline Nominal GDP (in billions of U.S. dollars) & 364 & 433 & 512 & 520 & 572 \\
\hline
\end{tabular}

Sources: Data provided by the Indonesian authorities; and IMF staff estimates.

1/ Contribution to GDP growth (percentage points).

$2 /$ Includes changes in stocks.

3 / Short-term debt on a remaining maturity basis. 


\section{Statement by Duangmanee Vongpradhip, Executive Director for Indonesia and Dicky Kartikoyono, Senior Advisor to Executive Director July 13, 2009}

\section{Introduction}

On behalf of our Indonesian authorities, we would like to express our gratitude to the mission team for the constructive discussion during their recent visit. Our Indonesian authorities value this year's Article IV consultation during a time when the global economy is undergoing a severe economic strain. The staff report provides a balanced and clear overview of key recent economic developments and the challenges facing Indonesia and so many other member countries. Overall, they broadly agree with the staff appraisal and appreciate their policy recommendations going forward.

\section{Recent Economic Developments}

After several years of strong and sustained economic growth, Indonesia now faces the challenge to maintain the hard-earned macroeconomic stability and to keep advancing towards higher economic and social developments. The substantial waning in commodity prices, slackening global demand and trade began to bear down on the Indonesian economy since the fourth quarter of 2008. The global financial strain has also put pressures on domestic financial markets, with banks finding it harder to secure external financing, as well as exporters to obtain favorable trade financing. The heightened uncertainty has signaled both portfolio and real sector investors to be more observant in revolving their investment or considering their new commitment.

Nevertheless, in relative terms, Indonesia's overall position is not as precarious as for many other countries. With its less interconnectedness on global capital, robust private consumption, and better exports performance, Indonesia's slowdown has come relatively later and been more moderate than for many countries. Along with stronger macroeconomic policy framework and credibility, the authorities have been able to weather the current crisis from a better position than in the past. This achievement has been recognized by Moody's, which has changed the outlook for Indonesia's Ba3 sovereign rating from stable to positive last month.

The budget performance in fiscal year of 2008/2009 was remarkable. Budget deficit was just 0.1 percent of GDP, compared with 2.1 percent projected earlier in 2008 when global oil prices and the Indonesia's energy subsidies rose to their peak. Revenue was about 10 percent above budgeted level, due to high commodity prices and improvements in tax office administration, while underspending continued as it had in recent years. Despite the exchange rate depreciation, the debt to GDP ratio declined significantly to 33 percent at yearend. This prudent fiscal management has allowed our authorities to adopt countercyclical macroeconomic policies for stabilizing the external and internal balances. The authorities were able to take early action in providing pertinent economic stimulus. The immediate task was to restore confidence and maintain aggregate demand. Coverage of deposit guarantee was increased, interest rate was lowered, and the real economy was stimulated by fiscal 
expansion. Meanwhile, the unprecedented spending associated with the general parliamentary election process in the first quarter of 2009 was substantially playing out to resist further retrenchment in economic growth. The vibrant democratic process was apparently reflected in the high growth of the election-related-sub sectors, such as advertising, telecommunication, transportation, hotel, restaurant, printing and textile industry.

Both fundamental policy responses and a temporary event turned out to be effective in cushioning in the economy from further deterioration. In tandem, Indonesia GDP growth just stalled to 4.4 percent (year-on-year) in the first quarter of 2009 from 6.1 percent in 2008 , while it slowed even more severe in most other economies. The subsequent presidential election process, which will be held on July 8, with the fall back second round ending in September 2009, is also expected to sustain demand and economic activity.

After hiking sharply in the first three quarters of 2008, fuelled primarily by soaring global oil and food prices, CPI inflation came down in response to the continued weakening in the economy as well as the deflationary trend in trading partner nations and improvement in supply of food stuffs. Bank Indonesia has responded to the ups and downs of the global trend with an abrupt shift in directions of monetary policy. It raised its policy rate from 8 percent in May to 9.5 percent in October 2008 during the mounting inflationary pressures. On the reverse trend, policy rate was cut in each of eight consecutive months from December 2008 to July 2009 by a total of 275 basis points, when the authorities has allowed lower global prices to pass through to administered prices.

On external position, Indonesia, as an open economy, is obviously in no position to isolate itself from the global malaise, despite having developed considerable growth momentum. The fallout of the global financial crisis in the second half of 2008 has suddenly reversed the Indonesia's balance of payments performance, after benefiting from buoyant volume of exports and strong commodity prices in the first half of 2008. Foreign portfolio investors rushed to pull their existing holdings of financial assets out of Indonesia's market. These events led to heavy pressure on the Rupiah and sharply increased its volatility. The Rupiah depreciated more than 15 percent during the last quarter of 2008. Also, exports began tapering off in response to falling commodity prices and declining economic activity in trading partner countries. The combined deficits in the current account and the capital account contributed to a surging balance of payments deficit of USD 4.2 billion in the final quarter of 2008. International reserves declined by close to USD 8 billion from its comfortable level of USD 59.4 billion in the first half of 2008 to USD 51.6 billion at the end of 2008. Indonesia's balance of payments, however, regained its traction in the first quarter of 2009 with overall balance charting a surplus of nearly USD 4 billion and international reserves escalating to USD 54.8 billion (equivalent to 5.9 months of imports and official debt repayment). This was due to increased capital inflows from government bond issuance and foreign portfolio investment.

On the banking sector front, following rapid credit expansion of 29.5 percent in 2008, bank lending has started to decline as the economic slowdown impaired supply and demand of credit. Banks have become more cautious and perceived higher credit risk in their lending activities by applying stricter loan standard. Furthermore, customers have been reluctant to 
expand their business and production as the global slowdown has affected both domestic and external demand. This development coupled with increased required provisioning because of worsening quality of the loan may lower bank profitability. Despite this challenge, Capital Adequacy Ratio (CAR) is expected to remain high about 18 percent and Non Performing Loan (NPL) remaining below 5 percent in 2009 with over 100 percent loan loss coverage. The Indonesian banking sector thus continues to be healthy and robust.

\section{Prospects and Policies Direction}

Over 2009 and 2010, our authorities remain cautious of the downside risks of growing uncertainty, weakening global demand, and limited sources of financing, should the heightened global economic slowdown prolonged beyond expectation. They are fully cognizant that the global crisis will result in Indonesia's slackening GDP growth and exacerbating the already decreasing export performance. A range of the policies taken under crisis response initiatives, including unconventional steps, has done much to stabilize the economy during the global downturn. Our authorities are determined to make every effort to minimize the impact of the crisis, and to take measures to strike a balance between three strategic aspects: namely, monetary stability, strengthening financial system stability, and aligning stimuli to maintain economic growth momentum.

\section{Fiscal Policy}

On fiscal policy, our authorities have formulated the revised budget with a stimulus package amounted to USD 7.1 billion, which constitutes a range of tax cut, provision of subsidies for medication and cooking oil, pay increases for civil servants, provision of direct cash transfers and expenditures for community block grants. The expectation is to maintain the level of strong domestic demand in the first quarter of 2009 so as to adequately compensate for the anticipated deterioration in income and exports. Our authorities are aware that the execution capacity of the fiscal stimulus, both by the central and regional government, will be crucial to preventing a sharp drop in domestic demand. Hence, they have taken extraordinary efforts to expedite the budget execution process, particularly for regional government, in a right and timely fashion. These measures are therefore expected to be able to secure the public purchasing power and continue the level of first quarter GDP growth of 4.4 percent to the rest of 2009.

Going forward, the government is vigilant that the flagging economy would affect budget revenue, including tax revenue, dividends of State Owned Enterprises and oil \& gas revenue. On the other hand, they are compelled to ramp up their expenditures allocation for undertaking various counter cyclical policies. At the current juncture, the government has secured a parliamentary approval to revise its budget by increasing the deficit to 2.5 percent of GDP, from 1.0 percent in the original budget.

Nonetheless, it is acknowledged that an expansionary budget always brings a considerable risk in secure financing resources, especially with short supply of global liquidity. As a 
prudent and precautionary step in such a case, and to safeguard market confidence, during the first quarter of 2009, the authorities sold 3.5 billion dollar denominated bonds, and USD 650 million global Islamic Bond. These have boosted international reserves up to USD 57.9 billion. Furthermore, the government has engaged in intensive talks with development partners to provide back up in the form of standby loans, should it not be possible to access the financial market on reasonable terms. So far, several creditors' commitment has been granted to guarantee standby loans amounting to USD 5.5 billion, including the Asian Development Bank (ADB), the World Bank (WB), Australia and Japan, in the form of guarantee for a samurai bond issuance.

\section{Monetary Policy}

On monetary policies, Bank Indonesia's heightened alertness to strike an optimum balance in maintaining price stability while providing an effective monetary stimulus to the real sector has proven to be timely and effective. CPI inflation in 2009 is projected to continue on a downward trend in response to a very good harvest season, the still weakened condition of the domestic economy, low inflation in trading partner nations and improvement in supply of foods. After eight consecutive cuts since December 2008, the policy rate of 6.75 percent is now predicted to approach its bottom. Inflation for 2009 is expected to be at the lower end of the 5-7 percent projection.

The downward trend of the BI Rate has also met with positive response in the banking system, albeit on a limited scale. Since December 2008, bank deposit rates have come down 150 bps in response to cuts in the BI Rate. Over the same period, loan interest rates eased by an aggregate $100 \mathrm{bps}$, while the expansion of bank lending has just started to show its early sign of recovery. In this connection, Bank Indonesia has a strong commitment to strengthen the effectiveness of its public communication to address the weakened monetary policy transmission through banks deposit and lending rates. Be that as it may, with the spurred optimism of business sector post the election process, credit growth would likely be at its faster pace in the second quarter of 2009.

\section{External Position and Exchange Rate Development}

Like in many other economies, the weaker global growth in 2009 will put heavy challenges to the Indonesia's external position. Indonesia's exports will vary with the development in global commodity prices, while both the value and quantity of imports will drop, at least as swiftly as the plunge in exports. The rate of decline in imports may reach a trough due to the weakening domestic demand and sluggish international trade.

As a result, the authorities are aware of the risk of a minor current account deficit, though the prospect of maintaining current account surplus remains open with the rebound of global commodity prices and improved demand from emerging markets. In the capital and financial account, the continuing consolidations on global financial markets will slowdown capital inflows to Indonesia. Inflows from government's financing and foreign direct investment will balance the impact and positive perception on domestic economy will help improve portfolio inflows. 
The extent of the recovery of global financial markets will likely be key to performance in the Indonesia capital and financial account. Meanwhile, disbursement on external debt and issuance of government global bond will affect the magnitude of capital movement of Indonesian financial assets, which will eventually influence the Rupiah stability. Bearing this in mind, our authorities have enacted preemptive steps to call on foreign reserves under various bilateral and multilateral swap arrangements. They have access to bilateral currency swap arrangement with China amounted to RMB 100 billion (equivalent to USD 15 billion) as well as bilateral swap arrangement with Japan, China and Korea totalling USD 18 billion. Also, they have worked closely with the ASEAN+ 3 partners to speed up the implementation of the Chiang Mai Initiative Multilaterisation (of which Indonesia's access amounted to USD 11.925 billion). To date, none of these facilities has been withdrawn, as Indonesia's international reserves remain steady at the adequate level.

This was followed by a temporary measure to safeguard the supply of foreign currency in the domestic market in order to maintain exchange rate stability during mounting uncertainty. Under this temporary regulation, banks may avail a USD repurchase agreement with Bank Indonesia. They can bring their Indonesian Government foreign currency denominated bond to Bank Indonesia to be exchanged with foreign currency in repo transactions for tenors of 1 month.

Hence, since April 2009, all the abovementioned factors have contributed to the Rupiah stabilizing below 10.500 per USD, after depreciating gradually around $11.000-12.000$ per USD in the last 6 months.

\section{The Financial Sector Development}

Recent aggregate financial indicators suggest that Indonesia's financial sector remains sound and healthy. In April 2009, overall bank capital adequacy ratio (CAR) was 17.6 percent, while the gross non-performing loans (NPLs) ratio has been held steadily at around 4 percent, a far cry from levels seen during the Asian crisis. Liquidity in the banking system, including the inter-bank money market, has also progressively improved alongside growth in depositor funds. Meanwhile, on the financial market, capital inflows have been driven by positive sentiment in the stabilized global economic activity. This in turn has led to an appreciation of the Rupiah, a renewed growth in the composite stock index and an improvement in yield on Indonesian Government Securities. The Credit Default Swap (CDS) spread for Indonesia, as an indicator of risk perceptions, also eased from $403 \mathrm{bps}$ at end-April 2009 to about 333 bps at end-May 2009.

On banking policy, the authorities continued to promulgate regulations and policies with prudential principles but providing enough room for bank intermediation and business financing through the capital market and other non-bank financial institutions. Improved coordination between Bank Indonesia and the Government under the new Financial Safety Net framework has improved surveillance quality in the banking sector and non-bank financial institutions as well as the capital market. The expeditious takeover of a mid-size problem bank by the Government during the peak of global crisis and the closure of a small 
problem bank in April 2009 by Bank Indonesia have resulted in strengthened public confidence in the banking system. Furthermore, discipline when implementing prudent regulations succeeded in limiting Indonesian banks' exposure to larger problems associated with derivative products, as faced by a number of other developing and developed countries.

Going forward, the authorities have committed to improve capital market and banking system resiliency by enacting several strategic initiatives. Their immediate priority is to promote banks efficiency and roles in expanding financial services, while continuing to strengthen their supervisory framework. These initiatives call for simplifying the administrative burdens of the system, along with ongoing close monitoring to point out potential problems. Coupled with regular stress test to evaluate vulnerabilities, prompt and corrective actions in handling problems are essential to confine further deterioration in the system. 